\title{
Encapsulation of tricopper cluster in a protein-like cavitand enables facile redox processes from $\mathrm{Cu}^{\prime} \mathrm{Cu}^{\prime} \mathrm{Cu}$ to $\mathrm{Cu}^{\prime \prime} \mathrm{Cu}^{\prime \prime} \mathrm{Cu}^{\prime \prime}$ states
}

\author{
Weiyao Zhang, ${ }^{\dagger}$ Curtis E. Moore, ${ }^{\dagger}$ and Shiyu Zhang*,† \\ ${ }^{\dagger}$ Department of Chemistry \& Biochemistry, The Ohio State University, 100 West $18^{\text {th }}$ Avenue, Columbus, Ohio 43210 , \\ United States
}

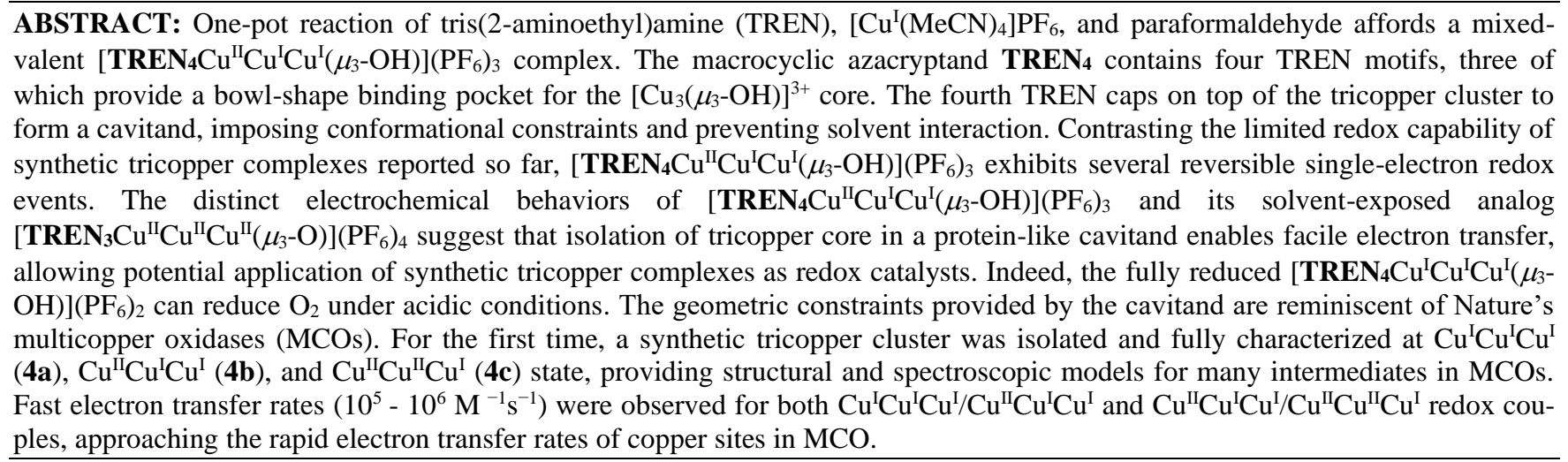

\section{INTRODUCTION}

Synthetic tricopper clusters have been a prominent synthetic target for (bio)inorganic community over the past few decades, ${ }^{1-9}$ since tricopper centers were identified/proposed as essential active sites for biological reduction of $\mathrm{O}_{2}$ to $\mathrm{H}_{2} \mathrm{O}$ in multicopper oxidase (MCO) $)^{10,11}$ and aerobic hydroxylation of methane in particulate methane monooxygenase (pMMO).$^{12}$ Although a tricopper active site in pMMO has been disputed, the conversion of methane to methanol was demonstrated with small-molecule tricopper complexes. ${ }^{13,14}$ In both oxygen reduction and hydrocarbon hydroxylation, the synergy of three $\mathrm{Cu}^{\mathrm{II}} / \mathrm{Cu}^{\mathrm{I}}$ redox couples in tricopper clusters is essential to harness the oxidative power of $\mathrm{O}_{2}$. Therefore, understanding factors governing the redox of tricopper clusters as a single unit is fundamental to their development as biomimetic catalysts in fuel cell technology and functionalization of alkanes.

An ideal tricopper redox catalyst should be able to engage all three $\mathrm{Cu}^{\mathrm{II}} / \mathrm{Cu}^{\mathrm{I}}$ couple and accommodate four redox states from $\mathrm{Cu}^{\mathrm{I}} \mathrm{Cu}^{\mathrm{I}} \mathrm{Cu}^{\mathrm{I}}$ to $\mathrm{Cu}^{\mathrm{II}} \mathrm{Cu}^{\mathrm{II}} \mathrm{Cu}^{\mathrm{II}}$. However, the majority of synthetic tricopper clusters reported to date have limited redox capability, and only isolated at a single oxidation state (primarily $\mathrm{Cu}^{\mathrm{II}} \mathrm{Cu}^{\mathrm{II}} \mathrm{Cu}^{\mathrm{II}}$ or $\left.\mathrm{Cu}^{\mathrm{I}} \mathrm{Cu}^{\mathrm{I}} \mathrm{Cu}^{\mathrm{I}}\right){ }^{15,16}$ Copper(I) center $\left(\mathrm{d}^{10}\right)$ and copper(II) center $\left(\mathrm{d}_{9}\right)$ prefer distinct geometry due to the Jahn-Teller effect. The redox of $\mathrm{Cu}^{\mathrm{II}} / \mathrm{Cu}^{\mathrm{I}}$, in an unconstrained solvent-exposed environment, often results in significant geometric rearrangement associated with high reorganization energy. ${ }^{17}$ Notably, among $c a .186$ crystallographically characterized molecular tricopper $\mu_{3}-\mathrm{E},(\mathrm{E}=\mathrm{O}, \mathrm{OH}, \mathrm{S})$ clusters, $\mathbf{1}$ and $\mathbf{2}$
A

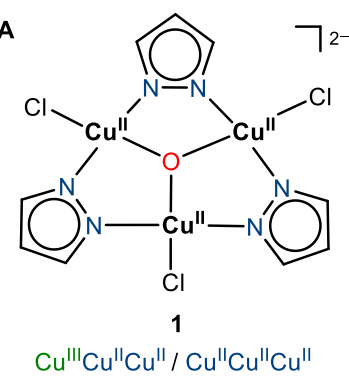

Raptis 2002

C

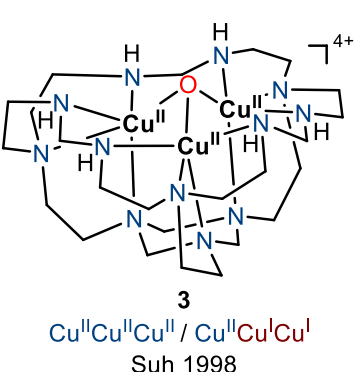
Suh 1998

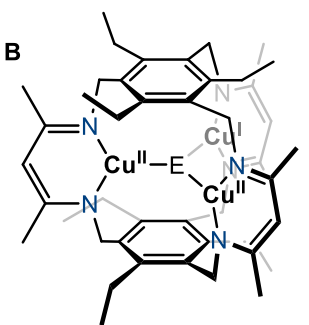

2, $E=O, S, S e$ $\mathrm{Cu}^{\prime \prime} \mathrm{Cu}$ "Cu"l / Cu" Cu" Cul Murray 2018

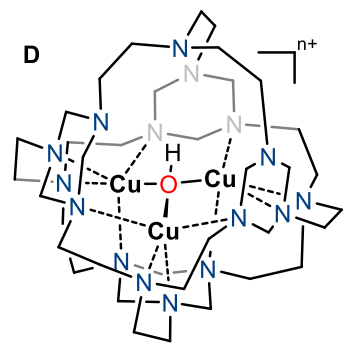

$4 a, n=2 ; 4 b, n=3 ; 4 c, n=4$; $\mathrm{Cu}^{\prime \prime} \mathrm{Cu}^{\prime \prime} \mathrm{Cu}{ }^{\prime \prime} / \mathrm{Cu}^{\prime \prime} \mathrm{Cu}{ }^{\prime \prime} \mathrm{Cu}{ }^{\prime}$ $\mathrm{Cu}{ }^{\prime \prime} \mathrm{Cu}^{\prime} \mathrm{Cu}^{\prime} / \mathrm{Cu}^{\prime} \mathrm{Cu}^{\prime} \mathrm{Cu}{ }^{\prime}$

This work

Figure 1. Redox-active tricopper clusters and their corresponding oxidation states demonstrated by cyclic voltammetry. Complex 4 reported in this work was isolated and characterized at three different oxidation states, denoted as $4 \mathbf{a}\left(\mathrm{Cu}^{\mathrm{I}-}\right.$ $\left.\mathrm{Cu}^{\mathrm{I}} \mathrm{Cu}^{\mathrm{I}}\right), 4 \mathbf{b}\left(\mathrm{Cu}^{\mathrm{II}} \mathrm{Cu}^{\mathrm{I}} \mathrm{Cu}^{\mathrm{I}}\right)$, and $4 \mathbf{c}\left(\mathrm{Cu}^{\mathrm{II}} \mathrm{Cu}^{\mathrm{II}} \mathrm{Cu}^{\mathrm{I}}\right)$. 
(Figure 1A, 1B) represents the only two redox-active examples. ${ }^{18,19}$ Even 1 and 2, however, cannot be further reduced to the $\mathrm{Cu}^{\mathrm{I}} \mathrm{Cu}^{\mathrm{I}} \mathrm{Cu}^{\mathrm{I}}$ state, ${ }^{16}$ which is crucial for the activation of $\mathrm{O}_{2}$ during catalytic oxygen reduction reaction (ORR) and hydrocarbon hydroxylation. In sharp contrast, Nature's trinuclear copper cluster (TNC) in MCOs has been observed in three different oxidation states: fully reduced $\left(\mathrm{Cu}^{\mathrm{I}} \mathrm{Cu}^{\mathrm{I}} \mathrm{Cu}^{\mathrm{I}}, \mathrm{FR}\right)$, alternative resting $\left(\mathrm{Cu}^{\mathrm{II}} \mathrm{Cu}^{\mathrm{I}} \mathrm{Cu}^{\mathrm{I}}, \mathrm{AR}\right)$, and native intermediate $\left(\mathrm{Cu}^{\mathrm{II}} \mathrm{Cu}^{\mathrm{II}} \mathrm{Cu}^{\mathrm{II}}, \mathrm{NI}\right)$. Unlike synthetic tricopper complexes, TNC is embedded in a protein matrix, which provides conformational strains and site isolation that reduce reorganization energy during electron transfer (ET). ${ }^{20,21}$

According to Marcus theory, electron transfer in solution is strongly influenced by both inner sphere ligand interactions and outer sphere solvent environments. ${ }^{17} \mathrm{We}$ posited that the encapsulation of synthetic tricopper center in a protein-like cavitand could constrain the coordination environment, hence lowing the barriers for reorganization and allowing access to different redox states of tricopper clusters. Instead of using bulky ligands to simulate the protein environment, we leveraged multicyclic azacryptand ligand to restrict the conformational freedom and limit solvent interaction. The electrochemical property of $\mathbf{4}$ was compared to their solvent-exposed ana$\log \left[\mathbf{T R E N} \mathbf{C u}_{3} \mathrm{Cu}^{\mathrm{II}} \mathrm{Cu}^{\mathrm{II}} \mathrm{Cu}^{\mathrm{II}}\left(\mu_{3}-\mathrm{O}\right)\right]\left(\mathrm{PF}_{6}\right)_{4}, \mathbf{3}^{22}$ to understand how compartmentalization of tricopper center impacts the redox behavior of $\mathrm{Cu}^{\mathrm{II}} / \mathrm{Cu}^{\mathrm{I}}$.

\section{RESULTS AND DISCUSSION}

Synthesis and characterization of encapsulated tricopper complex, [TREN $\left.\mathrm{Tu}_{4}{ }^{\mathrm{II}} \mathrm{Cu}^{\mathrm{I}} \mathrm{Cu}^{\mathrm{I}}\left(\mu_{3}-\mathrm{OH}\right)\right]\left(\mathrm{PF}_{6}\right)_{3}$, 4b. Tricopper complex [TREN $\left.{ }_{3} \mathrm{Cu}^{\mathrm{II}} \mathrm{Cu}^{\mathrm{II}} \mathrm{Cu}^{\mathrm{II}}\left(\mu_{3}-\mathrm{O}\right)\right]\left(\mathrm{PF}_{6}\right)_{4}, 3$ (Figure 1C) has been considered as a structural ${ }^{22}$ and spectroscopic model ${ }^{23,24}$ for TNC. However, 3 do not exhibit the multi-electron redox function of TNC. The ca. $550 \mathrm{mV}$ separation of the redox couple (see supporting information), which is typical for synthetic tricopper complexes, indicates a substantial barrier for
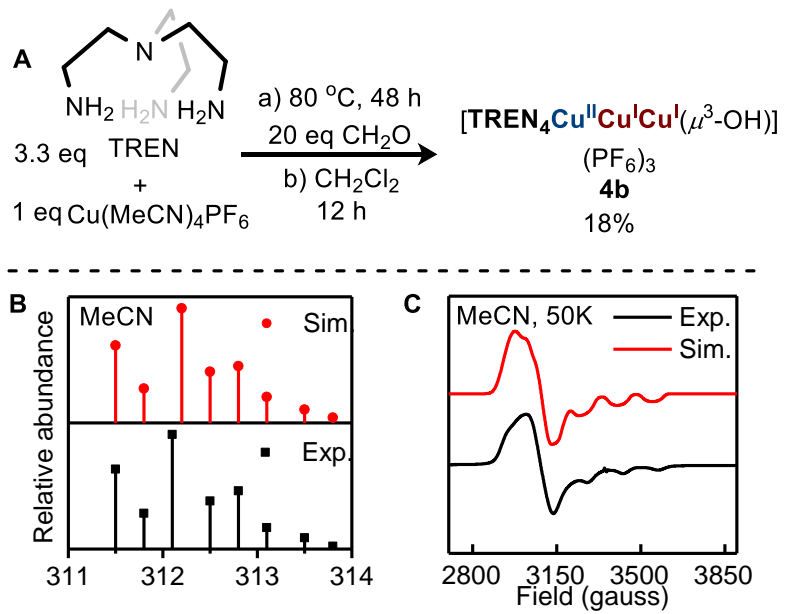

Figure 2. (A) Synthesis of $\left[\mathbf{T R E N}_{4} \mathrm{Cu}^{\mathrm{II}} \mathrm{Cu}^{\mathrm{I}} \mathrm{Cu}^{\mathrm{I}}\left(\mu_{3}-\mathrm{OH}\right)\right]\left(\mathrm{PF}_{6}\right)_{3}$ (4b). (B) ESI-MS (positive mode) of $\mathbf{4 b}$, (C) X-band EPR spectrum (frozen $\mathrm{MeCN}, 0.5 \mathrm{mM}$ ) of $\mathbf{4 b}, \mathrm{g}_{\mathrm{x}}=2.25 \mathrm{~g}_{\mathrm{y}}=2.14$, $\mathrm{g}_{\mathrm{z}}=2.01, \mathrm{~A}_{\mathrm{z}}(\mathrm{Cu})=146 \mathrm{MHz}$. reorganization during ET. Notably, the reduction of $\mathrm{Cu}^{\mathrm{II}} \mathrm{Cu}^{\mathrm{I}-}$ $\mathrm{Cu}^{\mathrm{I}}$ to $\mathrm{Cu}^{\mathrm{I}} \mathrm{Cu}^{\mathrm{I}} \mathrm{Cu}^{\mathrm{I}}$ was not observed within the voltage window of water, suggesting $\mathbf{3}$ is not suitable to activate dioxygen. To construct a protein-like environment, we sought to install an additional TREN cap on 3 to afford $\mathbf{4}$ (Figure 1D). The desired azacryptand ligand TREN 4 has synthesized previously, ${ }^{25}$ however, no transition metal complex has been reported thus far. We found that metalation of $\mathbf{T R E N}_{4}$ with $\mathrm{Cu}(\mathrm{I})$ and $\mathrm{Cu}(\mathrm{II})$ salts only afforded complicated mixtures in low yields. Inspired by the metal-templated synthesis reported by Suh et. al., ${ }^{22}$ we explored the one-pot reaction of copper salts, TREN, and paraformaldehyde. Reaction of $\left[\mathrm{Cu}^{\mathrm{I}}(\mathrm{MeCN})_{4}\right] \mathrm{PF}_{6}$, TREN (3.3 equivalents), and paraformaldehyde (20 equivalents based on $\mathrm{CH}_{2} \mathrm{O}$ units) resulted in the formation of a blue solid (Figure $2 \mathrm{~A}$ ). Workup and recrystallization under our optimized conditions afforded complex $\mathbf{4 b}$ in $18 \%$ yield (see supporting information).

The Electrospray Ionization Mass Spectrum (ESI-MS, Figure $2 \mathrm{~B}$ ) of $\mathbf{4 b}$ exhibited a prominent peak at $312.2 \mathrm{~m} / \mathrm{z}$, and the isotope distribution pattern matches that of $\left[\text { TREN }{ }_{4} \mathrm{Cu}^{\mathrm{II}} \mathrm{Cu}^{\mathrm{I}} \mathrm{Cu}^{\mathrm{I}}\left(\mu_{3}-\mathrm{OH}\right)\right]^{3+} \quad$ (molecular mass $=938.75$ $\left.\mathrm{g} / \mathrm{mol}, \mathrm{C}_{36} \mathrm{H}_{75} \mathrm{Cu}_{3} \mathrm{~N}_{16} \mathrm{O}\right)$, supporting the presence of a $\left[\mathrm{Cu}_{3}\left(\mu_{3^{-}}\right.\right.$ $\mathrm{OH})]^{3+}$ core. The frozen solution electron paramagnetic resonance (EPR) spectrum of $\mathbf{4 b}$ (Figure 2C) displayed a rhombic signal $\left(g_{x}=2.25, g_{y}=2.14, g_{z}=2.01\right)$ with hyperfine couplings to one ${ }^{63 / 65} \mathrm{Cu}(I=3 / 2)$ nucleus $\left(A_{z}(C u)=146 \mathrm{MHz}\right)$, suggesting a valence-localized one-hole $\mathrm{Cu}^{\mathrm{II}} \mathrm{Cu}^{\mathrm{I}} \mathrm{Cu}^{\mathrm{I}}$ electronic structure. The high $g_{x}$ and $g_{y}$ values indicated that the unpaired electron resides in the $d_{z 2}$ orbital, consistent with a trigonal bipyramidal geometry. ${ }^{26}$

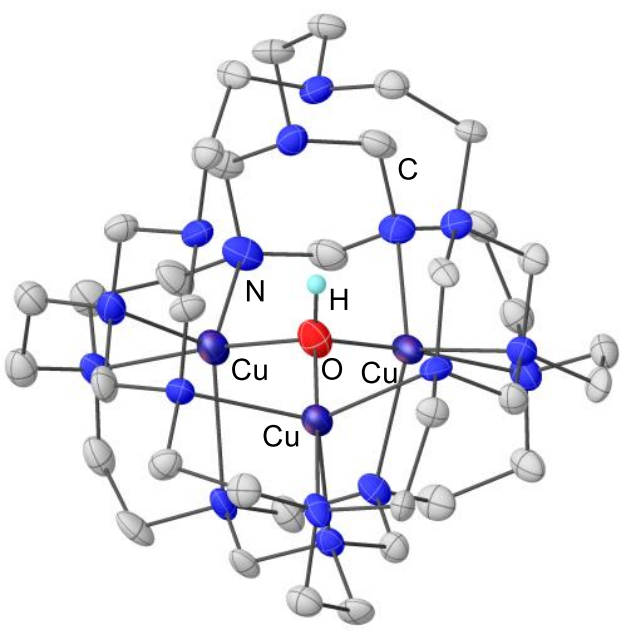

Figure 3. Solid-state structure of $\mathbf{4 b}(100 \mathrm{~K})$ with thermal ellipsoids shown at $35 \%$ probability level. All $\mathrm{PF}_{6}$ anions, the minor components of disorder, and all $\mathrm{C}-\mathrm{H}$ hydrogen atoms are omitted for clarity.

Single crystal X-ray diffraction analysis of $\mathbf{4 b}$ confirmed its assignment as mixed-valent $\left[\right.$ TREN $\left.{ }_{4} \mathrm{Cu}^{\mathrm{II}} \mathrm{Cu}^{\mathrm{I}} \mathrm{Cu}^{\mathrm{I}}\left(\mu_{3}-\mathrm{OH}\right)\right]\left(\mathrm{PF}_{6}\right)_{3}$ (Figure 3). Cryptate $\mathbf{4 b}$ shares the macrocyclic tricopper assembly of $\mathbf{3}$ but features a fully encapsulated tricopper core. Three of four TREN moieties in TREN 4 serve as bowl-shape binding sites for the tricopper core, while the remaining one 
forms a cavitand that isolates the $\mathrm{Cu}_{3}\left(\mu_{3}-\mathrm{OH}\right)$ core in a protein-like capsule. With its one-hole $\mathrm{Cu}^{\mathrm{II}} \mathrm{Cu}^{\mathrm{I}} \mathrm{Cu}^{\mathrm{I}}$ oxidation state, complex $\mathbf{4 b}$ is the first synthetic model for the alternative resting (AR) state in $\mathrm{MCO}\left(\mathrm{Cu}^{\mathrm{II}} \mathrm{Cu}^{\mathrm{I}} \mathrm{Cu}^{\mathrm{I}}\right){ }^{27,28} \mathrm{The} \mathrm{Cu}{ }^{\cdots} \mathrm{Cu}$ and $\mathrm{Cu}-$ $\mathrm{O}$ bond metrics within 4b $\left(\mathrm{Cu}^{\cdots} \mathrm{Cu}\right.$ : 2.973-3.260 $\AA$; $\mathrm{Cu}-\mathrm{O}$ : 1.878-1.971 $\AA$ ) are similar to those in $3(\mathrm{Cu} \cdots \mathrm{Cu}: 3.095 \AA$; $\mathrm{Cu}-$ O: $1.863 \AA$ ) but vary greater from each other, perhaps as a result of its localized electronic structure.

Electrochemical study of $\mathbf{4 b}$ and 3. To evaluate the impact of tricopper encapsulation on the redox capability, we performed cyclic voltammetry (CV) studies of $\mathbf{3}$ and $\mathbf{4}$ in aqueous environments with $\mathrm{pH}$ values range from 5.6 to 13 . Dissolution of $\mathbf{3}$ in water produces an equilibrium mixture of $\mathbf{3}$ and its conjugate acid $(\mathrm{pKa}=4.6){ }^{22}$ Cyclic voltammogram of 3 at $\mathrm{pH}$ $=5.6$ showed an irreversible reduction at $-0.18 \mathrm{~V}$ (vs. NHE), which gradually shifts to $-0.30 \mathrm{~V}$ (vs. NHE) at $\mathrm{pH}=13$. This cathodic peak is assigned to the two-electron reduction of $\left[\mathrm{Cu}^{\mathrm{II}} \mathrm{Cu}^{\mathrm{II}} \mathrm{Cu}^{\mathrm{II}}\left(\mu_{3}-\mathrm{OH}\right)\right]^{5+}$ to $\left[\mathrm{Cu}^{\mathrm{II}} \mathrm{Cu}^{\mathrm{I}} \mathrm{Cu}^{\mathrm{I}}\left(\mu_{3}-\mathrm{OH}\right)\right]^{3+}$ based on variable scan rate $\mathrm{CV}$ study (see supporting information, Figure S19). During the reverse scan, an anodic peak was observed at $0.37 \mathrm{~V}$ (vs. NHE, $\mathrm{pH}=5.8$ ), which is attributed to the oxidation of $\left[\mathrm{Cu}^{\mathrm{II}} \mathrm{Cu}^{\mathrm{I}} \mathrm{Cu}^{\mathrm{I}}\left(\mu_{3}-\mathrm{OH}\right)\right]^{3+}$ back to $\left[\mathrm{Cu}^{\mathrm{II}} \mathrm{Cu}{ }^{\mathrm{II}} \mathrm{Cu}-\right.$ $\left.{ }^{\mathrm{II}}\left(\mu^{3}-\mathrm{OH}\right)\right]^{5+}$ (Figure 4 , left). The ca. $550 \mathrm{mV}$ separation of the redox couple indicates a substantial geometric difference at $\mathrm{Cu}^{\mathrm{II}} \mathrm{Cu}^{\mathrm{II}} \mathrm{Cu}^{\mathrm{II}}$ and $\mathrm{Cu}^{\mathrm{II}} \mathrm{Cu}^{\mathrm{I}} \mathrm{Cu}^{\mathrm{I}}$ states. As the tricopper center in $\mathbf{3}$ is exposed to bulk exterior, it can lose/gain interactions with solvents during redox processes, further raising the reorganization energy. Notably, further reduction of $\left[\mathrm{Cu}^{\mathrm{II}} \mathrm{Cu}^{\mathrm{I}} \mathrm{Cu}^{\mathrm{I}}\left(\mu_{3}-\right.\right.$ $\mathrm{OH})]^{3+}$ to $\left[\mathrm{Cu}^{\mathrm{I}} \mathrm{Cu}^{\mathrm{I}} \mathrm{Cu}^{\mathrm{I}}\left(\mu_{3}-\mathrm{OH}\right)\right]^{2+}$ was not observed within the voltage window of water. The $\mathrm{CV}$ of $\mathbf{3}$ becomes more reversi-
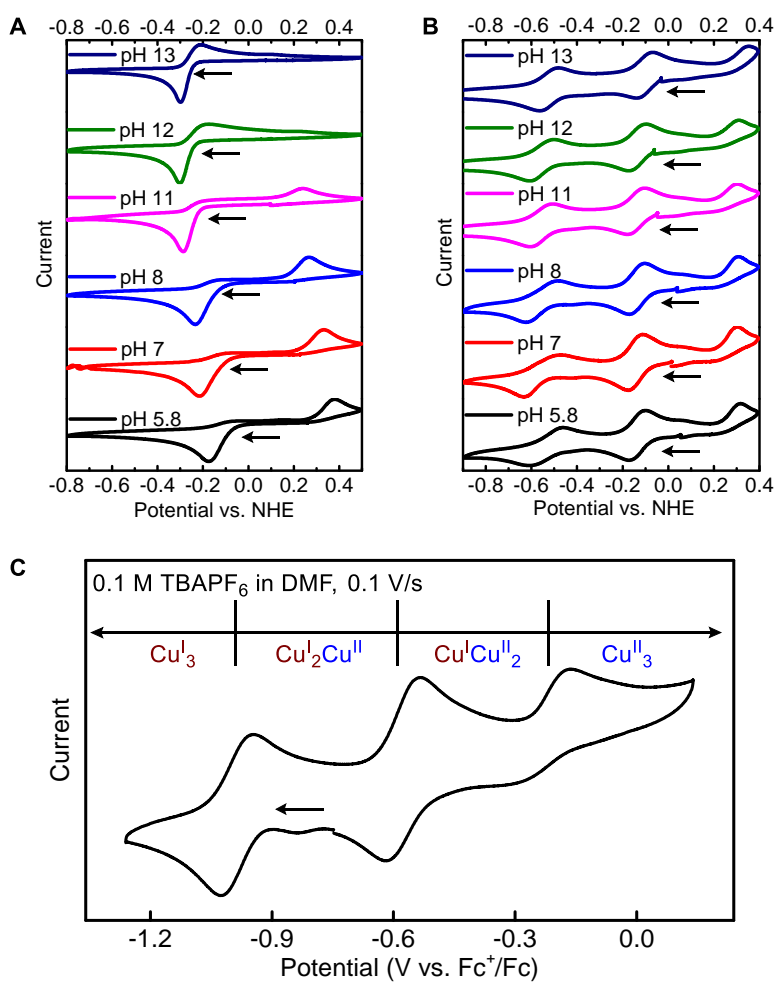

Figure 4. Cyclic voltammogram of (A) 3 and (C) 4, in aqueous environment with various $\mathrm{pH}$ from 5.8 to 13 (phosphate buffer solution). (C) CV of 4 in DMF with $0.1 \mathrm{M}\left({ }^{\mathrm{n}} \mathrm{Bu}_{4} \mathrm{~N}\right) \mathrm{PF} 6$. Scan rate of $0.1 \mathrm{~V} / \mathrm{s}$. Working electrode: glassy carbon; counter electrode: Pt wire; reference electrode: $\mathrm{Ag} / \mathrm{AgNO}_{3}$. ble as the $\mathrm{pH}$ increases from 5.6 to 13 , perhaps due to the deprotonation of central $\mu_{3}-\mathrm{OH}$ to $\mu_{3}-\mathrm{O}$, a stronger ligand that rigidifies the coordination environment (see supporting information).

In contrast to the irreversible redox behavior of $\mathbf{3}$, the cyclic voltammogram of 4 shows two reversible $\left(\mathrm{E}_{1 / 2}=-0.55 \mathrm{~V}\right.$ and $-0.13 \mathrm{~V}$ vs. NHE) and one irreversible $\left(\mathrm{E}_{\mathrm{ox}}=0.33 \mathrm{~V}\right.$ vs. NHE) redox events, allowing access to all four oxidation states of the tricopper cluster electrochemically (Figure 4B). The contrasting electrochemical behaviors of $\mathbf{3}$ and $\mathbf{4}$ suggest that the geometric constraints imposed by $\mathbf{T R E N}_{4}$ reduce the reorganization energies during ET. Additionally, the three redox events of complex 4 are insensitive to the $\mathrm{pH}$ of the buffer (Figure 4B), implicating that the protein-like cavitand of $\mathbf{T R E N}_{4}$ isolates the tricopper core from direct solvent interactions. The $\mathrm{CVs}$ of $\mathbf{4 b}$ in aqueous and non-aqueous environments, e.g. dimethylformamide or acetonitrile, are essentially the same (Figure 4C), further supporting that the redox of tricopper center in $\mathbf{4}$ is unaffected by the bulk exterior.

Synthesis and characterization of $4 \mathrm{a}\left(\mathrm{Cu}^{\mathrm{I}} \mathrm{Cu}^{\mathrm{I}} \mathrm{Cu}^{\mathrm{I}}\right)$ and $4 \mathrm{c}$ $\left(\mathbf{C u}^{\mathrm{II}} \mathbf{C u}^{\mathrm{II}} \mathbf{C u}^{\mathrm{I}}\right)$. The highly reversible oxidation and reduction couples of $\mathbf{4 b}$ prompted us to pursue the isolation of fully reduced [TREN $\left.{ }_{4} \mathrm{Cu}^{\mathrm{I}} \mathrm{Cu}^{\mathrm{I}} \mathrm{Cu}^{\mathrm{I}}\left(\mu_{3}-\mathrm{OH}\right)\right]^{2+}$ (4a) and two-hole $\left[\text { TREN }_{4} \mathrm{Cu}^{\mathrm{II}} \mathrm{Cu}^{\mathrm{II}} \mathrm{Cu}^{\mathrm{I}}\left(\mu_{3}-\mathrm{OH}\right)\right]^{4+}$ (4c, Figure 4A). Consistent with its electrochemical behavior, chemical oxidation of $\mathbf{4 b}$ with decamethylferrocenium hexafluorophosphate $\left(\mathrm{Me}_{10} \mathrm{FcPF}_{6}, \mathrm{E}_{1 / 2}=-0.49 \mathrm{~V}\right.$ vs. $\left.\mathrm{Fc}^{+} / \mathrm{Fc}\right)$ afforded a dark purple compound [TREN $\left.\mathrm{Cu}^{\mathrm{II}} \mathrm{Cu}^{\mathrm{II}} \mathrm{Cu}^{\mathrm{I}}\left(\mu_{3}-\mathrm{OH}\right)\right]\left(\mathrm{PF}_{6}\right)_{4}$ (4c) in $50 \%$ yield (Figure 5A). ${ }^{1} \mathrm{H}$ NMR spectrum of $\mathbf{4 c}$ show ca. 19 broad resonances from 0.13 to $122.5 \mathrm{ppm}$ (Figure S8), indicating an $\mathrm{S}=1$ ground state. Complex $\mathbf{4 c}$ is a rare example of a tricopper cluster with a $\mathrm{Cu}^{\mathrm{II}} \mathrm{Cu}^{\mathrm{II}} \mathrm{Cu}^{\mathrm{I}}$ oxidation state with the only other example being 2 reported by Murray et. al. ${ }^{19}$ Chemical reduction of $4 \mathbf{b}$ with cobaltocene $\left(\mathrm{Cp}_{2} \mathrm{Co}, \mathrm{E}_{1 / 2}=-1.3 \mathrm{~V}\right.$ vs. $\mathrm{Fc}^{+} / \mathrm{Fc}$ ) led to a rapid color change from blue to yellow (Figure $5 \mathrm{~B}$ ), and colorless crystals of fully reduced [TREN $\left.{ }_{4} \mathrm{Cu}^{\mathrm{I}} \mathrm{Cu}^{\mathrm{I}} \mathrm{Cu}^{\mathrm{I}}\left(\mu_{3}-\mathrm{OH}\right)\right]\left(\mathrm{PF}_{6}\right)_{2}$ (4a) were obtained by recrystallization. ${ }^{1} \mathrm{H}$ NMR characterization of $\mathbf{4 a}$ was hampered by its low solubility. Therefore, we synthesized an analog of
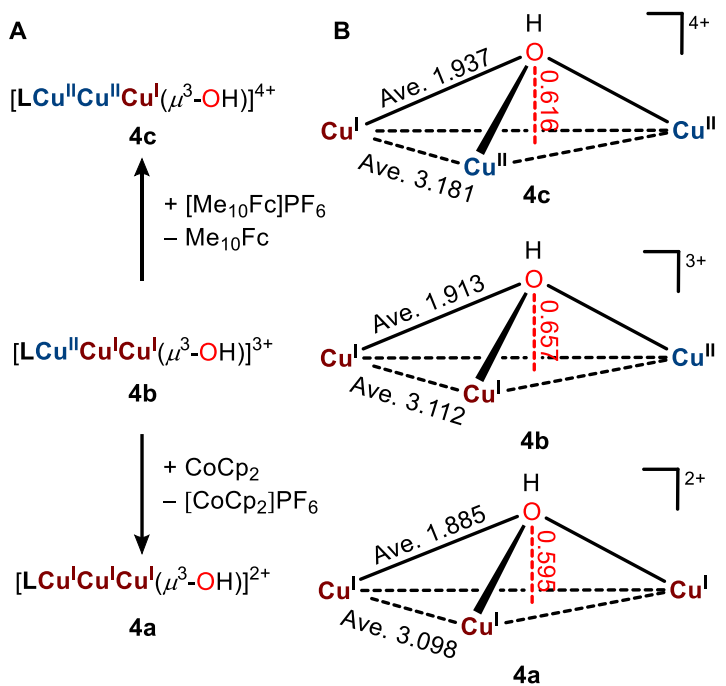

Figure 5. (A) Synthesis of $4 \mathbf{a}$ and $4 \mathbf{c}$ from $4 \mathbf{b}$. (B) Geometric comparison of the $\mathrm{Cu}_{3}\left[\mu_{3}-\mathrm{O}(\mathrm{H})\right]$ core in $\mathbf{4 a}, \mathbf{4} \mathbf{b}$, and $\mathbf{4 c}$. All bond metrics $(\AA)$ was determined based on X-ray singlecrystal diffraction. 
4a with 3,5-bis(trifluoromethyl)phenyl)borate $\left(\mathrm{BAr}_{4}{ }_{4}\right)$ counter anions $\left(\mathbf{4 a}-\mathrm{BAr}^{\mathrm{F}}{ }_{4}\right)$ by treating $\mathbf{4 b}-\mathrm{BAr}^{\mathrm{F}}{ }_{4}$ with $\mathrm{Cp}_{2} \mathrm{Co}$. All five ${ }^{1} \mathrm{H}$ NMR resonances of $\mathbf{4 a}-\mathrm{BAr}^{\mathrm{F}}{ }_{4}$ between 2 to $4.5 \mathrm{ppm}$ are quite broad, perhaps because of the dynamic behavior of $\mathrm{CH}_{2}$ groups on TREN $_{4}$ (Figure S6).

Both $\mathbf{4 a}$ and $\mathbf{4 c}$ were characterized by X-ray single crystallography (Figure, 5B, Figure S12-S13). The geometric features of $\mathrm{Cu}_{3}\left(\mu_{3}-\mathrm{OH}\right)$ are maintained throughout the redox processes. Complex $4 \mathbf{a}$ has a slightly contracted $\left[\mathrm{Cu}^{\mathrm{I}} \mathrm{Cu}^{\mathrm{I}} \mathrm{Cu}^{\mathrm{I}}\left(\mu_{3^{-}}\right.\right.$ $\mathrm{OH})]^{2+}$ core as evidenced by the shortened $\mathrm{Cu} \cdots \mathrm{Cu}$ distance (average $3.098 \AA$ in $\mathbf{4 a}$ comparing to $3.112 \AA$ in $\mathbf{4 b}$ ) and $\mathrm{Cu}-\mathrm{O}$ distances (average $1.885 \AA$ in $\mathbf{4 a}$ comparing to $1.913 \AA$ in $\mathbf{4 b}$ ). In contrast, the $\left[\mathrm{Cu}^{\mathrm{II}} \mathrm{Cu}^{\mathrm{II}} \mathrm{Cu}^{\mathrm{I}}\left(\mu_{3}-\mathrm{OH}\right)\right]^{4+}$ core in $\mathbf{4 c}$ expanded (average $\mathrm{Cu}$... Cu distance $3.181 \AA$, average $\mathrm{Cu}-\mathrm{O}$ distance $1.937 \AA$ ) because of the increased Coulombic repulsion. The minimal geometric differences of complex $\mathbf{4 a}, \mathbf{4 b}$, and $\mathbf{4 c}$ agree with their highly reversible redox behaviors. Importantly, the trigonal bipyramidal geometry of the $\mathrm{Cu}$ centers is preserved, even at the $\mathrm{Cu}^{\mathrm{I}} \mathrm{Cu}^{\mathrm{I}} \mathrm{Cu}^{\mathrm{I}}$ state, highlighting the extraordinary constraints imposed by the multicyclic ligand $\mathbf{T R E N}_{4}$, a feature not shared by $\mathbf{T R E N}_{3}$.
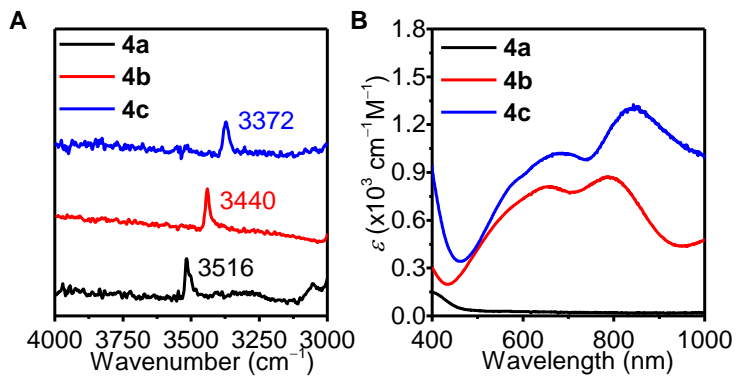

Figure 6. (A) Infrared and (B) UV-Vis spectra of $4 \mathbf{a}\left(\mathrm{Cu}^{\mathrm{I}-}\right.$ $\mathrm{Cu}^{\mathrm{I}} \mathrm{Cu}^{\mathrm{I}}$, black $), 4 \mathbf{b}\left(\mathrm{Cu}^{\mathrm{II}} \mathrm{Cu}^{\mathrm{I}} \mathrm{Cu}^{\mathrm{I}}\right.$, red $)$, and $4 \mathbf{c}\left(\mathrm{Cu}^{\mathrm{II}} \mathrm{Cu}^{\mathrm{II}} \mathrm{Cu}^{\mathrm{I}}\right.$, blue).

Infrared spectra of complexes $\mathbf{4 a}, \mathbf{4 b}, \mathbf{4 c}$ reveal that the $\mathrm{O}-\mathrm{H}$ stretches of $\mu_{3}-\mathrm{OH}$ progressively blueshifts from $3372 \mathrm{~cm}^{-1}$ $\left(\mathrm{Cu}^{\mathrm{II}} \mathrm{Cu}^{\mathrm{II}} \mathrm{Cu}^{\mathrm{I}}\right)$ to $3440 \mathrm{~cm}^{-1}\left(\mathrm{Cu}^{\mathrm{II}} \mathrm{Cu}^{\mathrm{I}} \mathrm{Cu}^{\mathrm{I}}\right)$ to $3516 \mathrm{~cm}^{-1}\left(\mathrm{Cu}^{\mathrm{I}} \mathrm{Cu}^{\mathrm{I}-}\right.$ $\left.\mathrm{Cu}^{\mathrm{I}}\right)$, indicating increasing $\mathrm{O}-\mathrm{H}$ bond strength as $\mathrm{Cu}$ oxidation state decreases (Figure 5A). The UV-vis spectra of $\mathbf{4 b}, \mathbf{4 c}$ both exhibit two broad intervalence charge-transfer bands (4b: 655 $\mathrm{nm}\left(800 \mathrm{M}^{-1} \mathrm{~cm}^{-1}\right)$ and $790 \mathrm{~nm}\left(870 \mathrm{M}^{-1} \mathrm{~cm}^{-1}\right), \mathbf{4 c}: 680 \mathrm{~nm}$ $\left(1000 \mathrm{M}^{-1} \mathrm{~cm}^{-1}\right)$ and $\left.850 \mathrm{~nm}\left(1300 \mathrm{M}^{-1} \mathrm{~cm}^{-1}\right)\right)$. Time-dependent density functional theory (TD-DFT) calculations at the BP86/TZVP level showed that these absorptions originate from charge transfers from combinations of copper $d$ orbitals to the LUMO, which features the $\sigma^{*}$ interaction of copper $d_{\mathrm{z} 2}$ and the $\mu_{3}-\mathrm{O} \mathrm{p}_{z}$ (Figure S22, Table S5-S6). Moreover, the calculated UV-vis spectra reflected the red-shifting trend from $\mathbf{4 b}$ to $\mathbf{4 c}$ (Figure S22).

Self-exchange rates $\left(k_{11}\right)$ and reorganization energies $(\lambda)$ of $4 a / 4 b$ and $4 b / 4 c$. The reorganization energies $(\lambda)$ of tricopper clusters during ET have important implications in oxygen reduction reaction catalyzed by $\mathrm{MCO}^{29}$ The reorganization energies of TNC have been used to rationalize the various rates of intermolecular ET between Type $1 \mathrm{Cu}$ sites and $\mathrm{TNC}^{21}$ as well as the inhibition ${ }^{30}$ or acceleration ${ }^{31}$ of ORR by halides. To further understand the kinetic factors that govern the redox of 4, we evaluated the self-exchange rates $\left(k_{11}\right)$ and reorganization energy $(\lambda)$ of $\mathrm{Cu}^{\mathrm{I}} \mathrm{Cu}^{\mathrm{I}} \mathrm{Cu}^{\mathrm{I}} / \mathrm{Cu}^{\mathrm{II}} \mathrm{Cu}^{\mathrm{I}} \mathrm{Cu}^{\mathrm{I}}$ and $\mathrm{Cu}^{\mathrm{II}} \mathrm{Cu}^{\mathrm{I}} \mathrm{Cu}^{\mathrm{I}}$ $/ \mathrm{Cu}^{\mathrm{II}} \mathrm{Cu}^{\mathrm{II}} \mathrm{Cu}^{\mathrm{I}}$ redox couples. Determine of $k_{11}$ using ${ }^{1} \mathrm{H}$ NMR line broadening experiment ${ }^{32}$ was not feasible due to the dynamic behavior of $\mathrm{CH}_{2}$ resonances in $\mathbf{4 a}$ and paramagnetic nature of 4c. As an alternative, we employed an electrochemical method reported by Nicholson; ${ }^{33,34}$ the self-exchange rates of $\mathbf{4 a} / \mathbf{4 b}$ and $\mathbf{4 b} / \mathbf{4} \mathbf{c}$ were determined to be $7.4(2) \times 10^{5} \mathrm{M}^{-1} \mathrm{~s}^{-1}$ and $7.2(2) \times 10^{5} \mathrm{M}^{-1} \mathrm{~s}^{-1}$, respectively (see supporting information). These fast ET rates approach the fastest synthetic mono- and dicopper system $\left(10^{5}-10^{6} \mathrm{M}^{-1} \mathrm{~s}^{-1}\right)^{33,35-39}$ as well as Nature's blue copper ET protein $10^{5}-10^{6} \mathrm{M}^{-1} \mathrm{~s}^{-1}$. ${ }^{40,41}$ The corresponding reorganization energies for $\mathbf{4 a} / \mathbf{4 b}$ and $\mathbf{4 b} / \mathbf{4} c$ were calculated to be 1.21(1) eV and 1.21(1) eV using equation 1 (Z $\left.=10^{11} \mathrm{M}^{-1} \mathrm{~s}^{-1}, \mathrm{~T}=298 \mathrm{~K}\right){ }^{39,42}$

$k_{11}=\mathrm{Z} \exp \left(\frac{-\lambda}{4 R T}\right)$

The reorganization energy $(\lambda)$ can be further partitioned into inner-sphere reorganization energy $\left(\lambda_{i}\right)$ and outersphere reorganization energy $\left(\lambda_{o}\right)$, which are associated with structural changes of the first coordination sphere and surrounding solvents, respectively (eq 2). The outersphere reorganization energy was calculated to be $0.93 \mathrm{eV}$ for $\mathbf{4 a} / \mathbf{4 b}$ and $0.93 \mathrm{eV}$ for $\mathbf{4 b} / \mathbf{4} \mathbf{c}$ using eq 3 , where $\Delta e$ is the elementary charge, $a_{l}$ and $a_{2}$ are the radii of redox partners, and $D_{\text {opt }}$ and $D_{\text {stat }}$ are the optical- and static-dielectric constants of acetonitrile ${ }^{43}$ at $298.15 \mathrm{~K}$. Thus, the inner-sphere reorganization energy for $\mathbf{4 a} / \mathbf{4 b}$ and $\mathbf{4 b} / \mathbf{4 c}$ are estimated to be $0.28 \mathrm{eV}$ and $0.28 \mathrm{eV}$ using equation 2.

$\lambda=\lambda_{i}+\lambda_{o}$

$\lambda_{o}=\Delta e^{2}\left[\frac{1}{2 a_{1}}+\frac{1}{2 a_{2}}-\frac{1}{a_{1}+a_{2}}\right]\left[\frac{1}{D_{\text {opt }}}-\frac{1}{D_{\text {stat }}}\right]$

$\lambda_{i}=\lambda_{\text {ox }}+\lambda_{\text {red }}$

Determination of $k_{l l}$ of $\mathbf{3}$ was not viable, since the $\mathrm{Cu}^{\mathrm{II}} \mathrm{Cu}^{\mathrm{II}}$ $\mathrm{Cu}^{\mathrm{II}} / \mathrm{Cu}^{\mathrm{II}} \mathrm{Cu}^{\mathrm{I}} \mathrm{Cu}^{\mathrm{I}}$ was not reversible, and $\mathrm{Cu}^{\mathrm{II}} \mathrm{Cu}^{\mathrm{I}} \mathrm{Cu}^{\mathrm{I}} / \mathrm{Cu}^{\mathrm{I}} \mathrm{Cu}^{\mathrm{I}} \mathrm{Cu}^{\mathrm{I}}$ was not observed experimentally. Therefore, we turn to computational study to compare the reorganization energy of $\mathbf{3}$ and 4. The inner-sphere reorganization energy $\lambda_{i}$ can be calculated by eq 4 , where $\lambda_{o x}$ and $\lambda_{\text {red }}$ are the reorganization energy of the reduced and oxidized complexes. $\lambda_{o x}$ and $\lambda_{\text {red }}$ can be computationally estimated by the energy required to distort the equilibrium geometries to their redox-partners' geometries (Figure S21). ${ }^{29,30,44}$ For example, $\lambda_{o x}$ of $\mathbf{4 a} / \mathbf{4 b}$ couple is the energy of $\mathbf{4 b}$ calculated at $\mathbf{4 a}$ 's optimal geometry minus the energy of $\mathbf{4 b}$ at its optimal geometry. Similarly, the $\lambda_{\text {red }}$ of $\mathbf{4 a} \mathbf{a} / \mathbf{4 b}$ couple is the energy of $\mathbf{4 a}$ calculated at $\mathbf{4 b}$ 's optimal geometry minus the energy of $\mathbf{4 a}$ at its optimal geometry (Scheme 1). The optimized geometries of $\mathbf{3}$ and $\mathbf{4}$ at all four redox states were obtained at BP86/TZVP $(\mathrm{Cu}) / \mathrm{SVP}(\mathrm{H}, \mathrm{C}, \mathrm{N}, \mathrm{O})$ level using their crystallographic structures as starting points. The reorganization energies of $\mathbf{3}$ and $\mathbf{4}$ during three ET processes $\left(\mathrm{Cu}^{\mathrm{II}} \mathrm{Cu}^{\mathrm{II}-}\right.$ $\mathrm{Cu}^{\mathrm{II}} / \mathrm{Cu}^{\mathrm{II}} \mathrm{Cu}^{\mathrm{II}} \mathrm{Cu}^{\mathrm{I}}, \quad \mathrm{Cu}^{\mathrm{II}} \mathrm{Cu}^{\mathrm{II}} \mathrm{Cu}^{\mathrm{I}} / \mathrm{Cu}^{\mathrm{II}} \mathrm{Cu}^{\mathrm{I}} \mathrm{Cu}^{\mathrm{I}}, \quad \mathrm{Cu}^{\mathrm{II}} \mathrm{Cu}^{\mathrm{I}}$ $\left.\mathrm{Cu}^{\mathrm{I}} / \mathrm{Cu}^{\mathrm{I}} \mathrm{Cu}^{\mathrm{I}} \mathrm{Cu}^{\mathrm{I}}\right)$ were summarized in Scheme 1. There are several competing spin states for the $\mathrm{Cu}^{\mathrm{II}} \mathrm{Cu}^{\mathrm{II}} \mathrm{Cu}^{\mathrm{II}}$ oxidation state. Since our goal is to compare the reorganization energies of $\mathbf{3}$ 
A $\left[\text { TREN }_{4} \mathrm{Cu}^{\prime} \mathrm{Cu}^{\prime} \mathrm{Cu}{ }^{\prime} \mathrm{OH}\right]^{*}$

[TREN $\left.{ }_{4} \mathrm{Cu}^{\prime \prime} \mathrm{Cu}{ }^{\prime} \mathrm{Cu}{ }^{\prime} \mathrm{OH}\right]^{*}$

[TREN $\left.\mathrm{Cu}^{\prime \prime} \mathrm{Cu}^{\prime \prime} \mathrm{Cu}{ }^{\prime} \mathrm{OH}\right]^{*}$

[TREN $\left.4 \mathrm{Cu}^{\prime \prime} \mathrm{Cu}{ }^{\prime \prime} \mathrm{Cu}{ }^{\prime \prime} \mathrm{OH}\right]^{*}$
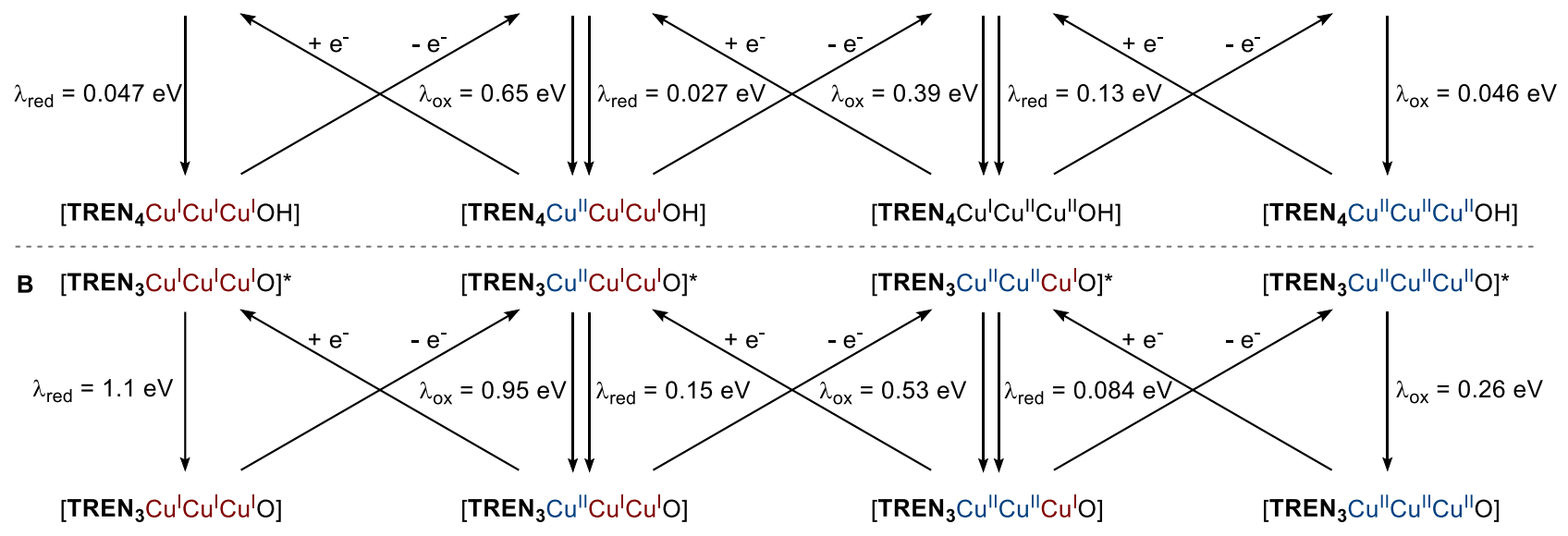

Scheme 1. Computed inner-sphere reorganization energy of (A) 4 and (B) 3 .

and 4, we have only studied the electronic state with the lowest energies, which are the quartet states with three ferromagnetically coupled $\mathrm{Cu}$ (II) centers (Table S3). Complexes at $\mathrm{Cu}^{\mathrm{II}} \mathrm{Cu}^{\mathrm{II}} \mathrm{Cu}^{\mathrm{I}}$ oxidation state were treated as triplet according to the spin state of $\mathbf{4 c}$.

The inner-sphere reorganization energies $\left(\lambda_{i}\right)$ of $\mathbf{4 a / 4 b}$ and $\mathbf{4 b} / \mathbf{4 c}$ were well reproduced by calculations, giving confidence in the calculated $\lambda_{i}$ in Table 1 . The $\lambda_{i}$ values for $\mathbf{3}$ and $\mathbf{4}$ differ the most for $\mathrm{Cu}^{\mathrm{II}} \mathrm{Cu}^{\mathrm{I}} \mathrm{Cu}^{\mathrm{I}} / \mathrm{Cu}^{\mathrm{I}} \mathrm{Cu}^{\mathrm{I}} \mathrm{Cu}^{\mathrm{I}}$ redox couple $(2.1 \mathrm{eV}$ for 3 vs. $0.70 \mathrm{eV}$ for 4 ), consistent with the fact that the reduction of 3 to $\mathrm{Cu}^{\mathrm{I}} \mathrm{Cu}^{\mathrm{I}} \mathrm{Cu}^{\mathrm{I}}$ state is not observed. The large inner-sphere reorganization energy for $\left[\mathbf{T R E N}_{3} \mathrm{Cu}^{\mathrm{II}} \mathrm{Cu}^{\mathrm{I}} \mathrm{Cu}^{\mathrm{I}}\left(\mu_{3}\right.\right.$ $\mathrm{O})]^{2+} /\left[\mathrm{TREN}_{3} \mathrm{Cu}^{\mathrm{I}} \mathrm{Cu}^{\mathrm{I}} \mathrm{Cu}^{\mathrm{I}}\left(\mu_{3}-\mathrm{O}\right)\right]^{+}(2.1 \mathrm{eV})$ may be rationalized by its trigonal bipyramidal $\mathrm{Cu}$ centers, a geometry highly preferred by $\mathrm{Cu}(\mathrm{II})$. As a result, the reduction of $\mathrm{Cu}^{\mathrm{II}} \mathrm{Cu}^{\mathrm{I}} \mathrm{Cu}^{\mathrm{I}}$ to $\mathrm{Cu}^{\mathrm{I}} \mathrm{Cu}^{\mathrm{I}} \mathrm{Cu}^{\mathrm{I}}$, in an unconstrained environment, could be coupled with chemical reactions, e.g. ligand dissociation/reorganization. In contrast, multicyclic ligand TREN 4 prevents such ligand dissociation and restrict solvent access to the tricopper centers, synergistically yielding small reorganization energy and fast ET rates.

Table 1. Inner-sphere reorganization energy $\left(\lambda_{i}, e V\right)$ of $\mathbf{4}$ and $\mathbf{3}$.

\begin{tabular}{|c|c|c|c|}
\hline & $\begin{array}{c}\mathrm{Cu}^{\mathrm{II}} \mathrm{Cu}^{\mathrm{I}} \mathrm{Cu}^{\mathrm{I}} / \\
\mathrm{Cu}^{\mathrm{I}} \mathrm{Cu}^{\mathrm{I}} \mathrm{Cu}^{\mathrm{I}}\end{array}$ & $\begin{array}{c}\mathrm{Cu}^{\mathrm{II}} \mathrm{Cu}^{\mathrm{II}} \mathrm{Cu}^{\mathrm{I}} / \\
\mathrm{Cu}^{\mathrm{II}} \mathrm{Cu}^{\mathrm{I}} \mathrm{Cu}^{\mathrm{I}}\end{array}$ & $\begin{array}{r}\mathrm{Cu}^{\mathrm{II}} \mathrm{Cu}^{\mathrm{II}} \mathrm{Cu}^{\mathrm{II}} / \\
\mathrm{Cu}^{\mathrm{II}} \mathrm{Cu}^{\mathrm{II}} \mathrm{Cu}^{\mathrm{I}}\end{array}$ \\
\hline \multirow[t]{2}{*}{4} & $0.28^{\mathrm{a}}$ & $0.28^{a}$ & $0.18^{b}$ \\
\hline & $0.70^{\mathrm{b}}$ & $0.42^{\mathrm{b}}$ & \\
\hline 3 & $2.1^{\mathrm{b}}$ & $0.68^{b}$ & $0.34^{b}$ \\
\hline
\end{tabular}

${ }^{a}$ Experimental reorganization energies determined by electrochemical measurements ${ }^{b}$ Calculated reorganization energies by DFT.

Oxygen reduction reactivity of $4 a$. The generation of the fully reduced $\mathrm{Cu}^{\mathrm{I}} \mathrm{Cu}^{\mathrm{I}} \mathrm{Cu}^{\mathrm{I}}$ state is crucial for oxygen reduction reaction at MCO. Encouraged by the redox capability of 4, we studied its ability to reduce $\mathrm{O}_{2}$. As followed by UV-Vis spectroscopy (Figure S10), fully reduced 4a slowly reduced $\mathrm{O}_{2}$, while $\mathbf{4 b}$ and $\mathbf{4 c}$ did not react with $\mathrm{O}_{2}$, consistent with the fact that generation of $\mathrm{Cu}^{\mathrm{I}} \mathrm{Cu}^{\mathrm{I}} \mathrm{Cu}^{\mathrm{I}}$ state is required to harness the oxidative power of $\mathrm{O}_{2}$. Addition of proton sources, e.g. acetic acid, significantly accelerated the rate of ORR. Complex $\mathbf{4 b}$ was regenerated in $96(2) \%$ spectroscopic yield. The product of the $\mathrm{O}_{2}$ reduction was assigned as $\mathrm{H}_{2} \mathrm{O}_{2}$ in 97(2)\% yield based on iodometric titration (see supporting information). ${ }^{45}$ To elucidate the mechanism of ORR, we performed the reaction $4 \mathbf{4}$ with ${ }^{18} \mathrm{O}_{2}$ in the presence of acetic acid. The resulting solution of $\mathbf{4 b}$ was analyzed by ESI-MS for ${ }^{18} \mathrm{O}$ incorporation. Spectrum simulations show $10 \%$ of ${ }^{18} \mathrm{O}$ incorporation, indicating that the ORR mostly likely proceeds through an outer-sphere mechanism, ${ }^{46}$ consistent with the predominant $\mathrm{H}_{2} \mathrm{O}_{2}$ selectivity.

\section{SUMMARY AND CONCLUSIONS}

In conclusion, we report that the encapsulation of tricopper core in a protein-like cavitand activates allows the redox of three $\mathrm{Cu}^{\mathrm{II}} / \mathrm{Cu}^{\mathrm{I}}$ to be harnessed effectively in a homogeneous synthetic system. The tricopper complex was isolated and characterized in three of four oxidation states, showing that the redox-induced geometric changes were minimal. The encapsulated tricopper complex has self-exchange ET rates of $10^{5}-$ $10^{6} \mathrm{M}^{-1} \mathrm{~s}^{-1}$, approaching Nature's copper electron transfer sites (blue copper protein $10^{5}-10^{6} \mathrm{M}^{-1} \mathrm{~s}^{-1}$ ). Marcus analysis indicates that the reorganization energy required for the reduction of $\mathbf{4 b}$ to $\mathbf{4 a}$ was $0.70 \mathrm{eV}$, much smaller than that for solvent-exposed $3(2.1 \mathrm{eV})$. These results are particularly consistent with the minimal structural difference of 4 at $\mathrm{Cu}^{\mathrm{I}} \mathrm{Cu}^{\mathrm{I}} \mathrm{Cu}^{\mathrm{I}}, \mathrm{Cu}^{\mathrm{II}} \mathrm{Cu}^{\mathrm{I}} \mathrm{Cu}^{\mathrm{I}}$, and $\mathrm{Cu}^{\mathrm{II}} \mathrm{Cu}^{\mathrm{II}} \mathrm{Cu}^{\mathrm{I}}$ state and suggest that multicyclic cryptands TREN $_{4}$ is effective at mimicking a protein-like environment. The geometric constraints and exclusion of solvent interactions synergistically reduce the reorganization energy of electron transfer. At last, we show that the fully reduced $\mathrm{Cu}^{\mathrm{I}} \mathrm{Cu}^{\mathrm{I}-}$ $\mathrm{Cu}^{\mathrm{I}}$ state can participate in oxygen reduction reaction, mimicking Nature's multicopper oxidases. Taken together, our work provides insights into Nature strategy in leveraging the cooperativity of multimetallic sties in multielectron transformation - redox processes that are not operational in bulk solution could potentially be accomplished by full encapsulation of the active site in an isolated environment. 


\section{ASSOCIATED CONTENT}

The Supporting information is available free of charge on the ACS Publications website at DOI:.

Experimental details, including characterization data, spectra, and computational procedures.

Crystallographic data for 4a (CIF: 1984893)

Crystallographic data for 4b (CIF: 1984894)

Crystallographic data for 4c (CIF: 1984895)

Crystallographic data for $\mathbf{4 a}-\mathrm{BAr}_{4}{ }_{4}$ (CIF: 1987932)

\section{AUTHOR INFORMATION}

\section{Corresponding Author}

*zhang.8941@osu.edu

\section{Notes}

The authors declare no competing financial interest.

\section{ACKNOWLEDGMENT}

This material is based on work supported by the U.S. National Science Foundation under award no. CHE-1904560 (S.Z.) and ACS-PRF (59036-DNI3). The authors thank The Ohio State University Department Chemistry and Biochemistry for additional financial support. High-performance computing resources were provided by the Ohio Supercomputer Center.

\section{REFERENCES}

(1) Gupta, A. K.; Tolman, W. B. $\mathrm{Cu}(\mathrm{I}) / \mathrm{O}_{2}$ Chemistry Using a $\beta$ Diketiminate Supporting Ligand Derived from N,NDimethylhydrazine: A $\left[\mathrm{Cu}_{3} \mathrm{O}_{2}\right]^{3+}$ Complex with Novel Reactivity. Inorg. Chem. 2012, 51, 1881.

(2) Cole, A. P.; Root, D. E.; Mukherjee, P.; Solomon, E. I.; Stack, T. D. P. A Trinuclear Intermediate in the Copper-Mediated Reduction of $\mathrm{O}_{2}$ : Four Electrons from Three Coppers. Science 1996, $273,1848$.

(3) Taki, M.; Teramae, S.; Nagatomo, S.; Tachi, Y.; Kitagawa, T.; Itoh, S.; Fukuzumi, S. Fine-Tuning of Copper(I)-Dioxygen Reactivity by 2-(2-Pyridyl)Ethylamine Bidentate Ligands. $J$. Am. Chem. Soc. 2002, 124, 6367.

(4) Cook, B. J.; Di Francesco, G. N.; Kieber-Emmons, M. T.; Murray, L. J. A Tricopper(I) Complex Competent for O Atom Transfer, C-H Bond Activation, and Multiple $\mathrm{O}_{2}$ Activation Steps. Inorg. Chem. 2018, 57, 11361.

(5) Lionetti, D.; Day, M. W.; Agapie, T. Metal-Templated Ligand Architectures for Trinuclear Chemistry: Tricopper Complexes and Their $\mathrm{O}_{2}$ Reactivity. Chem. Sci. 2013, 4, 785.

(6) Engelmann, X.; Farquhar, E. R.; England, J.; Ray, K. FourElectron Reduction of Dioxygen to Water by a Trinuclear Copper Complex. Inorganica Chim. Acta 2018, 481, 159.

(7) Tsui, E. Y.; Day, M. W.; Agapie, T. Trinucleating Copper: Synthesis and Magnetostructural Characterization of Complexes Supported by a Hexapyridyl 1,3,5-Triarylbenzene Ligand. Angew. Chemie - Int. Ed. 2011, 50, 1668.

(8) Karlin, K. D.; Qingfen, G.; Farooq, A.; Shuncheng, L.; Zubieta, J. Synthesis and X-Ray Crystal Structure of a Trinuclear Copper(I) Cluster. Inorganica Chim. Acta 1989, 165, 37.

(9) Brown, E. C.; Johnson, B.; Palavicini, S.; Kucera, B. E.; Casella, L.; Tolman, W. B. Modular Syntheses of Multidentate Ligands with Variable N-Donors: Applications to Tri- and Tetracopper(I) Complexes. Dalt. Trans. 2007, No. 28, 3035.

(10) Solomon, E. I.; Sundaram, U. M.; Machonkin, T. E. Multicopper Oxidases and Oxygenases. Chem. Rev. 2002, 96, 2563.
Mano, N.; Kim, H.-H.; Heller, A. On the Relationship between the Characteristics of Bilirubin Oxidases and $\mathrm{O}_{2}$ Cathodes Based on Their "Wiring." J. Phys. Chem. B 2002, 106, 8842.

(12) Wang, V. C.-C.; Maji, S.; Chen, P. P.-Y.; Lee, H. K.; Yu, S. S.F.; Chan, S. I. Alkane Oxidation: Methane Monooxygenases, Related Enzymes, and Their Biomimetics. Chem. Rev. 2017, 117, 8574.

(13) Chen, P. P.-Y.; Yang, R. B.-G.; Lee, J. C.-M.; Chan, S. I. Facile O-Atom Insertion into $\mathrm{C}-\mathrm{C}$ and $\mathrm{C}-\mathrm{H}$ Bonds by a Trinuclear Copper Complex Designed to Harness a Singlet Oxene. Proc. Natl. Acad. Sci. U. S. A. 2007, 104, 14570.

(14) Chan, S. I.; Lu, Y.-J.; Nagababu, P.; Maji, S.; Hung, M.-C.; Lee, M. M.; Hsu, I.-J.; Minh, P. D.; Lai, J. C.-H.; Ng, K. Y.; et al. Efficient Oxidation of Methane to Methanol by Dioxygen Mediated by Tricopper Clusters. Angew. Chemie Int. Ed. 2013 52,3731 .

Yoon, J.; Solomon, E. I. Electronic Structures of Exchange Coupled Trigonal Trimeric Cu(II) Complexes : Spin Frustration, Antisymmetric Exchange, Pseudo-A Terms, and Their Relation to $\mathrm{O}_{2}$ Activation in the Multicopper Oxidases. Coord. Chem. Rev. 2007, 251, 379.

(16) Salvadeo, E.; Dubois, L.; Latour, J. Trinuclear Copper Complexes as Biological Mimics: Ligand Designs and Reactivities. Coord. Chem. Rev. 2018, 374, 345.

(17) Marcus, R. A. On the Theory of Oxidation-reduction Reactions Involving Electron Transfer. I. J. Chem. Phys. 1956, 24, 966.

(18) Rivera-carrillo, M.; Chakraborty, I.; Mezei, G.; Webster, R. D.; Raptis, R. G. Tuning of the $\left[\mathrm{Cu}_{3}(\mu-\mathrm{O})\right]^{4+} /^{5+}$ Redox Couple : Spectroscopic Evidence of Charge Delocalization in the MixedValent $\left[\mathrm{Cu}_{3}(\mu-\mathrm{O})\right]^{5+}$ Species. Inorg. Chem. 2008, 47, 7644.

(19) Cook, B. J.; Francesco, G. N. Di; Ferreira, R. B.; Lukens, J. T.; Silberstein, K. E.; Keegan, B. C.; Catalano, V. J.; Lancaster, K. M.; Shearer, J.; Murray, L. J. Chalcogen Impact on Covalency within Molecular $\left[\mathrm{Cu}_{3}\left(\mu_{3}-\mathrm{E}\right)\right]^{3+}$ Clusters $(\mathrm{E}=\mathrm{O}, \mathrm{S}, \mathrm{Se})$ : A Synthetic, Spectroscopic, and Computational Study. Inorg. Chem. 2018, 57, 11382.

(20) Jones, S. M.; Solomon, E. I. Electron Transfer and Reaction Mechanism of Laccases. Cell. Mol. Life Sci. 2015, 72, 869.

(21) Heppner, D. E.; Kjaergaard, C. H.; Solomon, E. I. Molecular Origin of Rapid versus Slow Intramolecular Electron Transfer in the Catalytic Cycle of the Multicopper Oxidases. J. Am. Chem. Soc. 2013, 135, 12212.

(22) Suh, M. P.; Han, M. Y.; Lee, J. H.; Min, K. S.; Hyeon, C. OnePot Template Synthesis and Properties of a Molecular Bowl: Dodecaaza Macrotetracycle with $\mu_{3}$-Oxo and $\mu_{3}$-Hydroxo Tricopper ( II ) Cores. J. Am. Chem. Soc. 1998, 120, 3819.

(23) Yoon, J.; Mirica, L. M.; Stack, T. D. P.; Solomon, E. I. Variable-Temperature, Variable-Field Magnetic Circular Dichroism Studies of Tris-Hydroxy- and $\mu_{3}$-Oxo-Bridged Trinuclear $\mathrm{Cu}$ (II) Complexes: Evaluation of Proposed Structures of the Native Intermediate of the Multicopper Oxidases. J. Am. Chem. Soc. 2005, 127, 13680.

(24) Yoon, J.; Solomon, E. I. Ground-State Electronic and Magnetic Properties of a $\mu_{3}$-Oxo-Bridged Trinuclear $\mathrm{Cu}(\mathrm{II})$ Complex: Correlation to the Native Intermediate of the Multicopper Oxidases. Inorg. Chem. 2005, 44, 8076.

(25) Bing-guang, Z.; Hong, M.; Chun-ying, D.; Cheng, H.; Qing-jin, M.; Zhe-ming, W.; Chun-hua, Y. Novel Highly Symmetrical Cube-Shaped Cation with 16-Nitrogen Donors. Chem. Commun. 2001, 24, 2652.

(26) Garribba, E.; Micera, G. The Determination of the Geometry of $\mathrm{Cu}$ (II) Complexes An EPR Spectroscopy Experiment. J. Chem. Educ. 2006, 83, 1229.

(27) Kjaergaard, C. H.; Jones, S. M.; Mano, N.; Solomon, E. I. TwoElectron Reduction versus One-Electron Oxidation of the Type 3 Pair in the Multicopper Oxidases. J. Am. Chem. Soc. 2015, $137,8783$.

(28) Kjaergaard, C. H.; Durand, F.; Tasca, F.; Qayyum, M. F.; Kauffmann, B.; Gounel, S.; Suraniti, E.; Hodgson, K. O.; Hedman, B.; Mano, N.; et al. Spectroscopic and Crystallographic Characterization of "Alternative Resting" and 
"Resting Oxidized" Enzyme Forms of Bilirubin Oxidase: Implications for Activity and Electrochemical Behavior of Multicopper Oxidases. J. Am. Chem. Soc. 2012, 134, 5548.

(29) Hu, L.; Farrokhnia, M.; Heimdal, J.; Shleev, S.; Rulíšek, L.; Ryde, U. Reorganization Energy for Internal Electron Transfer in Multicopper Oxidases. J. Phys. Chem. B 2011, 115, 13111.

(30) Kepp, K. P. Halide Binding and Inhibition of Laccase Copper Clusters: The Role of Reorganization Energy. Inorg. Chem. 2015, 54, 476.

(31) Tian, S.; Jones, S. M.; Jose, A.; Solomon, E. I. Chloride Control of the Mechanism of Human Serum Ceruloplasmin (Cp) Catalysis. J. Am. Chem. Soc. 2019, 141, 10736.

(32) Dahl, E. W.; Szymczak, N. K. Hydrogen Bonds Dictate the Coordination Geometry of Copper: Characterization of a Square-Planar Copper (I) Complex. Angew. Chemie 2016, 128, 3153.

(33) Gennari, M.; Pécaut, J.; DeBeer, S.; Neese, F.; Collomb, M.-N.; Duboc, C. A Fully Delocalized Mixed-Valence Bis- $\mu$ (Thiolato) Dicopper Complex: A Structural and Functional Model of the Biological CuA Center. Angew. Chemie Int. Ed. 2011, 50, 5662.

(34) Nicholson, R. S. Theory and Application of Cyclic Voltammetry for Measurement of Electrode Reaction Kinetics. Anal. Chem. 1965, 37, 1351.

(35) Dahl, E. W.; Szymczak, N. K. Hydrogen Bonds Dictate the Coordination Geometry of Copper: Characterization of a Square-Planar Copper(I) Complex. Angew. Chemie Int. Ed. 2016, $128,3153$.

(36) Doine, H.; Yano, Y.; Swaddle, T. W. Kinetics of the Bis(2,9Dimethyl-1,10-Phenanthroline)Copper(I/II) Self Exchange Reaction in Solution. Inorg. Chem. 1989, 28, 2319.

(37) Krylova, K.; Kulatilleke, C. P.; Heeg, M. J.; Salhi, C. A.; Ochrymowycz, L. A.; Rorabacher, D. B. A Structural Strategy for Generating Rapid Electron-Transfer Kinetics in Copper(II/I) Systems. Inorg. Chem. 1999, 38, 4322.

(38) Pulliam, E. J.; McMillin, D. R. Self-Exchange Rate for the Copper(II)/Copper(I) Couple Complexed to TAAB, an $\mathrm{N}_{4}$ Macrocycle. Inorg. Chem. 1984, 23, 1172.

(39) Zerk, T. J.; Saouma, C. T.; Mayer, J. M.; Tolman, W. B. Low Reorganization Energy for Electron Self-Exchange by a Formally Copper(III,II) Redox Couple. Inorg. Chem. 2019, 58, 14151.

(40) Slutter, C. E.; Langen, R.; Sanders, D.; Lawrence, S. M.; Wittung, P.; Di Bilio, A. J.; Hill, M. G.; Fee, J. A.; Richards, J. H.; Winkler, J. R.; et al. Electron-Transfer Studies with the CuA Domain of Thermus Thermophilus Cytochrome Ba3. Inorganica Chim. Acta 1996, 243, 141.

(41) Adman, E. T.; Canters, G. W.; Hill, H. A. O.; Kitchen, N. A The Redox Properties of Azurin from Pseudomonas Aeruginosa as Studied by High Frequency Proton NMR. Inorganica Chim. Acta 1983, 79, 127.

(42) Eberson, L. E. Electron Transfer Reactions in Organic Chemistry; Springer-Verlag: Berlin, 1987.

(43) Moreau, C.; Gérard, D. Thermodynamic and Physical Behaviour of Water + Acetonitrile Mixtures. Dielectric Properties. J. Chem. Thermodyn. 1976, 8, 403.

(44) Sigfridsson, E.; Olsson, M. H. M.; Ryde, U. Inner-Sphere Reorganization Energy of Iron-Sulfur Clusters Studied with Theoretical Methods. Inorg. Chem. 2001, 40, 2509.

(45) Garcia-bosch, I.; Cowley, R. E.; Díaz, D. E.; Siegler, M. A.; Nam, W.; Solomon, E. I.; Karlin, K. D. Dioxygen Activation by a Macrocyclic Copper Complex Leads to a $\mathrm{Cu}_{2} \mathrm{O}_{2}$ Core with Unexpected Structure and Reactivity. Chem. - A Eur. J. 2016, 22, 5133.

(46) Pegis, M. L.; Wise, C. F.; Martin, D. J.; Mayer, J. M. Oxygen Reduction by Homogeneous Molecular Catalysts and Electrocatalysts. Chem. Rev. 2018, 118, 2340. 

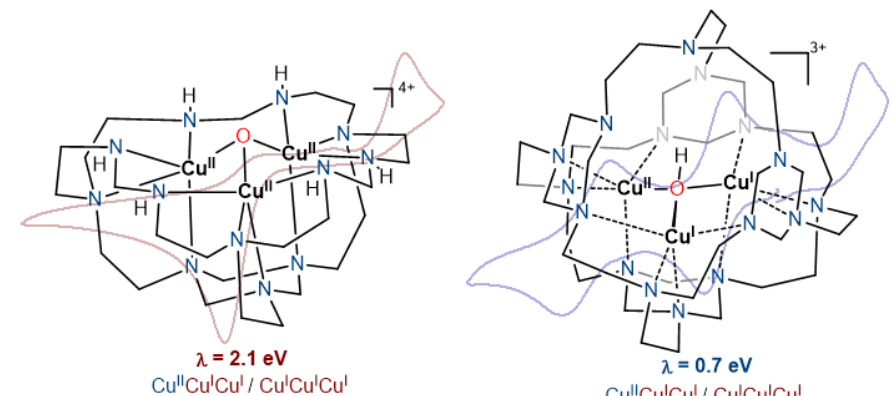

$\mathrm{Cu}^{\prime \prime} \mathrm{Cu}^{\prime} \mathrm{Cu}^{\prime} / \mathrm{Cu}^{\prime} \mathrm{Cu}^{\prime} \mathrm{Cu}$ 


\title{
Encapsulation of synthetic tricopper cluster in a pro- tein-like cavitand enables facile redox processes from $\mathrm{Cu}^{\mathrm{I}} \mathrm{Cu}^{\mathrm{I}} \mathrm{Cu}^{\mathrm{I}}$ to $\mathrm{Cu}^{\mathrm{II}} \mathrm{Cu}^{\mathrm{II}} \mathrm{Cu}^{\mathrm{II}}$ states
}

\author{
Weiyao Zhang, Curtis E. Moore, Shiyu Zhang*
}

Department of Chemistry and Biochemistry, The Ohio State University, 100 West 18th Avenue, Columbus, Ohio 43210, United States

\section{Contents}

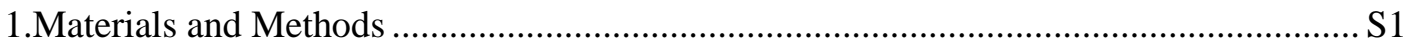

Synthesis and characterization of $\left[\mathbf{T R E N}_{4} \mathrm{Cu}^{\mathrm{I}} \mathrm{Cu}^{\mathrm{I}} \mathrm{Cu}^{\mathrm{II}}\left(\mu_{3}-\mathrm{OH}\right)\right]\left(\mathrm{PF}_{6}\right)_{3}(\mathbf{4 b}) \ldots \ldots \ldots \ldots \ldots \ldots . . . . . . . . . .22$

Synthesis and characterization of $\left[\mathbf{T R E N}_{4} \mathrm{Cu}^{\mathrm{I}} \mathrm{Cu}^{\mathrm{I}} \mathrm{Cu}^{\mathrm{II}}\left(\mu_{3}-\mathrm{OH}\right)\right]\left(\mathrm{BAr}_{4}\right)_{3}\left(\mathbf{4 b}-\mathrm{BAr}_{4}{ }_{4}\right) \ldots . . \mathrm{S} 3$

Synthesis and characterization of $\left[\mathbf{T R E N}_{4} \mathrm{Cu}^{\mathrm{I}} \mathrm{Cu}^{\mathrm{I}} \mathrm{Cu}^{\mathrm{I}}\left(\mu_{3}-\mathrm{OH}\right)\right]\left(\mathrm{PF}_{6}\right)_{2}(\mathbf{4 a}) \ldots \ldots \ldots \ldots \ldots \ldots . . . . . . . . . . . . .54$

Synthesis and characterization of $\left[\mathbf{T R E N}_{4} \mathrm{Cu}^{\mathrm{I}} \mathrm{Cu}^{\mathrm{I}} \mathrm{Cu}^{\mathrm{I}}\left(\mu_{3}-\mathrm{OH}\right)\right]\left(\mathrm{BAr}_{4}\right)_{2}\left(\mathbf{4 a}-\mathrm{BAr}_{4}{ }^{\mathrm{F}}\right) \ldots . . . \mathrm{S} 5$

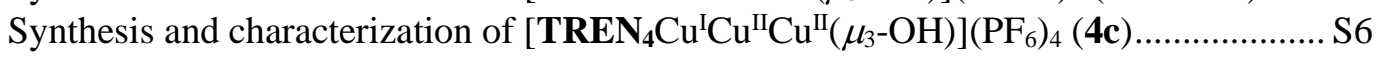

Synthesis and characterization of decamethylferrocenium hexafluorophosphate............S8

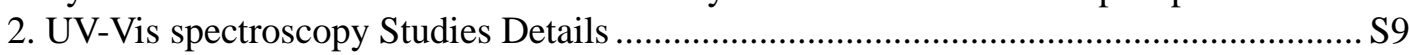

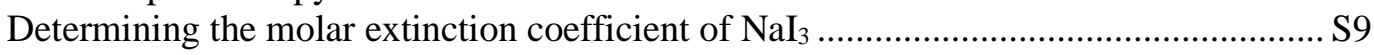

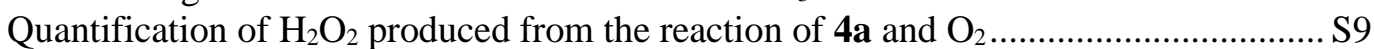

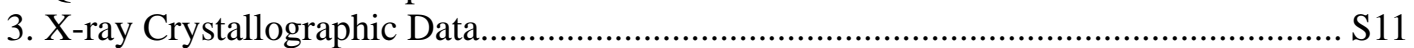

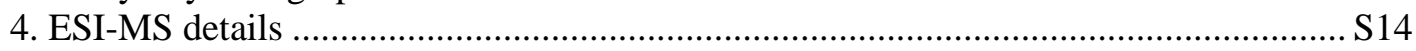

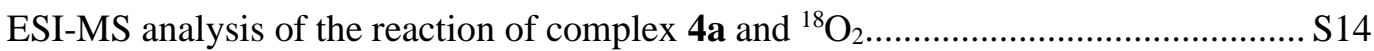

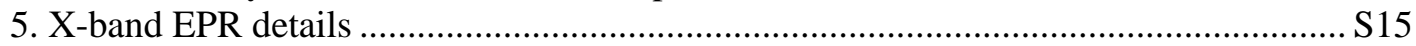

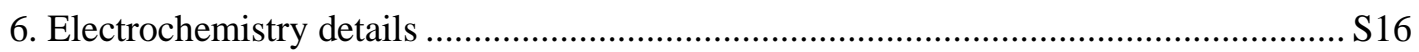

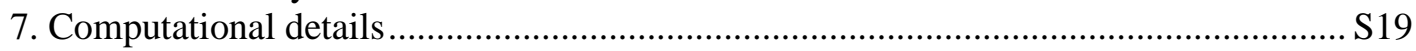

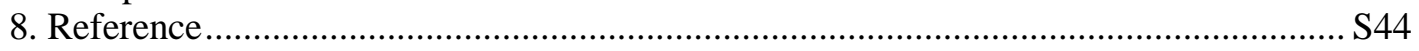

\section{Materials and Methods}

General: All reactions were carried out under a nitrogen atmosphere in an MBraun glovebox or using Schlenk techniques.

Instrumentation: Nuclear magnetic resonance (NMR) spectra were recorded on DXP 400 $\mathrm{MHz}\left({ }^{1} \mathrm{H}: 400 \mathrm{MHz}\right)$ and AVIII $600 \mathrm{MHz}\left({ }^{1} \mathrm{H}: 600 \mathrm{MHz}\right)$ at ambient temperature. Chemical shift values for protons were referenced to the residual proton resonance of acetone- $d_{6}(\delta$ : $2.05 \mathrm{ppm})$ and tetrahydrofuran- $d_{8}$ (THF- $d_{8}, \delta: 1.72 \mathrm{ppm}$ and $\left.3.58 \mathrm{ppm}\right)$. X-ray crystallographic analyses were performed under a cold nitrogen stream (Oxford Cryosystems Cryostream) at $100 \mathrm{~K}\left(\mathbf{4 a}, \mathbf{4 b}, \mathbf{4 c}, \mathbf{4 a}-\mathrm{BAr}_{4}{ }_{4}\right)$ on a Bruker D8 Venture instrument with Mo Ka ra- 
diation source $(\lambda=0.7107 \AA)$ and a Photon II detector. Elemental analyses were performed by Midwest Micro Lab (Indianapolis, IN, http://midwestlab.com/). ESI mass spectra were recorded on a Bruker MicrOTOF. EPR measurements were performed in $4 \mathrm{~mm}$ low-pressure quartz tubes on a Bruker EMXPlus X-band EPR spectrometer equipped with a Coldedge cryostat with small-volume power saturation. Solid-state IR was recorded on a Bruker Alpha II FTIR spectrometer. Cyclic voltammogram was performed using Bio-Logic SAS SP-50 with a glassy carbon working electrode, a platinum wire counter electrode and a $\mathrm{Ag} / \mathrm{Ag}^{+}$reference electrode (a commercial leakless miniature $\mathrm{Ag} / \mathrm{AgCl}$ reference is used for aqueous solution and a $\mathrm{Ag} / \mathrm{AgNO}_{3}(0.01 \mathrm{M})$ reference electrode is used for organic solution).

Materials: Anhydrous acetone and anhydrous methanol were purchased from Acros and Alfa Aesar, respectively, and were used as received. Dichloromethane, acetonitrile, diethyl ether, tetrahydrofuran, and fluorobenzene were dried and degassed under nitrogen using a Pure Process Technologies (PPT, Nashua, NH) solvent purification system, and stored over $4 \AA$ molecular sieves. Acetone- $d_{6}$ (Cambridge Isotope Laboratories, Inc.) was purified by distillation, deoxygenated by three freeze-pump-thaw cycles, and dried over $4 \AA$ molecular sieves prior to use. Tetrahydrofuran- $d_{8}$ (Cambridge Isotope Laboratories, Inc.) was deoxygenated by three freeze-pump-thaw cycles and dried over $4 \AA$ molecular sieves prior to use. Tetrakis(acetonitrile)copper(I) hexafluorophosphate (Sigma-Aldrich), paraformaldehyde (Acros), tris(2-aminoethyl) amine (TREN, TCI), cobaltocene (Strem), tetra-n-butylammonium tetrafluoroborate (Sigma-Aldrich), tetra-n-butylammonium chloride (Combi-Blocks), decamethylferrocene (Sigma-Aldrich), silver hexafluorophosphate (Strem), iodine (VWR), sodium iodide (Sigma-Aldrich), triazabicyclodecene (TBD, Sigma-Aldrich), dioxygen (Praxair), and ${ }^{18} \mathrm{O}$-dioxygen (Sigma-Aldrich) were purchased and used without further purification. Sodium tetrakis[(3,5-trifluoromethyl)phenyl]borate was prepared by a published method. ${ }^{1}$ AcOH (glacial, Fisher) and heptane (anhydrous, Alfa Aesar) were deoxygenated by three freeze-pump-thaw cycles before use.

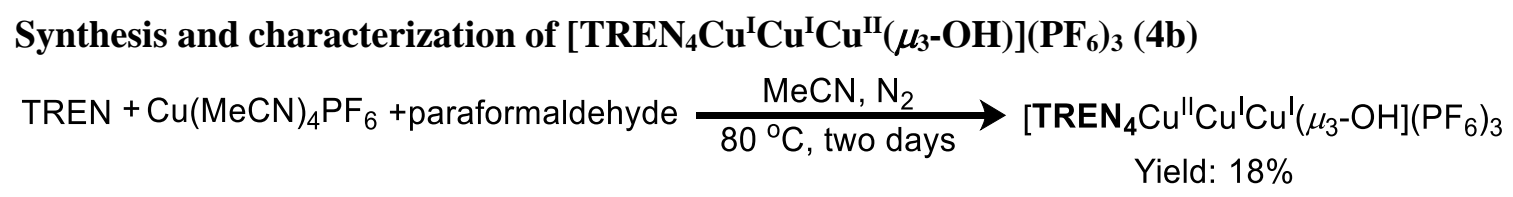

Tetrakis(acetonitrile)copper(I) hexafluorophosphate $(93.3 \mathrm{mg}, 0.251 \mathrm{mmol})$, paraformaldehyde $(150 \mathrm{mg}, 50.0 \mathrm{mmol})$, and acetonitrile $(10 \mathrm{~mL})$ were added to a $20 \mathrm{~mL}$ scintillation vial equipped with a septum under nitrogen atmosphere. Tris(2-aminoethyl) amine (TREN, 0.150 $\mathrm{mL}, 1.00 \mathrm{mmol}$ ) was injected with a syringe. Four other vials with the same suspension were prepared in parallel. The five vials were sealed and heated at $80{ }^{\circ} \mathrm{C}$ with vigorous stirring for two days, during which the solution turned dark brown. After the reaction, the solution was allowed to cool down and transferred back to the glovebox. The dark brown suspension from five vials was combined and filtered under a nitrogen atmosphere. The brown filtrate was dried under vacuum to afford an orange oil-like residue. Dichloromethane $(10 \mathrm{~mL})$ was added to the residue, and the resulting suspension was allowed to sit overnight at room temperature to yield a mixture of a blue solid and a yellow solid, which was collected by filtration and washed with additional dichloromethane $(c a .10 \mathrm{~mL})$, and extracted into acetone $(15 \mathrm{~mL})$. The acetone solution was filtered, and all volatiles were removed under vacuum to yield a blue solid. The product was rewashed with dichloromethane $(c a .10 \mathrm{~mL})$ and dried under vacuum to afford $106.8 \mathrm{mg}$ of $\mathbf{4 b}$ ( $18 \%$ yield). Single crystals of $\mathbf{4 b}$ suitable for X-ray diffraction were obtained by diffusing diethyl ether to an acetone solution of $\mathbf{4 b}$ at $-30{ }^{\circ} \mathrm{C}$.

Elemental analysis, Calcd for $\mathrm{C}_{36} \mathrm{H}_{73} \mathrm{Cu}_{3} \mathrm{~F}_{18} \mathrm{~N}_{16} \mathrm{OP}_{3} \mathrm{C}, 31.52 ; \mathrm{H}, 5.36 ; \mathrm{N}, 16.34$. found $\mathrm{C}$, 31.75; H, 5.39; N, 16.06.

Infrared spectrum (ATR), $\mathrm{vOH}=3440 \mathrm{~cm}^{-1}$ (Figure 6);

UV-Vis spectrum (acetone, Figure S1), $\lambda_{\max }=655 \mathrm{~nm}\left(800 \mathrm{M}^{-1} \mathrm{~cm}^{-1}\right), 790 \mathrm{~nm}\left(870 \mathrm{M}^{-1} \mathrm{~cm}^{-1}\right)$; 
ESI-MS spectrum (Figure S2), M/z = 312.2;

EPR spectrum (acetonitrile, $50 \mathrm{~K}$, Figure $\mathrm{S} 16$ ), $\mathrm{g}_{1}=2.14, \mathrm{~g}_{2}=2.25, \mathrm{~g}_{3}=2.01, \mathrm{~A}_{3}=146 \mathrm{MHz}$.
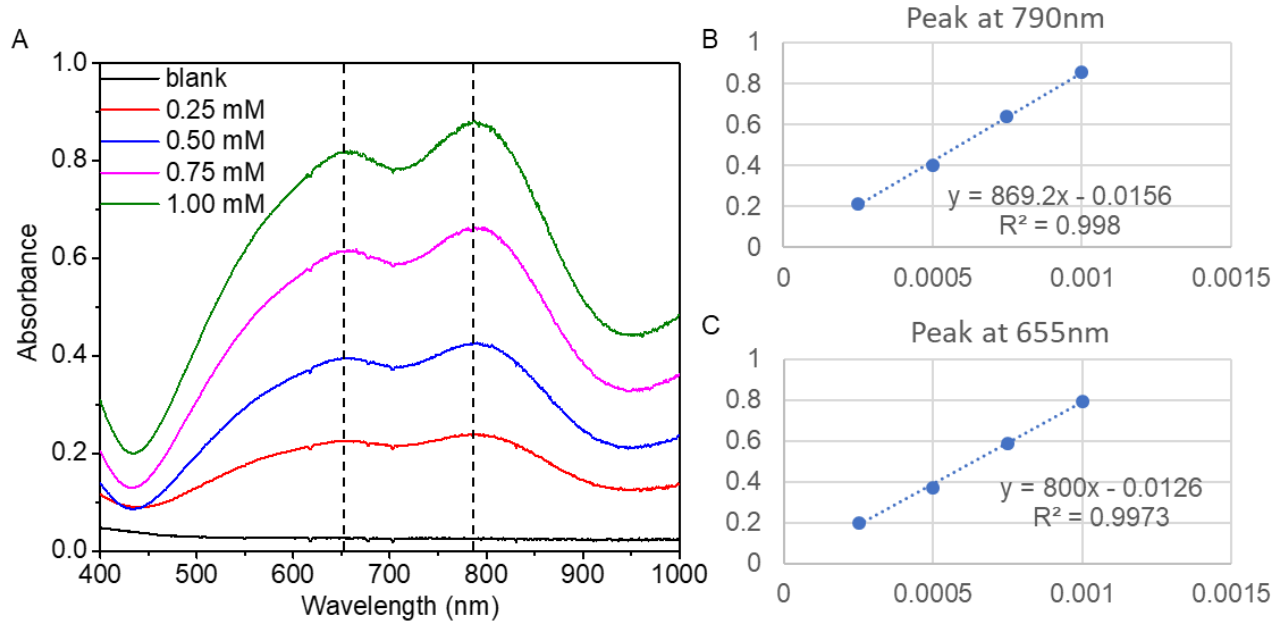

Figure S1. (A) UV-Vis spectra of $\left[\mathbf{T R E N}_{4} \mathrm{Cu}^{\mathrm{I}} \mathrm{Cu}^{\mathrm{I}} \mathrm{Cu}^{\mathrm{II}}\left(\mu_{3}-\mathrm{OH}\right)\right]\left(\mathrm{PF}_{6}\right)_{3}(\mathbf{4 b})$ at various concentration in acetone at room temperature; Beer's law plots for the peak at $790 \mathrm{~nm}(\mathrm{~B}, \varepsilon=870$ $\left.\mathrm{M}^{-1} \mathrm{~cm}^{-1}\right)$ and $655 \mathrm{~nm}\left(\mathrm{C}, \varepsilon=800 \mathrm{M}^{-1} \mathrm{~cm}^{-1}\right)$.

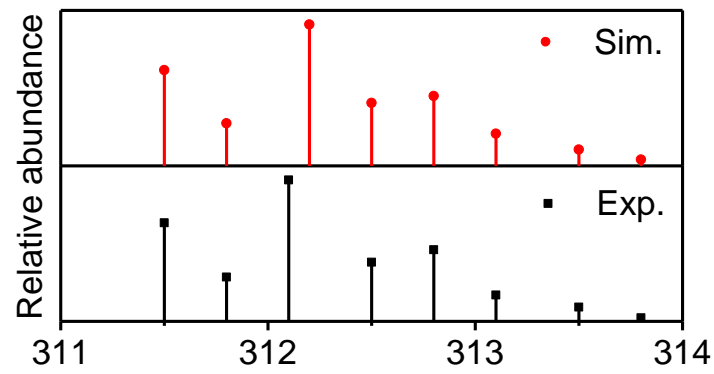

Figure S2. ESI-MS spectrum (MeCN) and simulation of $\left[\mathbf{T R E N}_{4} \mathrm{Cu}^{\mathrm{I}} \mathrm{Cu}^{\mathrm{I}} \mathrm{Cu}^{\mathrm{II}}\left(\mu_{3}-\mathrm{OH}\right)\right]\left(\mathrm{PF}_{6}\right)_{3}$.

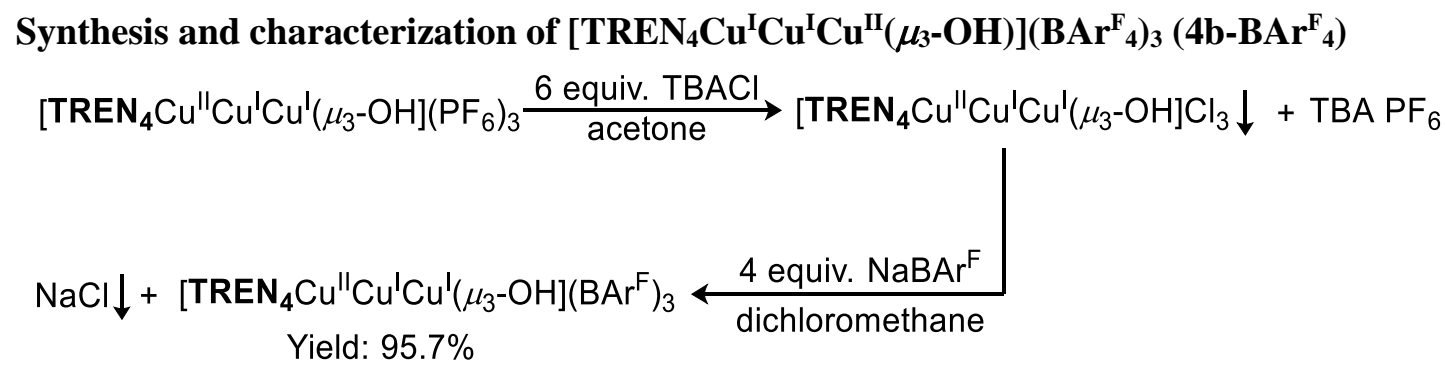

To an acetone $(1 \mathrm{~mL})$ solution of tetra-n-butylammonium chloride $(60.8 \mathrm{mg}, 0.219 \mathrm{mmol})$, an acetone $(4 \mathrm{~mL})$ solution of $\left[\mathbf{T R E N}_{4} \mathrm{Cu}^{\mathrm{I}} \mathrm{Cu}^{\mathrm{I}} \mathrm{Cu}^{\mathrm{II}}\left(\mu_{3}-\mathrm{OH}\right)\right]\left(\mathrm{PF}_{6}\right)_{3}(40.0 \mathrm{mg}, 0.0292 \mathrm{mmol})$ was added dropwise with stirring. A blue precipitate was formed immediately and collected by filtration. After being washed by acetone (ca. $2 \mathrm{~mL}$ ), the blue solid was dried under vacuum. Then, a dichloromethane $(3 \mathrm{~mL})$ suspension of the obtained blue solid was added to a dichloromethane $(2 \mathrm{~mL})$ suspension of sodium tetrakis[(3,5-trifluoromethyl)phenyl]borate $(103.5 \mathrm{mg}, 0.117 \mathrm{mmol})$. The mixture was allowed to stir at room temperature overnight. After filtration, the blue filtrate was collected and dried under vacuum. The obtained blue solid was washed with diethyl ether ( $c a .3 \mathrm{~mL}$, three times) and dried under vacuum to afford the desired product $\mathbf{4 b}-\mathrm{BAr}_{4}(98.3 \mathrm{mg}, 96 \%$ yield $)$.

Elemental analysis, Calcd for $\mathrm{C}_{132} \mathrm{H}_{109} \mathrm{~B}_{3} \mathrm{Cu}_{3} \mathrm{~F}_{72} \mathrm{~N}_{16} \mathrm{O} \mathrm{C}, 44.96 ; \mathrm{H}, 3.12 ; \mathrm{N}, 6.36$. found $\mathrm{C}$, 
Synthesis and characterization of $\left[\mathrm{TREN}_{4} \mathrm{Cu}^{\mathrm{I}} \mathrm{Cu}^{\mathrm{I}} \mathrm{Cu}^{\mathrm{I}}\left(\mu_{3}-\mathrm{OH}\right)\right]\left(\mathrm{PF}_{6}\right)_{2}(4 \mathrm{a})$

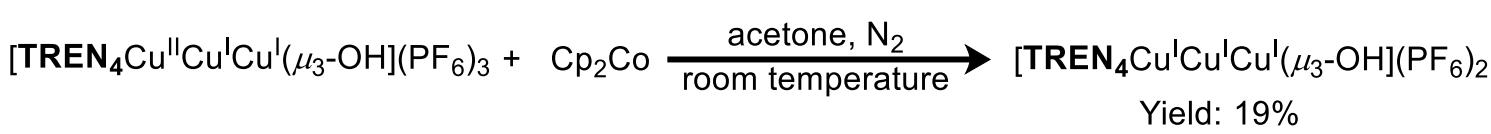

To an acetone $(6 \mathrm{~mL})$ solution of $\left[\mathbf{T R E N}_{4} \mathrm{Cu}^{\mathrm{I}} \mathrm{Cu}^{\mathrm{I}} \mathrm{Cu}^{\mathrm{II}}\left(\mu_{3}-\mathrm{OH}\right)\right]\left(\mathrm{PF}_{6}\right)_{3}(\mathbf{4 b}, 40.0 \mathrm{mg}, 0.0292$ $\mathrm{mmol})$, an acetone $(2 \mathrm{~mL})$ solution of $\mathrm{CoCp}_{2}(6.1 \mathrm{mg}$, and $0.0321 \mathrm{mmol}, 1.1 \mathrm{eq})$ was added under nitrogen atmosphere. The mixture was stirred at room temperature for five minutes, during which the color of the solution turns yellow. All volatiles were removed under vacuum, and the yielded yellow residue was washed by THF (ca.15 mL). After dried under vacuum, the solid was dissolved in acetone $(c a .1 .5 \mathrm{ml})$. Slow diffusion of diethyl ether to the acetone solution at $-30{ }^{\circ} \mathrm{C}$ afford colorless crystals of $\mathbf{4 a}(6.7 \mathrm{mg}$, yield 19\%) suitable for XRD (Figure S11). ${ }^{1} \mathrm{H}$ NMR analysis of the crystals (Figure S3) shows a mixture of 4a (marked with blue dots) and a small amount of impurity that appears to be the protonated species $[\mathbf{4 a}+\mathrm{H}]$ with sharp resonances at 9.20, 4.34, 3.30, 2.72, 2.45, and $2.36 \mathrm{ppm}$ (marked with red dots, Figure S3). We believe that the protonation of $4 \mathbf{a}$ was due to the residual water in acetone- $d_{6}$, which cannot be completely removed without causing the decomposition of acetone- $d_{6}$. Unfortunately, we were unable to obtain a solution of $\mathbf{4 a}$ in THF- $d_{8}$ due to its low solubility. Other NMR solvents, e.g. acetonitrile- $d_{3}$, cause rapid decomposition of $\mathbf{4 a}$ back to $\mathbf{4 b}$. To confirm these sharp resonances $(9.20,4.34,3.30,2.72,2.45$, and $2.36 \mathrm{ppm})$ are from protonated $\mathbf{4 a}$, we prepared the $\mathrm{BAr}_{4}{ }_{4}$ analog $\mathbf{4 a}-\mathrm{BAr}_{4}{ }_{4}$, which can be dissolved and analyzed in THF- $d_{8}$ (infra vide).

Infrared spectrum, $\mathrm{vOH}=3516 \mathrm{~cm}^{-1}$ (Figure 6).

ণั?

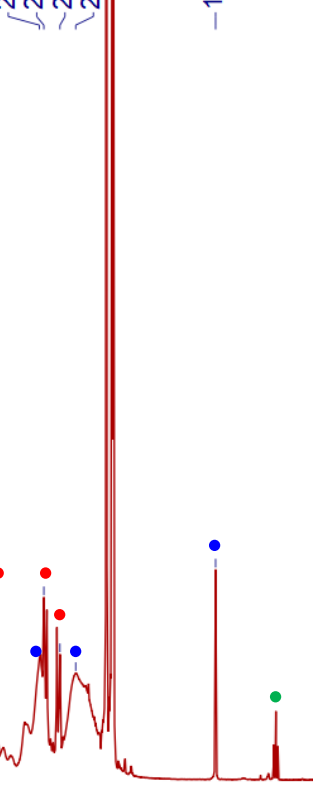

$\begin{array}{lllllllllllllllll}9.0 & 8.5 & 8.0 & 7.5 & 7.0 & 6.5 & 6.0 & 5.5 & \begin{array}{c}5.0 \\ \mathrm{ppm}\end{array} & 4.5 & 4.0 & 3.5 & 3.0 & 2.5 & 2.0 & 1.5 & 1.0\end{array}$

Figure S3. ${ }^{1} \mathrm{H}$ NMR spectrum (600 MHz, acetone- $d_{6}$ ) of 4 a (blue dots). The peaks marked with green dots are from residual diethyl ether. The peaks marked with red dots are from protonated $\mathbf{4 a}$. 


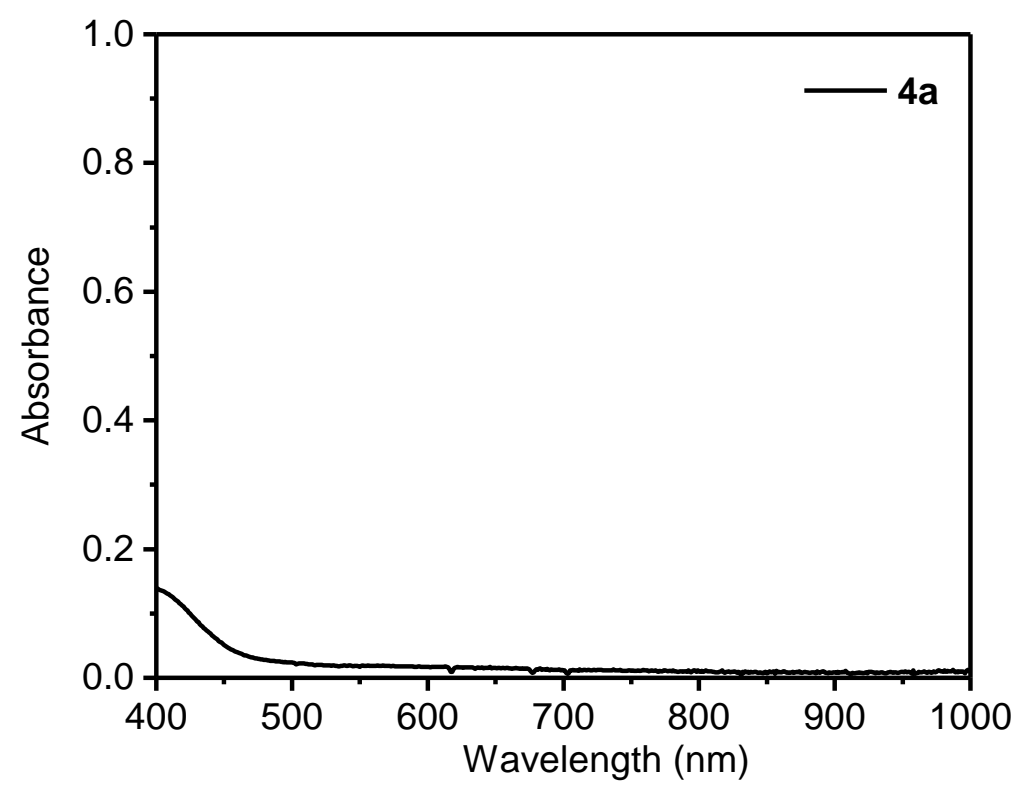

Figure S4. UV-Vis spectrum of $\left[\mathbf{T R E N}_{4} \mathrm{Cu}^{\mathrm{I}} \mathrm{Cu}^{\mathrm{I}} \mathrm{Cu}^{\mathrm{I}}\left(\mu_{3}-\mathrm{OH}\right)\right]\left(\mathrm{PF}_{6}\right)_{2}(\mathbf{4 a})$ in acetone at room temperature. The UV-Vis sample was generated in-situ from the treatment of [TREN $\left.\mathrm{Cu}^{\mathrm{I}} \mathrm{Cu}^{\mathrm{I}} \mathrm{Cu}^{\mathrm{II}}\left(\mu_{3}-\mathrm{OH}\right)\right]\left(\mathrm{PF}_{6}\right)_{3}(4 \mathbf{b})$ with one equivalent of $\mathrm{Cp}_{2} \mathrm{Co}$.

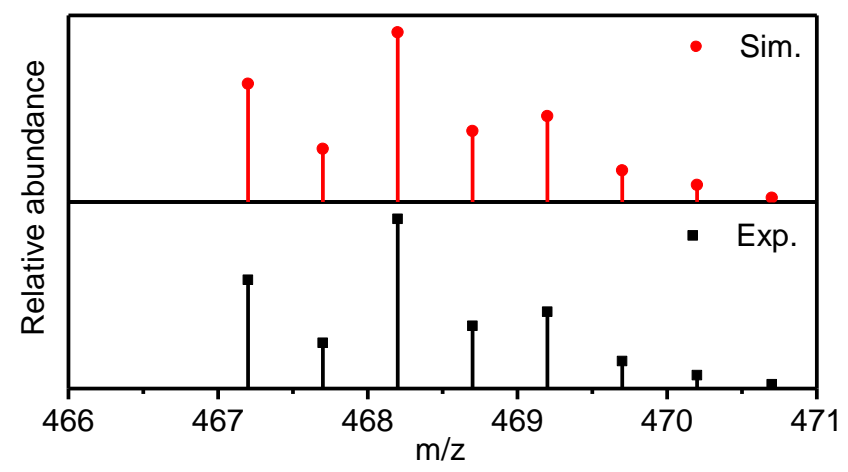

Figure S5. ESI-MS spectrum $(\mathrm{MeCN})$ and simulation of $\left[\mathbf{T R E N}_{4} \mathrm{Cu}^{\mathrm{I}} \mathrm{Cu}^{\mathrm{I}} \mathrm{Cu}^{\mathrm{I}}\left(\mu_{3}-\mathrm{OH}\right)\right]\left(\mathrm{PF}_{6}\right)_{2}$ (4a).

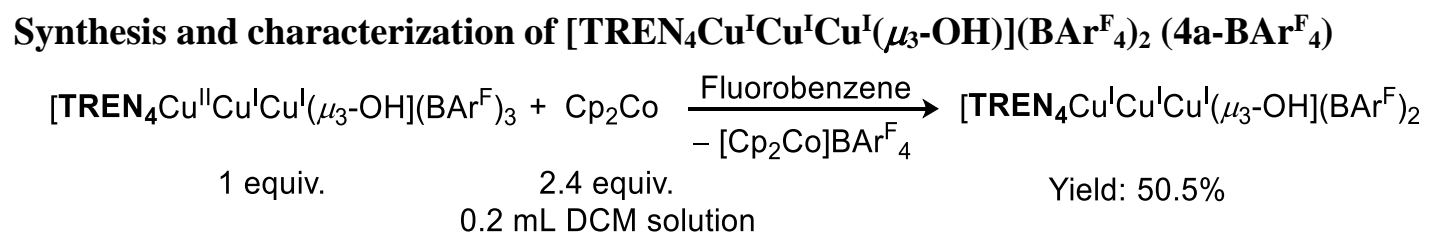

To a suspension of $\mathbf{4 b}-\mathrm{BAr}_{4}{ }_{4}(10.0 \mathrm{mg}, 0.00284 \mathrm{mmol})$ in fluorobenzene $(1 \mathrm{~mL})$, a dichloromethane $(0.2 \mathrm{~mL})$ solution of $\mathrm{Cp}_{2} \mathrm{Co}(1.3 \mathrm{mg}, 0.0068 \mathrm{mmol})$ was added with stirring. The blue $4 \mathbf{b}-\mathrm{BAr}_{4} \mathrm{~F}_{4}$ was gradually dissolved and the solution turned yellow. After filtration, the yellow filtrate was allowed to sit at room temperature overnight. Colorless needle-like crystals of $4 \mathbf{a}-\mathrm{BAr}^{\mathrm{F}}{ }_{4}$ suitable for single-crystal $\mathrm{X}$-ray diffraction were obtained. The mother liquid was pipetted out and the crystals were washed by fluorobenzene $(c a .5 \mathrm{~mL})$ for three times. The obtained white solid was dissolved in THF $(1.5 \mathrm{~mL})$ and treated with triazabicyclodecene ( $2.0 \mathrm{mg}, 0.014 \mathrm{mmol}$ ). After about one minute, the resulting suspension was filtered, and the filtrate was dried under vacuum. The obtained solid was washed with fluorobenzene ( $c a .8$ $\mathrm{mL}$, five times) and dried under vacuum to afford $4 \mathbf{a}-\mathrm{BAr}^{\mathrm{F}}{ }_{4}(3.8 \mathrm{mg}, 51 \%$ yield). (Figure 
S12). ${ }^{1} \mathrm{H}$ NMR (600 MHz, THF- $d_{8}$, Figure S6) $\delta 7.79$ (br, 16H), 7.58 (br, 8H), 3.98 (br, 12H), 3.28 (br, 12H), 2.92 (br, 12H), 2.44 (br, 12H), 2.19 (br, 24H), 1.35 (s, 1H);

Elemental analysis, Calcd for $\mathrm{C}_{100} \mathrm{H}_{97} \mathrm{~B}_{2} \mathrm{Cu}_{3} \mathrm{~F}_{48} \mathrm{~N}_{16} \mathrm{O}$ C, 45.10; H, 3.67; N, 8.42. found $\mathrm{C}$, $45.17 ; \mathrm{H}, 3.84 ; \mathrm{N}, 8.45$.
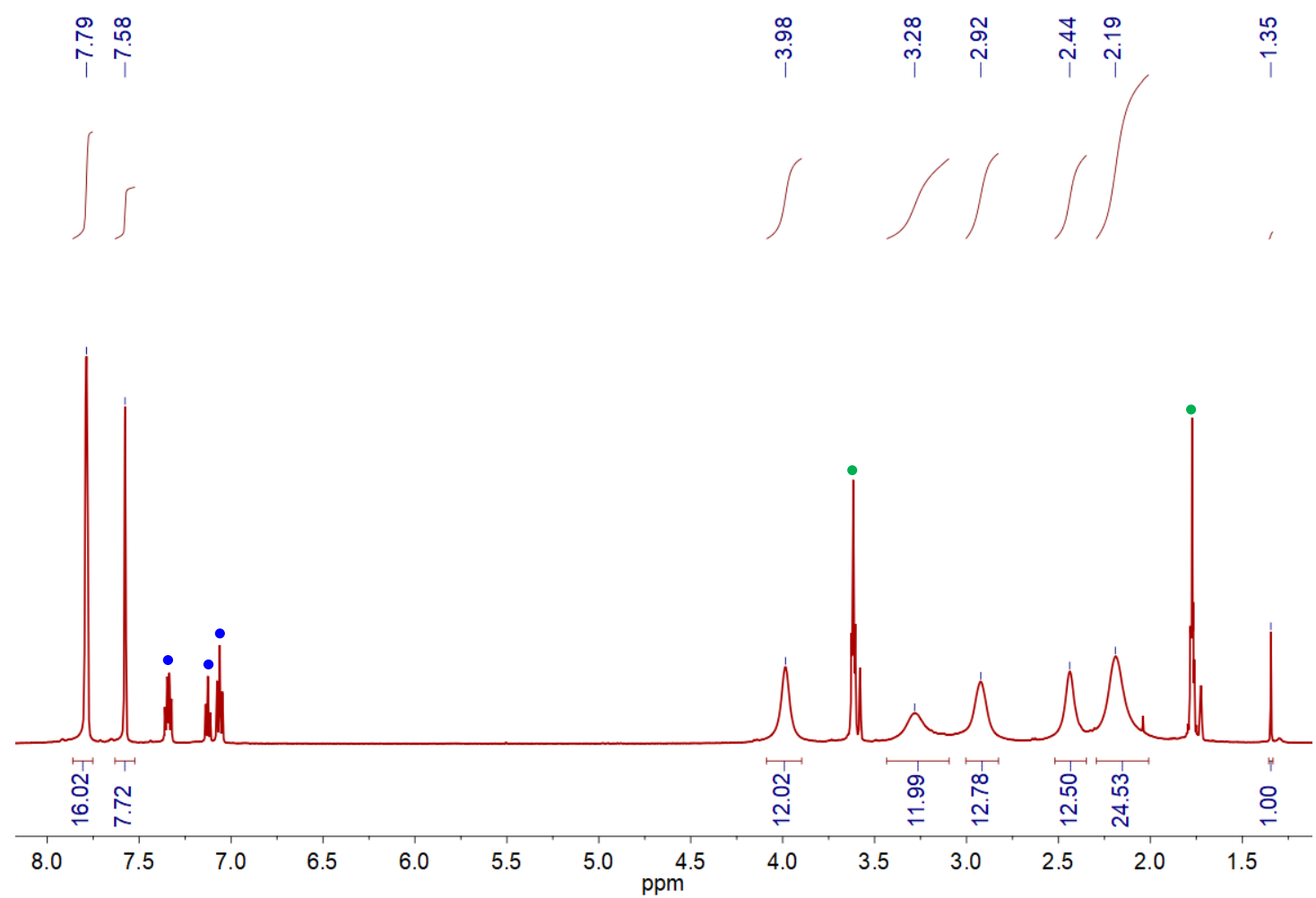

Figure S6. ${ }^{1} \mathrm{H}$ NMR spectrum $\left(600 \mathrm{MHz}, \mathrm{THF}-d_{8}\right)$ of $\mathbf{4 a}-\mathrm{B} A \mathrm{r}^{\mathrm{F}}$. The peaks marked with blue dots are from residual fluorobenzene. The peaks marked with green spots are from residual THF.

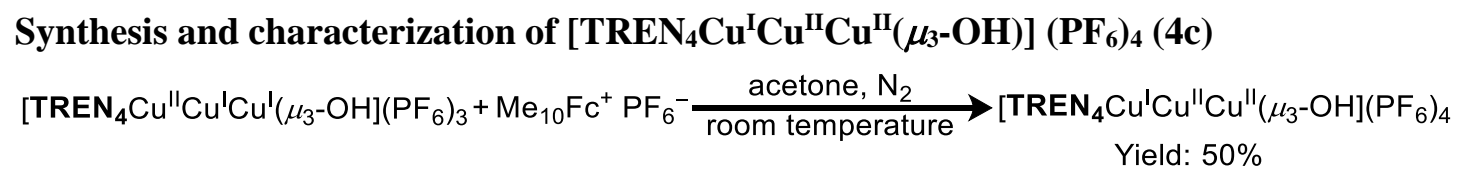

To an acetone $(3 \mathrm{~mL})$ solution of $\left[\mathbf{T R E N}_{4} \mathrm{Cu}^{\mathrm{I}} \mathrm{Cu}^{\mathrm{I}} \mathrm{Cu}^{\mathrm{II}}\left(\mu_{3}-\mathrm{OH}\right)\right]\left(\mathrm{PF}_{6}\right)_{3}(20.0 \mathrm{mg}, 0.0140 \mathrm{mmol})$, an acetone $(4 \mathrm{~mL})$ solution of decamethylferrocenium hexafluorophosphate $(9.4 \mathrm{mg}, 0.020$ mmol) was added under nitrogen atmosphere. The mixture was allowed to stir at room temperature for ten minutes. The solution was dried under vacuum and the yielded solid was re-dissolved in acetone ( $c a .1 \mathrm{~mL})$. THF $(c a .15 \mathrm{~mL})$ was then added to the acetone solution with stirring. The obtained suspension was filtered and the dark blue precipitate was collected and dried under vacuum to afford $\mathbf{4 c}(10.6 \mathrm{mg}, 50 \%$ yield $)$ as a dark blue powder.

Elemental analysis, Calcd for $4 \mathbf{c} \bullet\left(\mathrm{CH}_{3} \mathrm{C}(\mathrm{O}) \mathrm{CH}_{3}\right)_{2}, \mathrm{C}_{42} \mathrm{H}_{85} \mathrm{Cu}_{3} \mathrm{~F}_{24} \mathrm{~N}_{16} \mathrm{OP}_{4}: \mathrm{C}, 30.90 ; \mathrm{H}, 5.25 ; \mathrm{N}$, 13.73. found $\mathrm{C}, 30.05 ; \mathrm{H}, 5.26 ; \mathrm{N}, 13.70$.

UV-Vis spectrum (acetone, Figure S7), $\lambda_{\max }=680 \mathrm{~nm}\left(970 \mathrm{M}^{-1} \mathrm{~cm}^{-1}\right), 850 \mathrm{~nm}\left(1250 \mathrm{M}^{-1} \mathrm{~cm}^{-1}\right)$; Infrared spectrum, $\mathrm{vOH}=3372 \mathrm{~cm}^{-1}$ (Figure 6). 


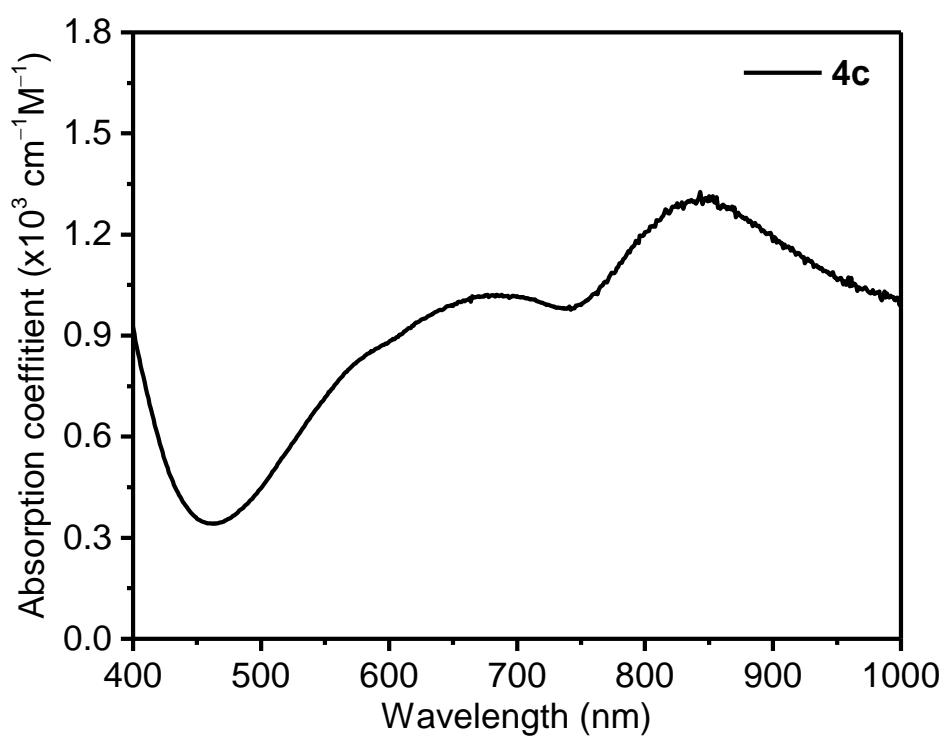

Figure S7. UV-Vis spectrum of $\left[\mathbf{T R E N}_{4} \mathrm{Cu}^{\mathrm{I}} \mathrm{Cu}^{\mathrm{II}} \mathrm{Cu}^{\mathrm{II}}\left(\mu_{3}-\mathrm{OH}\right)\right]\left(\mathrm{PF}_{6}\right)_{4}$ in acetonitrile at room temperature. Two maxima at $680 \mathrm{~nm}$ and $850 \mathrm{~nm}$ were observed.

In order to obtain crystals of $\left[\mathbf{T R E N}_{4} \mathrm{Cu}^{\mathrm{I}} \mathrm{Cu}^{\mathrm{II}} \mathrm{Cu}^{\mathrm{II}}\left(\mu_{3}-\mathrm{OH}\right)\right]^{4+}$ for single-crystal X-ray diffraction analysis, [TREN $\left.{ }_{4} \mathrm{Cu}^{\mathrm{I}} \mathrm{Cu}^{\mathrm{II}} \mathrm{Cu}^{\mathrm{II}}\left(\mu_{3}-\mathrm{OH}\right)\right]\left(\mathrm{PF}_{6}\right)_{4}(10.0 \mathrm{mg}, 0.00659 \mathrm{mmol})$ and tetra-n-butylammonium tetrafluoroborate $\left(\mathrm{TBABF}_{4}, 2.0 \mathrm{mg}, 0.0060 \mathrm{mmol}\right)$ was dissolved in acetone $(\mathrm{ca} .1 \mathrm{~mL})$. Slow diffusion of diethyl ether to the mixture of [TREN $\left.{ }_{4} \mathrm{Cu}^{\mathrm{I}} \mathrm{Cu}^{\mathrm{II}} \mathrm{Cu}^{\mathrm{II}}\left(\mu_{3}-\mathrm{OH}\right)\right]\left(\mathrm{PF}_{6}\right)_{4}$ and $\mathrm{TBABF}_{4}$ at $-30^{\circ} \mathrm{C}$ afford single crystals of $\left[\mathrm{TREN}_{4} \mathrm{Cu}^{\mathrm{I}} \mathrm{Cu}^{\mathrm{II}} \mathrm{Cu}^{\mathrm{II}}\left(\mu_{3}-\mathrm{OH}\right)\right]\left(\mathrm{PF}_{6}\right)\left(\mathrm{BF}_{4}\right)_{3}$ (Figure $\left.\mathrm{S} 13\right)$.

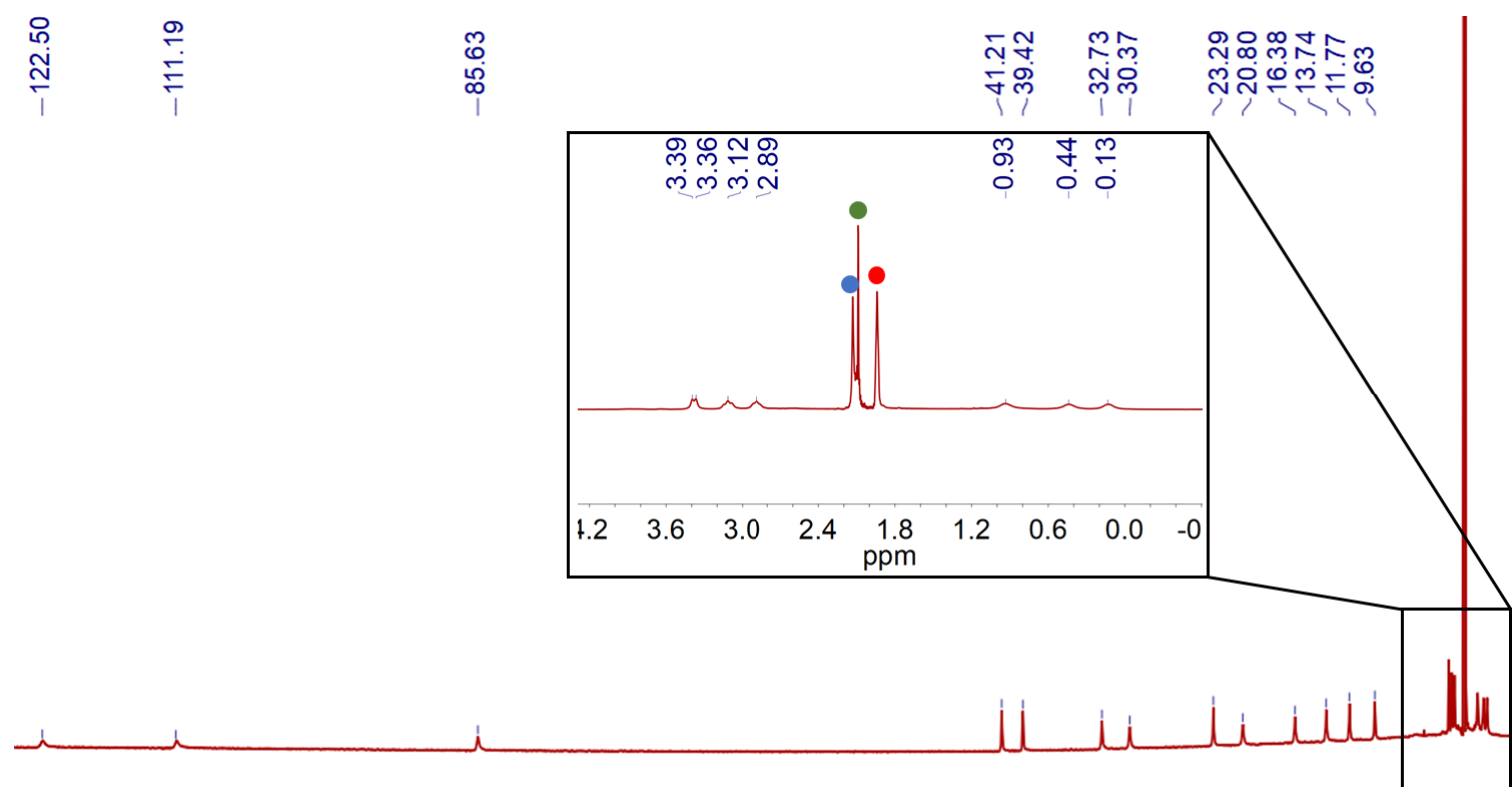

$\begin{array}{lllllllllllllllllllllllll}120 & 115 & 110 & 105 & 100 & 95 & 90 & 85 & 80 & 75 & 70 & 65 & \mathbf{6 0} & 55 & 50 & 45 & 40 & 35 & 30 & 25 & 20 & 15 & 10 & 5 & 0\end{array}$

Figure S8. ${ }^{1} \mathrm{H}$ NMR $\left(400 \mathrm{MHz}, \mathrm{CD}_{3} \mathrm{CN}\right)$ spectrum of $\left[\mathbf{T R E N}_{4} \mathrm{Cu}^{\mathrm{I}} \mathrm{Cu}^{\mathrm{II}} \mathrm{Cu}^{\mathrm{II}}\left(\mu_{3}-\mathrm{OH}\right)\right]\left(\mathrm{PF}_{6}\right)_{4}(\mathbf{4 c})$. 
The peak marked with a red dot is from residual $\mathrm{CD}_{2} \mathrm{HCN}$ from the NMR solvent. The peak marked with a green dot is from residual acetone. The peak marked with a green dot is from residual water.

\section{Synthesis and characterization of decamethylferrocenium hexafluorophosphate}

$$
\begin{array}{ccc}
\mathrm{Me}_{10} \mathrm{Fc}+\mathrm{AgPF}_{6} \frac{\text { acetone, } \mathrm{N}_{2}}{\text { room temperature }} \mathrm{Me}_{10} \mathrm{Fc}^{+} \mathrm{PF}_{6}{ }^{-}+\mathrm{Ag} \\
\text { Yield: } 80 \%
\end{array}
$$

To an acetone suspension $(5 \mathrm{~mL})$ of decamethylferrocene $(154.6 \mathrm{mg}, 0.4738 \mathrm{mmol})$, an acetone solution $(2 \mathrm{~mL})$ of $\mathrm{AgPF}_{6}(100.0 \mathrm{mg}, 0.3955 \mathrm{mmol})$ was added dropwise with stirring. The obtained mixture was allowed to stir at room temperature for three hours. After filtration, the green filtrate was collected and dried under vacuum. The green-yellow solid was then dissolved in acetone $(c a .5 \mathrm{~mL})$. Diethyl ether $(c a .15 \mathrm{~mL})$ was added to the acetone solution to precipitate out the product. The green solid was collected with filtration and dried under vacuum. Block crystals of the product were obtained by diffusing diethyl ether into an acetone solution $(5 \mathrm{~mL})$ at room temperature overnight (149.9 $\mathrm{mg}$, Yield $80.3 \%)$.

Elemental analysis, Calcd for $\mathrm{C}_{20} \mathrm{H}_{30} \mathrm{~F}_{6} \mathrm{FeP} \mathrm{C}, 50.97 ; \mathrm{H}, 6.42$ found $\mathrm{C}, 51.42 ; \mathrm{H}, 6.38$. 


\section{UV-Vis spectroscopy Studies Details}

Determining the molar extinction coefficient of $\mathrm{NaI}_{3}$ in an acetone/heptane (2:3) mixture
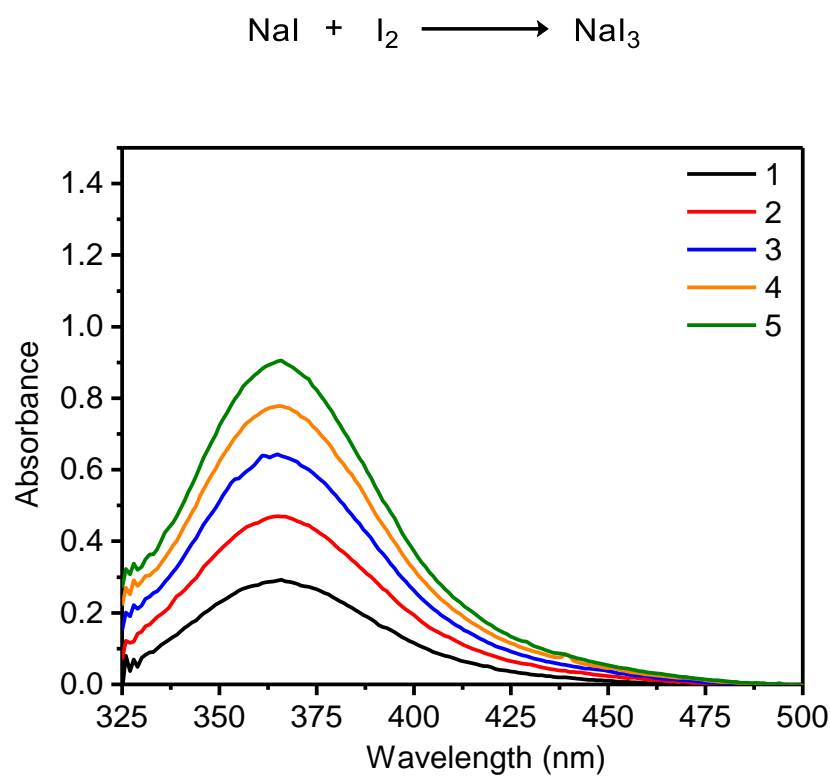

Figure S9. Solutions of $\mathrm{NaI}_{3}$ with various concentrations were prepared by adding a solution of $\mathrm{I}_{2}(0.2 \mathrm{~mL}, 1.2 \mathrm{mM})$ to $\mathrm{NaI}(2 \mathrm{~mL}, 50 \mathrm{mM}$, excess) in acetone/heptane (2:3) sequentially. The UV-Vis traces of the solutions were recorded at $0.0109 \mathrm{mM}$ (trace 1), $0.0200 \mathrm{mM}$ (trace 2), $0.0277 \mathrm{mM}$ (trace 3), $0.0343 \mathrm{mM}$ (trace 4), and $0.0400 \mathrm{mM}$ (trace 5). The molar extinction coefficient of $\mathrm{NaI}_{3}$ at $364 \mathrm{~nm}$ was calculated as $2.13 \times 10^{4} \mathrm{~cm}^{-1} \mathrm{M}^{-1}$.

Quantification of $\mathrm{H}_{2} \mathrm{O}_{2}$ produced from the reaction of $4 \mathrm{a}$ and $\mathrm{O}_{2}$

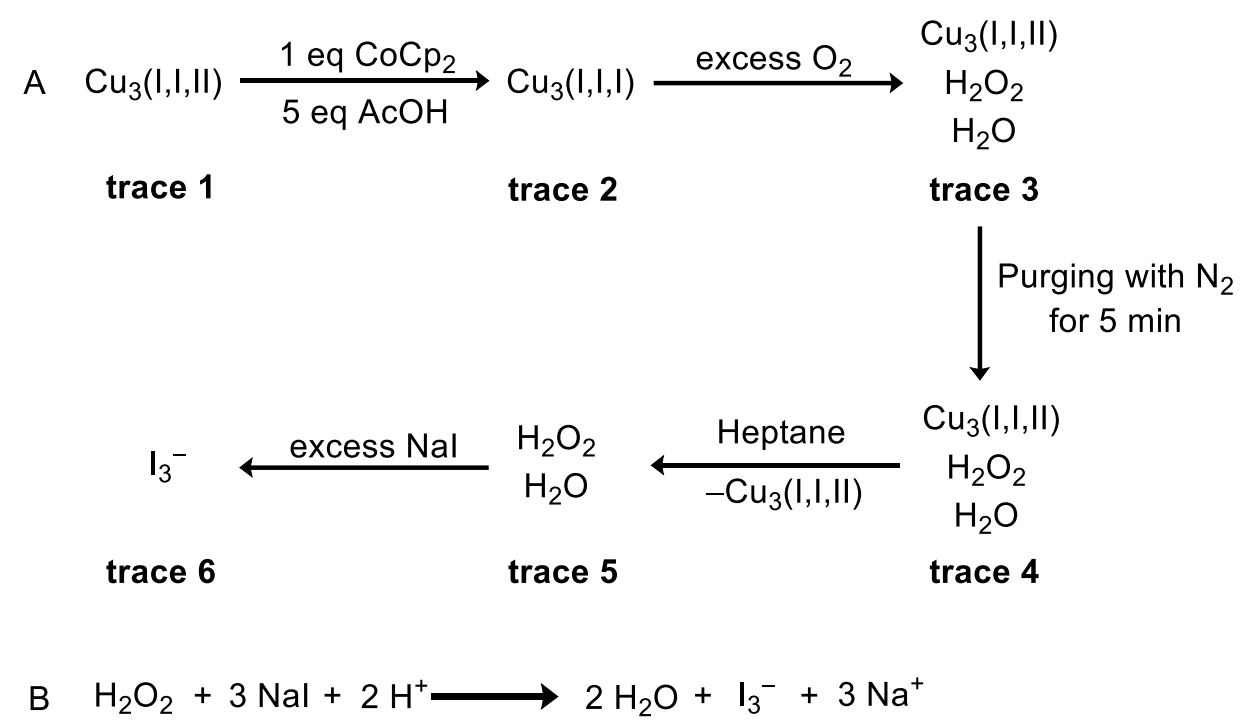

Scheme S1. (A) $\mathrm{H}_{2} \mathrm{O}_{2}$ quantification from the stoichiometric reaction between $4 \mathbf{a}$ and $\mathrm{O}_{2}$. (B) The reaction of $\mathrm{H}_{2} \mathrm{O}_{2}$ and $\mathrm{NaI}$.

In glovebox, an acetone solution of [TREN $\left.{ }_{4} \mathrm{Cu}^{\mathrm{I}} \mathrm{Cu}^{\mathrm{I}} \mathrm{Cu}^{\mathrm{II}}\left(\mu_{3}-\mathrm{OH}\right)\right]\left(\mathrm{PF}_{6}\right)_{3}(\mathbf{4 b}, 1.4 \mathrm{mg}, 1.0 \mu \mathrm{mol}$, $2.00 \mathrm{~mL}, 0.5 \mathrm{mM}$ ) was transferred to a Schlenk quartz cuvette. The cuvette was sealed and transferred to the UV-Vis spectrometer (Figure S9, trace 1). Under nitrogen protection, an ac- 
etone solution of $\mathrm{Cp}_{2} \mathrm{Co}(0.19 \mathrm{mg}, 1.0 \mu \mathrm{mol}, 0.500 \mathrm{~mL}$ acetone $)$ and acetic acid $(0.30 \mathrm{mg}, 5.0$ umol, 5 equiv., $0.500 \mathrm{~mL}$ acetone) were injected to the cuvette. The $790 \mathrm{~nm}$ and $655 \mathrm{~nm}$ bands of complex $\mathbf{4 b}\left(\mathrm{Cu}^{\mathrm{II}} \mathrm{Cu}^{\mathrm{I}} \mathrm{Cu}^{\mathrm{I}}\right)$ were bleached instantaneously (Figure $\mathrm{S} 10$, trace 2, Scheme 1), indicating the formation of complex $4 \mathbf{a}\left(\mathrm{Cu}^{\mathrm{I}} \mathrm{Cu}^{\mathrm{I}} \mathrm{Cu}^{\mathrm{I}}\right)$. Oxygen gas $(0.500 \mathrm{ml}, 20.5$ $\mu$ mol, 20.5 equiv.) was injected to the cuvette (Figure S10, trace 3). The progress of oxygen reduction reaction was monitored by taking a UV-Vis spectrum every 60 seconds. Two bands at $790 \mathrm{~nm}$ and $655 \mathrm{~nm}$ grew in over 5 minutes, indicating the reformation of complex $\mathbf{4 b}$ $\left(\mathrm{Cu}^{\mathrm{II}} \mathrm{Cu}^{\mathrm{I}} \mathrm{Cu}^{\mathrm{I}}\right)$ in $96 \%$ spectroscopic yield. The solution in the Schlenk quartz cuvette was purged with $\mathrm{N}_{2}$ for five minutes to remove the excess oxygen (Figure S10, trace 4). The cuvette was sealed and transferred back into glovebox. The solution in cuvette was transferred to a scintillation vial. The cuvette was washed with additional acetone $(1 \mathrm{~mL})$ to ensure complete transfer. Additional acetone $(0.354 \mathrm{~mL}$, calculated based on absorbance increase at 790 $\mathrm{nm}$ after purging) was added to the scintillation vial in order to compensate the solvent loss during the $\mathrm{N}_{2}$ purging process. To the combined acetone solution, heptane $(6 \mathrm{ml})$ was added in order to precipitate out all the copper complexes. The obtained suspension was then filtered, and the filtrate $(2 \mathrm{~mL})$ was transferred to a new Schlenk quartz cuvette (Figure S10, trace 5). Acetone/heptane (2:3) solution of NaI $(7.5 \mathrm{mg}, 50 \mu \mathrm{mol}, 0.500 \mathrm{~mL})$ was injected to the solution in the cuvette (Figure S10, trace 6). The reaction between $\mathrm{H}_{2} \mathrm{O}_{2}$ and $\mathrm{NaI}$ affords $\mathrm{I}_{3}{ }^{-}$ (Scheme S1, B), the yield of which can be determined by its characteristic absorbance at $\lambda_{\max }$ $=364 \mathrm{~nm}\left(\varepsilon=2.1 \times 10^{4} \mathrm{M}^{-1} \mathrm{~cm}^{-1}\right)$. The $\mathrm{H}_{2} \mathrm{O}_{2}$ quantification results from three independent trials are summarized in Table $\mathrm{S} 1$.

\begin{tabular}{|c|c|c|c|c|}
\hline Entry & Experiment 1 & Experiment 2 & Experiment 3 & average \\
\hline Absorbance $/ \mathrm{I}_{3}^{-}$ & 0.817 & 0.813 & 0.847 & 0.826 \\
\hline Amount / $\mathrm{mmol}^{-}$ & $9.57 \times 10^{-5}$ & $9.52 \times 10^{-5}$ & $9.92 \times 10^{-5}$ & $9.67 \times 10^{-5}$ \\
\hline Yield of $\mathrm{H}_{2} \mathrm{O}_{2}$ & $96 \%$ & $95 \%$ & $99 \%$ & $97 \%$ \\
\hline
\end{tabular}

Table S1. Yields of $\mathrm{H}_{2} \mathrm{O}_{2}$ in three independent trials.

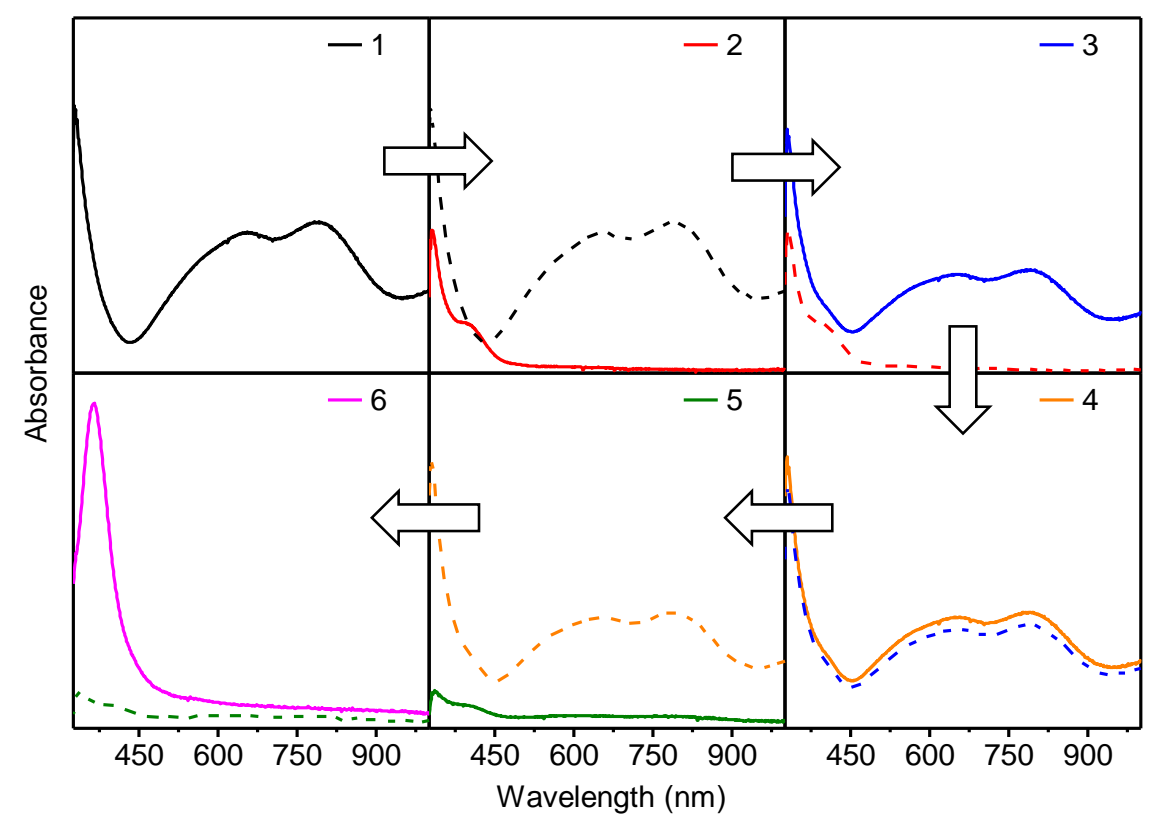

Figure S10. UV-Vis traces for $\mathrm{H}_{2} \mathrm{O}_{2}$ quantification. The absorbances of the spectra were normalized based on solution volume to account for dilution. 


\section{X-ray Crystallographic Data}

The single crystal X-ray diffraction studies were carried out on a Bruker Kappa Photon II CPAD diffractometer equipped with $\mathrm{Cu} \mathrm{K}_{\alpha}$ radiation $(\lambda=1.54178)$ for $\mathbf{4 a}$, a Bruker Kappa Photon II CPAD diffractometer equipped with Mo $\mathrm{K}_{\alpha}$ radiation $(\lambda=0.71073 \AA)$ for $\mathbf{4 b}$, and a Nonius Kappa diffractometer equipped with a Bruker APEX-II CCD and Mo $\mathrm{K}_{\alpha}$ radiation $(\lambda$ $=0.71073 \AA$ ) for $\mathbf{4 c}$. Crystals were mounted on MiTeGen Micromounts with Paratone oil, and data were collected in a nitrogen gas stream at $100 \mathrm{~K}$. The data were integrated using the Bruker SAINT software program and scaled using the SADABS software program. Solution by direct methods (SHELXT) produced a complete phasing model for refinement. All nonhydrogen atoms were refined anisotropically by full-matrix least-squares (SHELXL-2014). All carbon bonded hydrogen atoms were placed using a riding model. Their positions were constrained relative to their parent atom using the appropriate HFIX command in SHELXL-2014. Due to the disorder of the $\mathrm{Cu}$ positions in the structure, the hydroxide hydrogen atoms were placed at idealized locations and restrained using DFIX commands to fit to the disorder model of each structure. Their thermals were fixed to that of the parent oxygen atom. Platon SQUEEZE was used to remove the electron density from the lattice due to the disordered solvent contribution. $\mathbf{4 a}$ and $\mathbf{4 b}$ both had 4 voids with 34 electrons in each. $\mathbf{4 c}$ had 2 large voids of 600 electrons. In all cases, the disordered solvent appeared to be a mixture of acetone and diethyl ether.

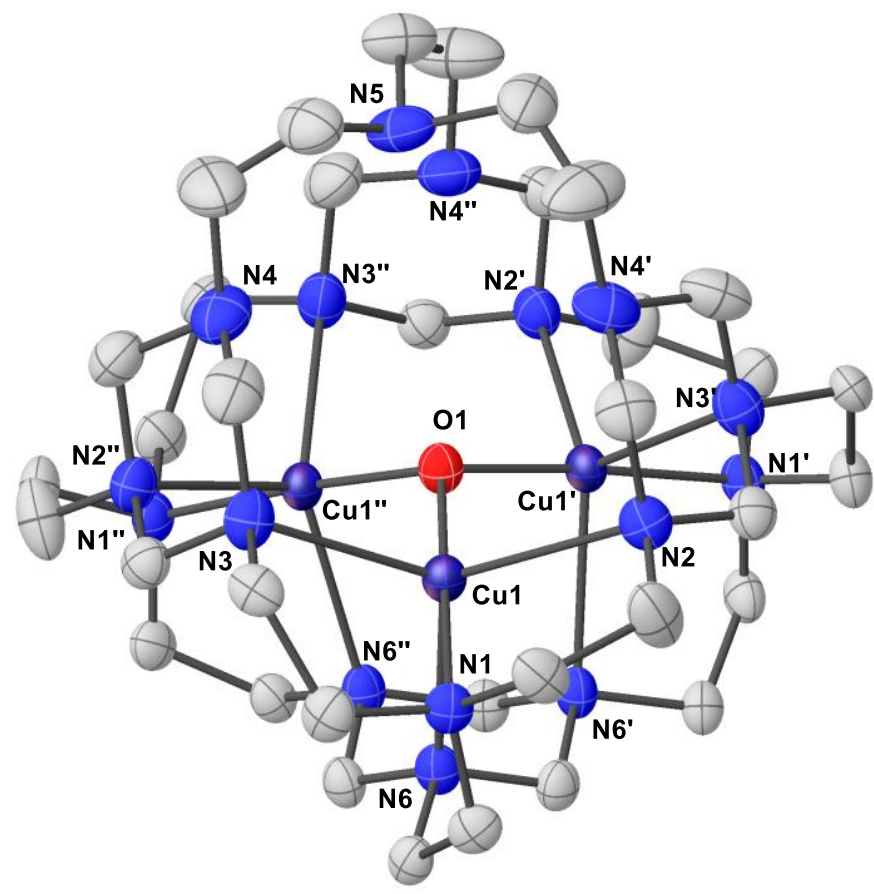

Figure S11: X-ray structure (CIF: 1984893, $100 \mathrm{~K}$ ) of 4a with thermal ellipsoids of $20 \%$ probability. Hydrogen atoms and anion $\mathrm{PF}_{6}{ }^{-}$are omitted for clarity. Selected bond lengths ( $\left.\mathrm{A}\right)$ for 4a: Ave. $\mathrm{Cu}-\mathrm{O}=1.885(5)$, Ave. $\mathrm{Cu} . . \mathrm{Cu}=3.098, \mathrm{Cu}-\mathrm{N}=2.057-2.538$. 


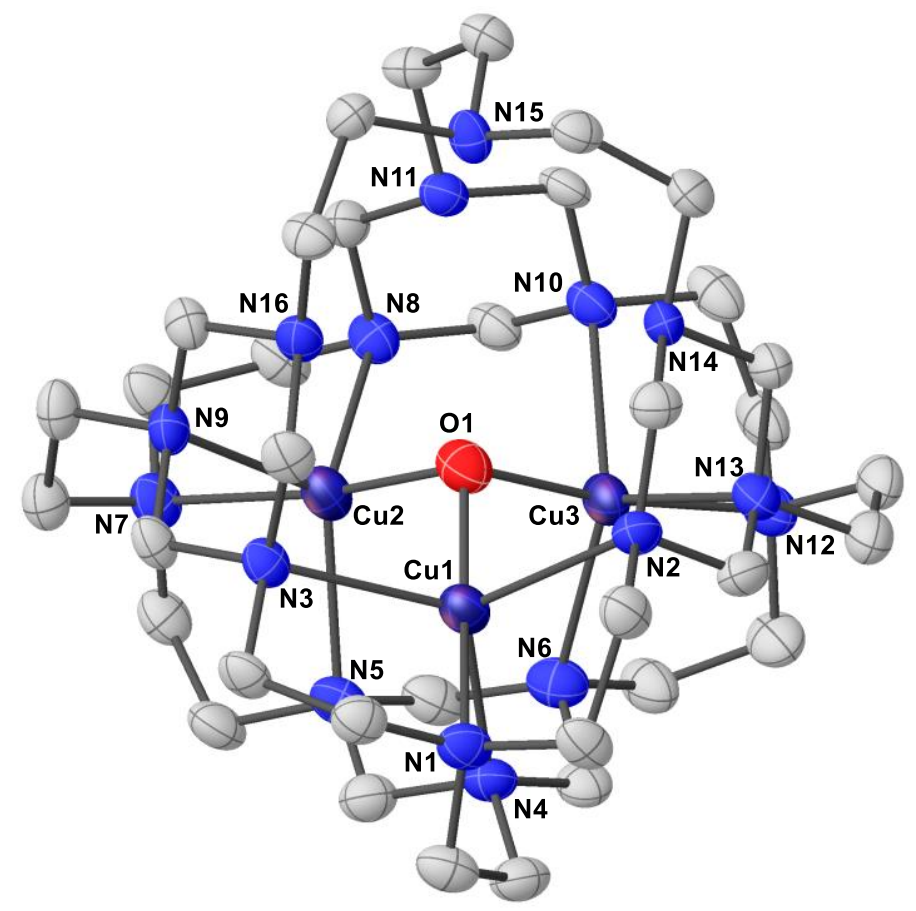

Figure S12: X-ray structure (CIF: 1984894, $100 \mathrm{~K}$ ) of $\mathbf{4 b}$ with thermal ellipsoids of $50 \%$ probability. Hydrogen atoms, solvent molecules, and anion $\mathrm{PF}_{6}{ }^{-}$are omitted for clarity. Selected bond lengths $(\AA)$ for 4 b: Ave. $\mathrm{Cu}-\mathrm{O}=1.913(6)$, Ave. $\mathrm{Cu} \cdots \mathrm{Cu}=3.112, \mathrm{Cu}-\mathrm{N}=$ 2.060-2.491.

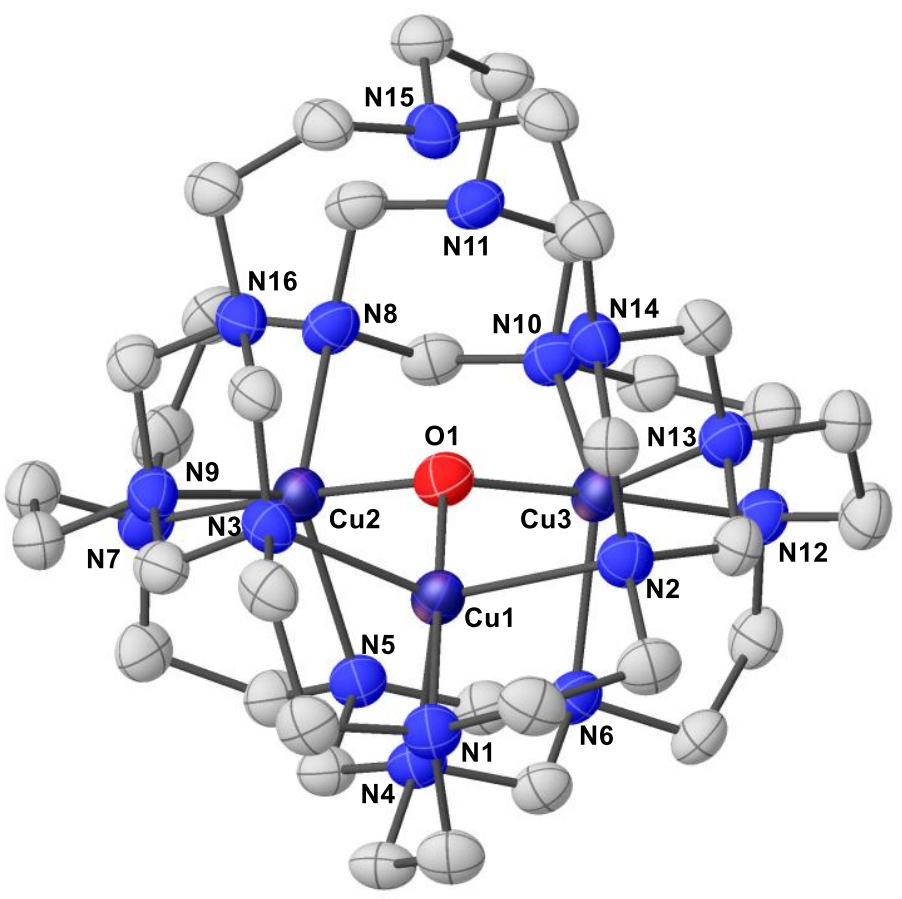

Figure S13: X-ray structure (CIF: 1984895, $100 \mathrm{~K}$ ) of $\mathbf{4 c}$ with thermal ellipsoids of $30 \%$ probability. Hydrogen atoms, solvent molecules, and anion $\mathrm{BF}_{4}{ }^{-} / \mathrm{PF}_{6}{ }^{-}$are omitted for clarity. Selected bond lengths $(\AA)$ for $4 c$ : Ave. $\mathrm{Cu}-\mathrm{O}=1.937(3)$, Ave. $\mathrm{Cu} \cdots \mathrm{Cu}=3.181, \mathrm{Cu}-\mathrm{N}=$ 2.093-2.300. 


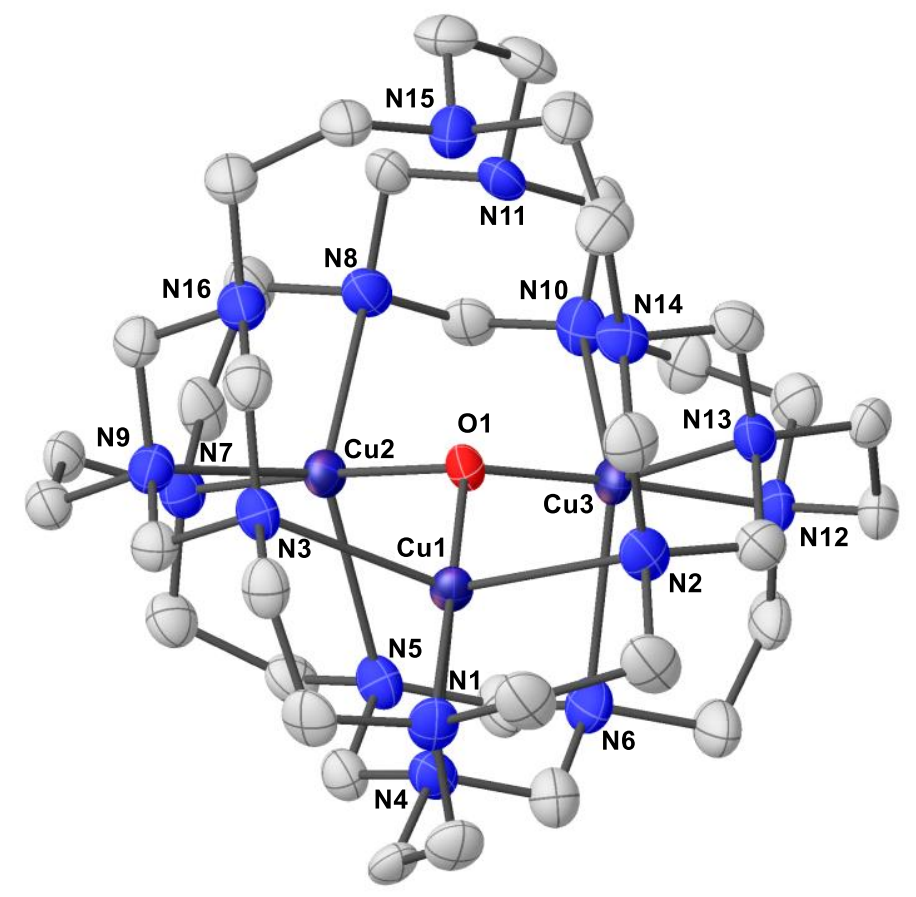

Figure S14: X-ray structure (CIF: 1987932, $100 \mathrm{~K}$ ) of $\mathbf{4 a - B A r}{ }_{4}$ with thermal ellipsoids of $50 \%$ probability. Hydrogen atoms, solvent molecules, and anion $\mathrm{BAr}_{4}^{-}$are omitted for clarity. Selected bond lengths $(\AA)$ for $4 \mathbf{a}-\mathrm{BAr}^{\mathrm{F}}$ : Ave. $\mathrm{Cu}-\mathrm{O}=1.913(2)$, Ave. $\mathrm{Cu} \cdots \mathrm{Cu}=3.129, \mathrm{Cu}-\mathrm{N}$ $=2.049-2.559$.

Table S2: Crystal Data and Structure Refinement for $\mathbf{4 a}, \mathbf{4 b}, \mathbf{4 c}$, and $\mathbf{4 a - B A r}{ }_{4}$.

\begin{tabular}{|c|c|c|c|c|}
\hline & $4 \mathbf{a}$ & $4 b$ & $4 c$ & 4a- $-\mathrm{BAr}_{4}{ }_{4}$ \\
\hline CCDC & 1984893 & 1984894 & 1984895 & 1987932 \\
\hline $\begin{array}{l}\text { Empirical formula, } \\
\text { FW (g/mol) }\end{array}$ & $\begin{array}{l}\mathrm{C}_{36} \mathrm{H}_{73} \mathrm{Cu}_{3} \mathrm{~F}_{12} \mathrm{~N}_{16} \\
\mathrm{OP}_{2}, 1226.64\end{array}$ & $\begin{array}{l}\mathrm{C}_{45} \mathrm{H}_{91} \mathrm{Cu}_{3} \mathrm{~F}_{18} \mathrm{~N}_{16} \\
\mathrm{O}_{4} \mathrm{P}_{3}, 1545.70\end{array}$ & $\begin{array}{l}\mathrm{C}_{39} \mathrm{H}_{79} \mathrm{~B}_{3} \mathrm{Cu}_{3} \mathrm{~F}_{18} \mathrm{~N}_{1} \\
{ }_{6} \mathrm{O}_{2} \mathrm{P}, 1400.20\end{array}$ & $\begin{array}{l}\mathrm{C}_{100} \mathrm{H}_{97} \mathrm{~B}_{2} \mathrm{Cu}_{3} \\
\mathrm{~F}_{48} \mathrm{~N}_{16} \mathrm{O}, 2663.17\end{array}$ \\
\hline Color & Colorless Block & Blue Block & Blue Block & Colorless Block \\
\hline Temperature $(\mathrm{K})$ & 100 & 100 & 100 & 100 \\
\hline Wavelength $(\AA)$ & 1.54178 & 0.71073 & 0.71073 & 0.71073 \\
\hline Crystal system, Space group & Cubic, Pa-3 & $\begin{array}{l}\text { Monoclinic, C } 1 \mathrm{c} \\
1\end{array}$ & $\begin{array}{l}\text { Monoclinic, } \mathrm{C} 1 \\
2 / \mathrm{c} 1\end{array}$ & Triclinic, $\mathrm{P}-1$ \\
\hline Unit cell dimensions a $(\AA)$ & $17.4900(2)$ & $22.6031(11)$ & $35.673(3)$ & $12.4878(13)$ \\
\hline $\mathrm{b}(\AA)$ & $17.4900(2)$ & $17.2489(8)$ & $21.1666(16)$ & 15.1031(17) \\
\hline $\mathrm{c}(\AA)$ & $17.4900(2)$ & $17.6361(8)$ & 21.0194(17) & $15.1131(17)$ \\
\hline$\alpha\left(^{\circ}\right)$ & $90^{\circ}$ & 90 & 90 & $77.567(3)$ \\
\hline$\beta\left(^{\circ}\right)$ & $90^{\circ}$ & $100.981(2)$ & $102.442(2)$ & $88.651(3)$ \\
\hline$\gamma\left({ }^{\circ}\right)$ & $90^{\circ}$ & 90 & 90 & $85.637(3)$ \\
\hline Volume $\left(\AA^{3}\right)$ & $5350.19(18)$ & $6750.0(5)$ & $15498(2)$ & $2775.4(5)$ \\
\hline Z & 4.00008 & 4 & 8 & 1 \\
\hline Density (calc., $\mathrm{g} / \mathrm{cm}^{-3}$ ) & 1.523 & 1.521 & 1.200 & 1.593 \\
\hline $\begin{array}{l}\text { Absorption coefficient } \\
\left(\mathrm{mm}^{-1}\right)\end{array}$ & 2.729 & 1.108 & 0.917 & 0.706 \\
\hline$F(000)$ & 2536 & 3196 & 5760 & 1346 \\
\hline
\end{tabular}




\begin{tabular}{|c|c|c|c|c|}
\hline $\begin{array}{l}\text { Theta range for data collec- } \\
\text { tion }\left({ }^{\circ}\right)\end{array}$ & 6.198 to 68.078 & 2.932 to 25.393 & 1.126 to 25.437 & 3.113 to 25.380 \\
\hline Index ranges & $\begin{array}{l}-20<=\mathrm{h}<=19, \\
-20<=\mathrm{k}<=20, \\
-16<=1<=20\end{array}$ & $\begin{array}{l}-27<=\mathrm{h}<=27, \\
-20<=\mathrm{k}<=20, \\
-20<=\mathrm{l}<=21\end{array}$ & $\begin{array}{l}-42<=\mathrm{h}<=43, \\
-25<=\mathrm{k}<=25, \\
-25<=\mathrm{l}<=24\end{array}$ & $\begin{array}{l}-15<=\mathrm{h}<=15, \\
-18<=\mathrm{k}<=18, \\
-18<=\mathrm{l}<=18\end{array}$ \\
\hline Reflections collected & 33351 & 82474 & 205973 & 111075 \\
\hline Independent reflections, $\mathrm{R}_{\text {int }}$ & $\begin{array}{l}1628 \text { R(int) }= \\
0.0331, \\
\mathrm{R}(\text { sigma })= \\
0.0104]\end{array}$ & $\begin{array}{l}12117 \text { [R(int) }= \\
0.0465, \quad \mathrm{R}(\text { sigma }) \\
=0.0347]\end{array}$ & $\begin{array}{l}14249 \text { [R(int) }= \\
0.0763, \quad \mathrm{R}(\text { sigma }) \\
=0.0452]\end{array}$ & $\begin{array}{l}10153 \quad[\mathrm{R}(\text { int })= \\
0.0801, \quad \mathrm{R}(\text { sigma }) \\
=0.0439]\end{array}$ \\
\hline Completeness to $2 \theta_{\max }(\%)$ & 99.4 & 99.2 & 99.9 & 99.8 \\
\hline Absorption correction & $\begin{array}{l}\text { Semi-empirical } \\
\text { from equivalents }\end{array}$ & $\begin{array}{l}\text { Semi-empirical } \\
\text { from equivalents }\end{array}$ & $\begin{array}{l}\text { Semi-empirical } \\
\text { from equivalents }\end{array}$ & $\begin{array}{l}\text { Semi-empirical } \\
\text { from equivalents }\end{array}$ \\
\hline Refinement method & $\begin{array}{l}\text { Full-matrix } \\
\text { least-squares on } \\
\mathrm{F}^{2}\end{array}$ & $\begin{array}{l}\text { Full-matrix } \\
\text { least-squares on } \\
\mathrm{F}^{2}\end{array}$ & $\begin{array}{l}\text { Full-matrix } \\
\text { least-squares on } \\
\mathrm{F}^{2}\end{array}$ & $\begin{array}{l}\text { Full-matrix } \\
\text { least-squares on } \\
\mathrm{F}^{2}\end{array}$ \\
\hline $\begin{array}{l}\text { Data / restraints / parame- } \\
\text { ters }\end{array}$ & $1628 / 196 / 201$ & 12117 / 194 / 867 & 14249 / 52 / 837 & $\begin{array}{llll}10153 & / & 564 & / \\
1124 & & & \end{array}$ \\
\hline Goodness-of-fit & 1.047 & 1.037 & 1.028 & 1.128 \\
\hline $\begin{array}{l}\text { Final } \mathrm{R} \text { indices } \\
{[\mathrm{I}>2 \operatorname{sigma}(\mathrm{I})]}\end{array}$ & $\begin{array}{l}\mathrm{R} 1=0.0679 \\
\mathrm{wR} 2=0.1844\end{array}$ & $\begin{array}{l}\mathrm{R} 1=0.0530, \mathrm{wR} 2 \\
=0.1221\end{array}$ & $\begin{array}{l}\mathrm{R} 1=0.0616, \mathrm{wR} 2 \\
=0.1770\end{array}$ & $\begin{array}{l}\mathrm{R} 1=0.0791, \mathrm{wR} 2 \\
=0.1663\end{array}$ \\
\hline $\begin{array}{l}\text { Largest diff. peak and hole } \\
\left(e \cdot \AA^{-3}\right)\end{array}$ & $\begin{array}{ll}0.359 & \text { and } \\
-0.218 & \end{array}$ & 0.479 and -0.470 & 0.732 and -0.316 & 0.409 and -0.546 \\
\hline
\end{tabular}

\section{ESI-MS details}

\section{ESI-MS analysis of the reaction of complex $4 a$ and ${ }^{18} \mathrm{O}_{2}$ in the presence of acetic acid}

To an acetone solution $(5 \mathrm{~mL})$ of complex $\mathbf{4 b}(2.2 \mathrm{mg}, 0.0016 \mathrm{mmol})$ in a $20 \mathrm{~mL}$ scintillation vial equipped with a septum, $\mathrm{CoCp}_{2}(0.27 \mathrm{mg}, 0.0015 \mathrm{mmol})$ was added under nitrogen atmosphere to generate complex $4 \mathbf{a}$ in situ. Excess ${ }^{18} \mathrm{O}_{2}(0.5 \mathrm{~mL}, 0.02 \mathrm{mmol})$ and acetic acid ( $2.1 \mathrm{mg}, 0.035 \mathrm{mmol}$ ) was inject to the vial and the obtained mixture was allowed to stir at room temperature for five minutes, during which the color of the solution changed from yellow to blue, indicating complex $4 \mathbf{a}$ was oxidized back to complex $\mathbf{4 b}$. ESI-MS analysis of the resulting blue solution (Figure S15) showed that less than $10 \%$ of $\mu_{3^{-}}{ }^{16} \mathrm{O}$ ligand in $4 \mathbf{a}$ was replaced by ${ }^{18} \mathrm{O}$ during its aerobic oxidation to $\mathbf{4 b}$. 


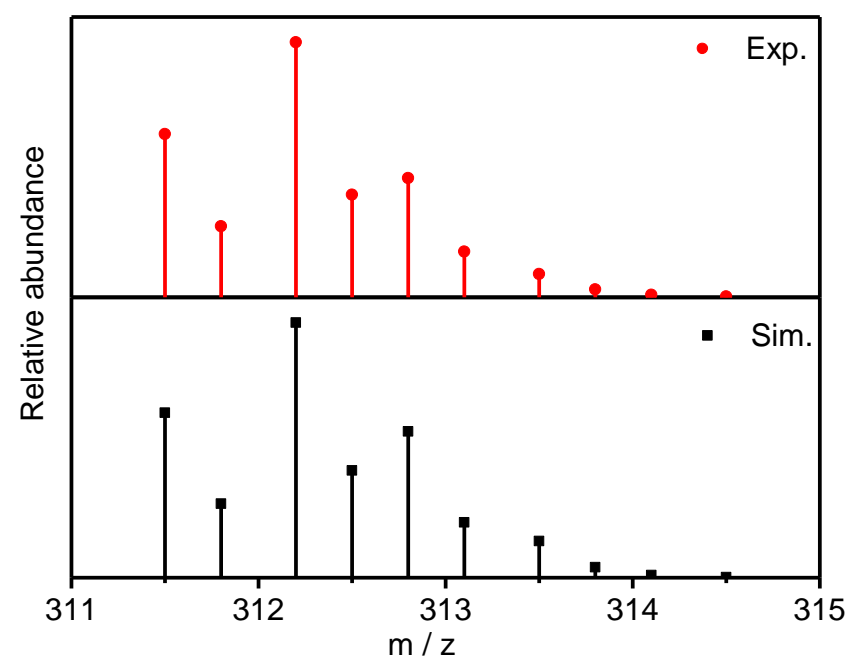

Figure S15. ESI-MS analysis of complex $4 \mathbf{b}$ from the reaction of complex $4 \mathbf{a}$ and ${ }^{18} \mathrm{O}_{2}$ in the presence of acetic acid (red), and simulated mass spectrum with $90 \% \mathbf{4 b}-{ }^{16} \mathrm{O}$ and $10 \% \mathbf{4 b}^{-18} \mathrm{O}$ (black).

\section{X-band EPR details}

EPR spectra were recorded on a Bruker EMXPlus X-band EPR spectrometer equipped with Coldedge cryostat with small-volume power saturation. All samples were measured in $4 \mathrm{~mm}$ septum-capped EPR quartz tubes (Wilmad Lab glass, 727-SQ-250MM). Complex 4b (4.1 mg, $3 \mu \mathrm{mol})$ was dissolved in acetonitrile $(6.0 \mathrm{~mL})$ to make a $0.50 \mathrm{mM}$ solution of $\mathbf{4 b}$, and 0.20 $\mathrm{mL}$ of the solution was transferred into the EPR tube under nitrogen atmosphere, frozen in liquid nitrogen, and used for EPR measurement. The spectrum was collected at $50 \mathrm{~K}$ with a modulation frequency of $100 \mathrm{kHz}$ and a modulation amplitude of $10 \mathrm{G}$ using $30 \mathrm{~dB}$ attenuation. A time constant of $40.96 \mathrm{~ms}$ and a conversion time of $50.15 \mathrm{~ms}$ were used. All spectra were baseline-corrected using Igor Pro (Wavemetrics, Lake Oswego, OR) software. Spectral simulations were performed using the EasySpin toolbox with MATLAB. ${ }^{2}$

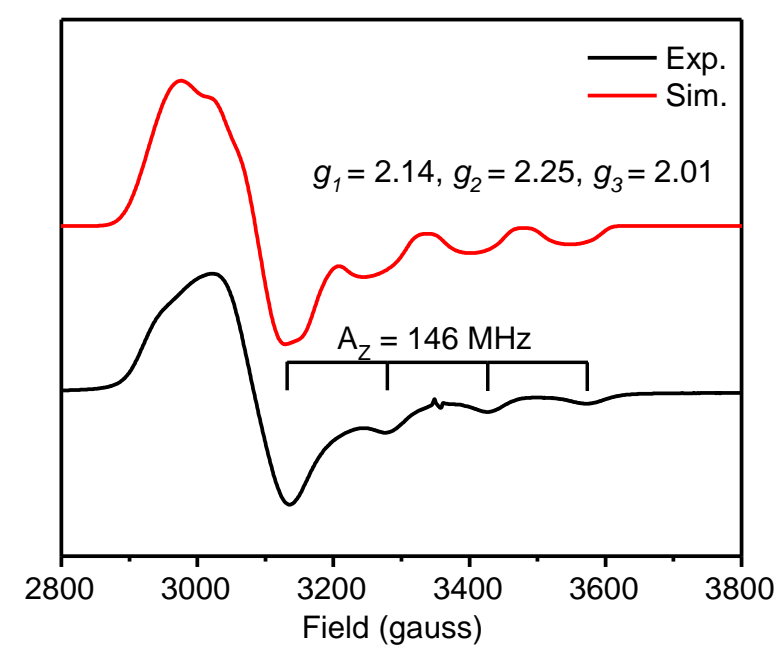

Figure S16. X-band EPR spectrum (frozen MeCN, 50K, $0.5 \mathrm{mM}$ ) of complex 4b; $\mathrm{g}_{1}=2.14$, $\mathrm{g}_{2}=2.25, \mathrm{~g}_{3}=2.01, \mathrm{~A}_{3}=146 \mathrm{MHz}$. 


\section{Electrochemistry details}

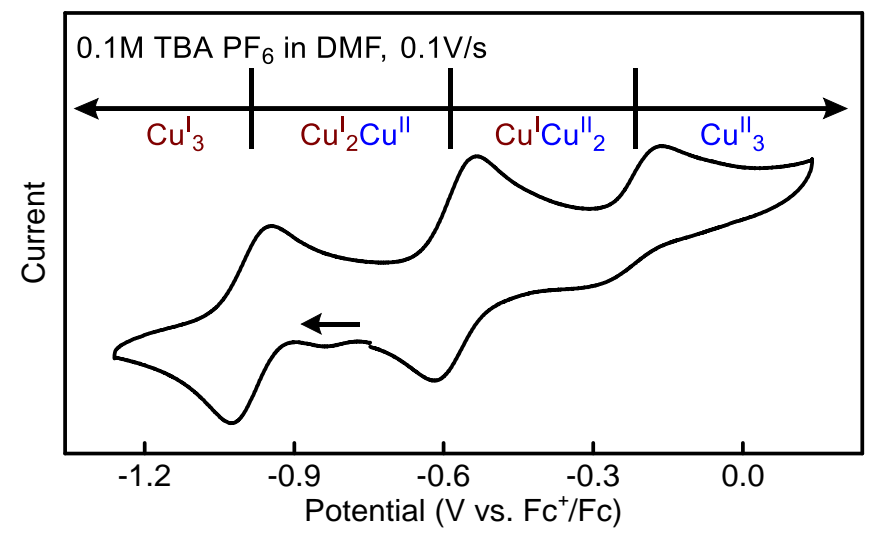

Figure S17. Solution cyclic voltammogram of $\mathbf{4 b}(1 \mathrm{mM})$ in DMF $\left(0.1 \mathrm{M}^{\mathrm{TBAPF}} 6 \mathrm{P}_{6}\right)$ with a scan rate of $0.100 \mathrm{~V} / \mathrm{s}$. Working electrode: glassy carbon; counter electrode: Pt wire; reference electrode: $\mathrm{Ag} / \mathrm{AgNO}_{3}$.

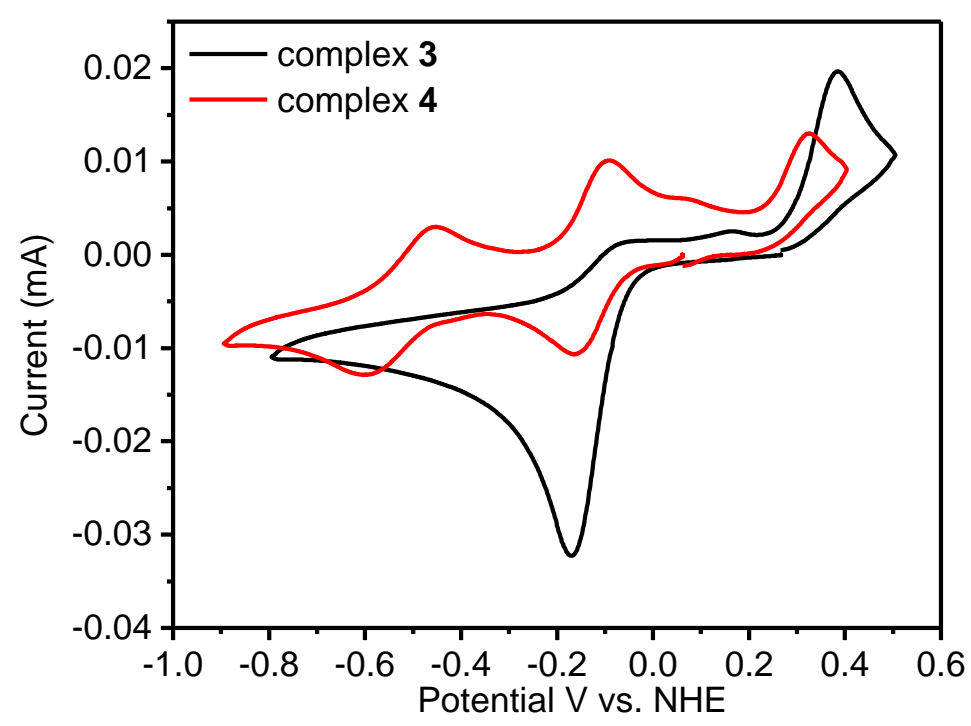

Figure S18. Solution cyclic voltammogram of $4(1 \mathrm{mM})$ and $3(1 \mathrm{mM})$ in phosphate buffer $(\mathrm{pH}=5.8,0.1 \mathrm{M})$ with a scan rate of $0.100 \mathrm{~V} / \mathrm{s}$. Working electrode: glassy carbon; counter electrode: Pt wire; reference electrode: leakless $\mathrm{Ag} / \mathrm{AgCl}$ electrode (eDAQ). 

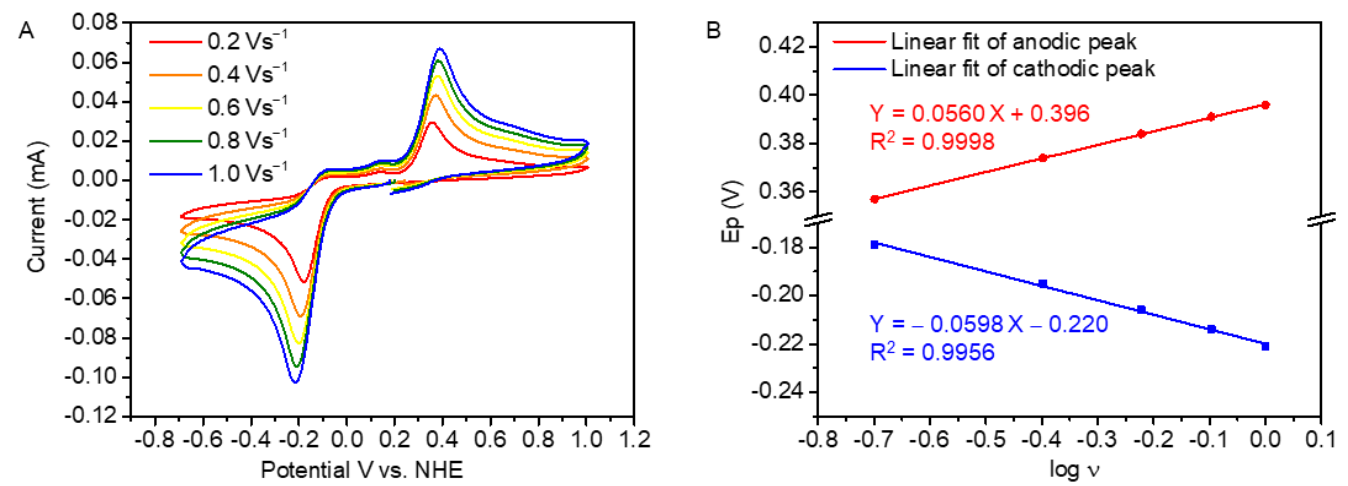

Figure S19. (A) Scan rate dependant cyclic voltammetry of $\mathbf{3 a}(1 \mathrm{mM}, \mathrm{pH}=5.8$ phosphate buffer). (B) Plot of cathodic and anodic potentials against $\log v$ (scan rate, V/s). The number of electrons involved in the redox process can be calculated using Laviron's equation. ${ }^{3}$ The slope obtained from the plot is equal to:

$$
\frac{2.3 \mathrm{RT}}{\alpha \mathrm{Fn}}
$$

where $\alpha$ is the electron-transfer coefficient and assumed to be 0.5 for irreversible process. ${ }^{4} \mathrm{R}$ $\left(8.314 \mathrm{~J} \cdot \mathrm{K}^{-1} \cdot \mathrm{mol}^{-1}\right)$ is the ideal gas constant. T $(298 \mathrm{~K})$ is temperature. $\mathrm{F}\left(96485 \mathrm{C} \cdot \mathrm{mol}^{-1}\right)$ is Faraday constant. $\mathrm{n}$ is the number of electrons involved. $\mathrm{n}_{\mathrm{c}}$, the number of electrons involved in the cathodic process, was calculated to be 2.0. And $\mathrm{n}_{\mathrm{a}}$, the number of electrons involved in the anodic process, was calculated to be 2.1. This result suggests that both the oxidation and the reduction are two-electron processes.

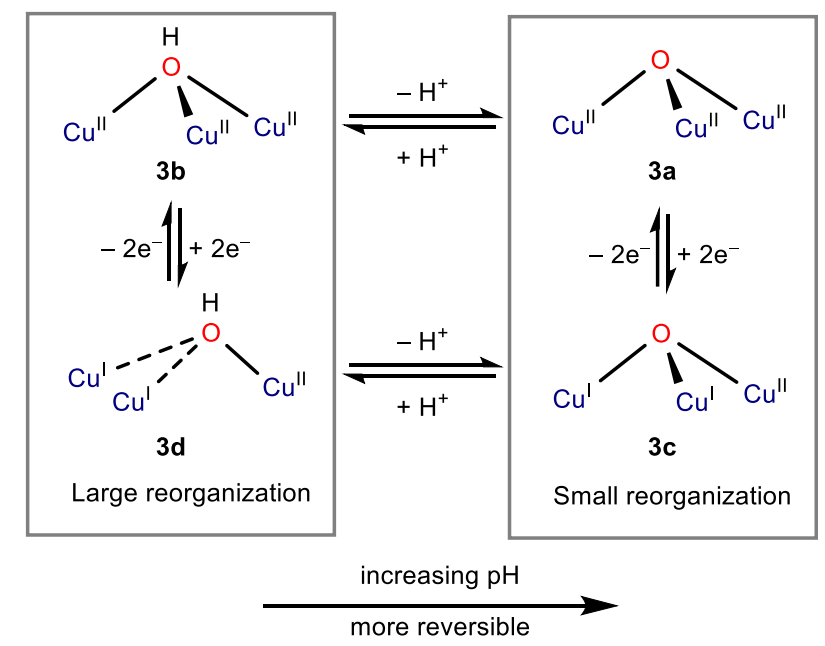

Scheme S2. Proposed redox behavior of 3a based on its $\mathrm{CV}$ at different $\mathrm{pH}$. Under acidic conditions, $\mathbf{3 a}$ is protonated to form $\mathbf{3 b}$ with a $\mu_{3}$-hydroxo ligand. The $c a .800 \mu \mathrm{V}$ separation of the redox couple at low $\mathrm{pH}$ indicates a substantial barrier for electron transfer. Under basic conditions, 3b is deprotonated to afford 3a. The central $\mu_{3}$-oxo ligand in 3a binds to the three copper centers tighter than $\mu_{3}$-hydroxo, attenuating the redox-induced geometric change and lowering the barrier for electron transfer. Consequently, the redox of 3a is more reversible under basic conditions.

Evaluation of the electron self-exchange rate constants $\mathbf{k}_{\mathrm{el}}$ and $\mathbf{k}_{\mathrm{hom}}$.

The standard electrochemical electron self-exchange rate constant $k_{\mathrm{el}}\left(\mathrm{cm} \mathrm{s}^{-1}\right)$ for the $\mathbf{4 a} / \mathbf{4} \mathbf{b}$ 
and $\mathbf{4 b} / \mathbf{4} \mathbf{c}$ redox couples was estimated using an electrochemical method published previously. ${ }^{5}$ Under quasi-reversible conditions, $\mathrm{k}_{\mathrm{el}}$ can be derived from Eq. 1:6,7

$$
\Psi=\mathrm{k}_{\mathrm{el}}\left(\mathrm{D}_{\mathrm{R}} / \mathrm{D}_{\mathrm{O}}\right)^{\alpha / 2}\left(\mathrm{RT} / \mathrm{nF} \pi \mathrm{D}_{\mathrm{R}}\right)^{1 / 2} v^{-1 / 2}
$$

where $\Psi$ is a kinetic parameter, $D_{R}$ and $D_{O}$ are the diffusion coefficients $\left(\mathrm{cm}^{2} / \mathrm{s}\right)$ of the reduced and oxidized species, respectively, $\alpha$ is the transfer coefficient for the electrode process, $\mathrm{R}$ is gas constant (8.314 J K $\left.\mathrm{mol}^{-1}\right)$, $\mathrm{T}$ is temperature $(\mathrm{T}=298.15 \mathrm{~K}$ in this case), $\mathrm{n}$ is the number of electrons transferred in each step $(\mathrm{n}=1$ in this case), $\mathrm{F}$ is Faraday constant $\left(96485.3 \mathrm{C} \mathrm{mol}^{-1}\right)$, and $v$ is the potential scan rate $\left(\mathrm{V} \mathrm{s}^{-1}\right)$. The kinetic parameter $\Psi$ is also related to the peak-to-peak separation $\left(\Delta \mathrm{E}_{\mathrm{p}} / \mathrm{mV}\right)$ of the anodic and cathodic waves in cyclic voltammogram by using the empirical equation (Eq. 2$)^{6}$

$$
\Psi=\left(-0.6288+0.0021 n \Delta E_{p}\right) /\left(1-0.017 n \Delta E_{p}\right)
$$

where $\mathrm{n}$ is the number of electrons transferred in each step. Cyclic voltammograms of $\mathbf{4 a / 4 b}$ and $\mathbf{4 b} / \mathbf{4 c}\left(1 \mathrm{mM}\right.$ in $\left.\mathrm{MeCN}+0.1 \mathrm{M} \mathrm{Bu}_{4} \mathrm{NPF}_{6}\right)$ were measured at different potential scan rates $\left(0.5-5.0 \mathrm{~V} \mathrm{~s}^{-1}\right.$ range) in the suitable potential regions (Figure S20A and S20C). Current interrupt (CI) measurement was performed before the cyclic voltammetry to account for uncompensated resistance $\left(\mathrm{R}_{\mathrm{u}}\right)$. The values of $\Psi$ were calculated from the experimental $\Delta \mathrm{E}_{\mathrm{p}}$ values $(80 \mathrm{mV}-140 \mathrm{mV})$ using the Eq. 2. The value of $D_{O}$ and $D_{R}$ was obtained using the Randles-Sevcik equations $\left(9.4(6) \times 10^{-7} \mathrm{~cm}^{2} \mathrm{~s}^{-1}\right.$ and $9.4(6) \times 10^{-7} \mathrm{~cm}^{2} \mathrm{~s}^{-1}$ for $\mathbf{4 a / 4 b}$ redox couple; $1.5(1) \times 10^{-6} \mathrm{~cm}^{2} \mathrm{~s}^{-1}$ and $1.4(1) \times 10^{-6} \mathrm{~cm}^{2} \mathrm{~s}^{-1}$ for $\mathbf{4 b} / \mathbf{4} \mathbf{c}$ redox couple). Since $\mathrm{D}_{\mathrm{O}} \approx \mathrm{D}_{\mathrm{R}}$ in both redox cases and $0<\alpha<1,\left(\mathrm{D}_{\mathrm{R}} / \mathrm{D}_{\mathrm{O}}\right)^{\alpha / 2}$ is approximated equal to $1 .^{7}$ An estimate of the values of $\mathrm{k}_{\mathrm{el}}$ was obtained from the $\Psi$ vs $v^{-1 / 2}$ plot using Eq. $1\left(7.8(2) \times 10^{-3} \mathrm{~cm} \mathrm{~s}^{-1}\right.$ for $\mathbf{4 a} / \mathbf{4 b}$ redox couple, FigureS19B; 7.6(2) $\times 10^{-3} \mathrm{~cm} \mathrm{~s}^{-1}$ for $\mathbf{4 b} / \mathbf{4} \mathbf{c}$ redox couple, FigureS19D). A correlation between $\mathrm{k}_{\mathrm{el}}$ and the homogeneous electron self-exchange rate constant $\mathrm{k}_{\mathrm{hom}}\left(\mathrm{L} \mathrm{mol}^{-1} \mathrm{~s}^{-1}\right)$ has been described by Weaver et al. (Eq. 3): ${ }^{8}$

$$
\mathrm{k}_{\text {hom }}=4 \pi \mathrm{N}_{\mathrm{A}} \mathrm{r}_{\mathrm{h}}{ }^{2} \mathrm{k}_{\mathrm{el}} 10^{-19}
$$

where $\mathrm{k}_{\mathrm{el}}$ is the electrochemical rate constant $\left(\mathrm{cm} \mathrm{s}^{-1}\right), \mathrm{N}_{\mathrm{A}}$ is the Avogadro constant $\left(\mathrm{mol}^{-1}\right)$, and $r_{h}$ is the internuclear distance for self-exchange $(\AA)$. The value of $r_{h}(11.2 \AA)$ was estimated based on atomic coordinate of the X-ray single-crystal structure $4 \mathbf{b}$ using chemcraft software. The value of $k_{\text {hom }}$ was calculated as $7.4(2) \times 10^{5} \mathrm{~L} \mathrm{~mol}^{-1} \mathrm{~s}^{-1}$ for $4 \mathbf{a} / 4 \mathbf{b}$ redox couple and $7.2(2) \times 10^{5} \mathrm{~L} \mathrm{~mol}^{-1} \mathrm{~s}^{-1}$ for $4 \mathbf{b} / 4 \mathbf{c}$ redox couple. 

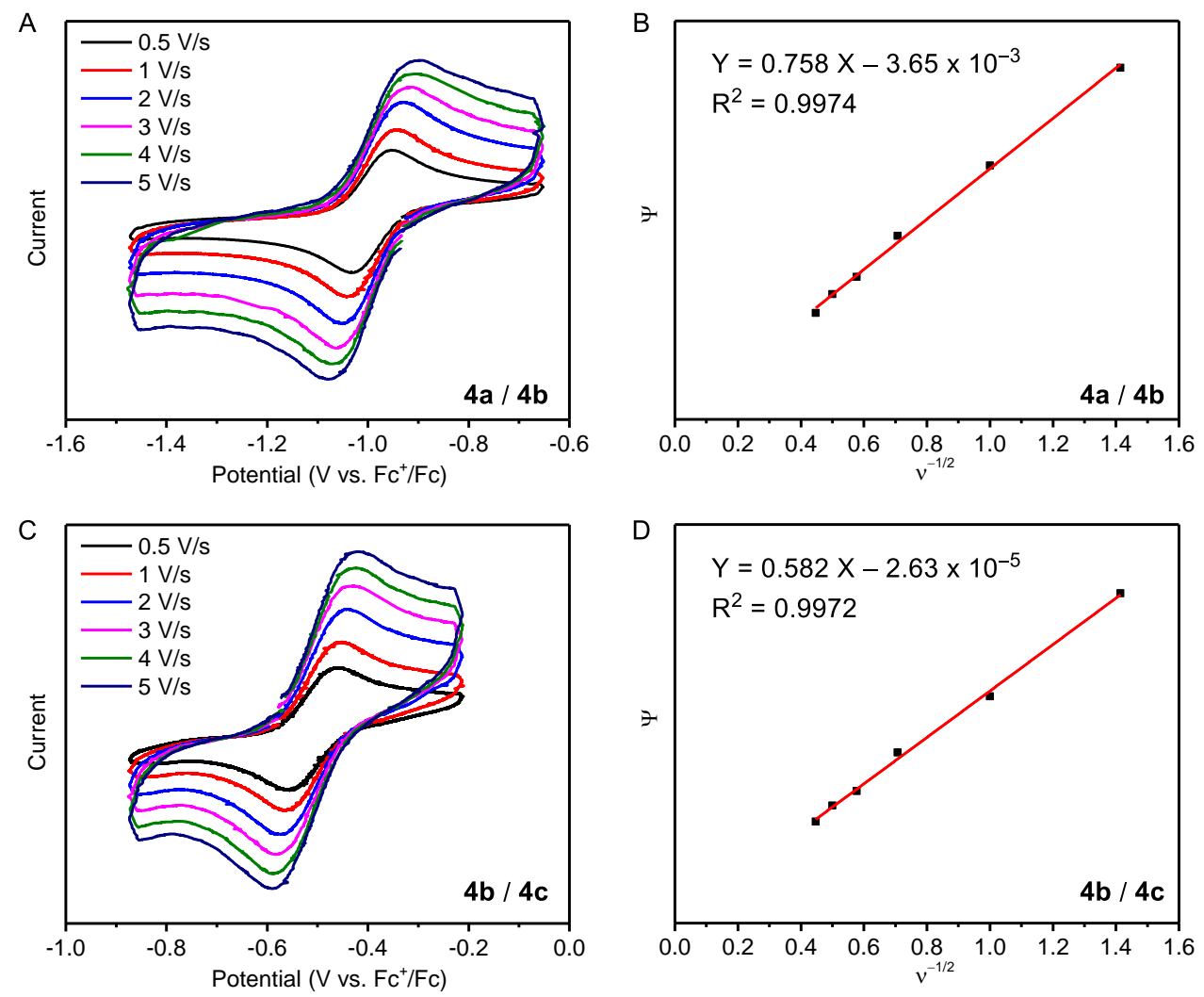

Figure S20. Scan rate dependent cyclic voltammograms for $\mathbf{4 a / 4 b}$ redox couple (A) and $\mathbf{4 b} / \mathbf{4} \mathbf{c}$ redox couple (C). $\Psi$ vs $v^{-1 / 2}$ plots for $\mathbf{4 a} / \mathbf{4 b}$ redox couple (B) and $\mathbf{4 b} / \mathbf{4 c}$ redox couple (D).

\section{Computational details}

All computations were performed using ORCA software packages..$^{9}$ The geometry optimization was carried out using BP86 method with a mixed basis set (def2-TZVP for the copper atoms and def2-SVP for all light atoms, $\mathrm{C}, \mathrm{N}, \mathrm{O}, \mathrm{H}$ ), followed by a frequency calculation. For both complex 3 and 4 in $\mathrm{Cu}^{\mathrm{I}} \mathrm{Cu}^{\mathrm{II}} \mathrm{Cu}^{\mathrm{II}}$ and $\mathrm{Cu}^{\mathrm{II}} \mathrm{Cu}^{\mathrm{II}} \mathrm{Cu}^{\mathrm{II}}$ oxidation states, the structures were optimized at three spin states (singlet, triplet, broken symmetry triplet for $\mathrm{Cu}^{\mathrm{I}} \mathrm{Cu}^{\mathrm{II}} \mathrm{Cu}^{\mathrm{II}}$; doublet, quartet, and broken symmetry quartet for $\mathrm{Cu}^{\mathrm{II}} \mathrm{Cu}^{\mathrm{II}} \mathrm{Cu}^{\mathrm{II}}$ ) at $\mathrm{BP} 86 /$ def2-TZVP $(\mathrm{Cu}) / \mathrm{def} 2-\mathrm{TZVP}(\mathrm{C}, \mathrm{N}, \mathrm{O}, \mathrm{H})$ level of theory to determine the ground state (Table S3). To estimate the reorganization energy $(\lambda)$, single-point calculations of the one-electron oxidized or reduced species at their redox counterpart's geometry were performed. The implication of reorganization energy for the oxidized complex $\left(\lambda_{\mathrm{ox}}\right)$ and the reduced complex $\left(\lambda_{\text {red }}\right)$ of a redox couple is clarified in Figure S21. The total inner-sphere reorganization energy for a self-exchange reaction $\left(\lambda_{\mathrm{i}}\right)$ is the sum of $\lambda_{\text {ox }}$ and $\lambda_{\text {red. }}$ Solvated single-point energies were calculated at TPSSh/def2-TZVP $(\mathrm{Cu}) / \mathrm{def} 2-\mathrm{SVP}(\mathrm{C}, \mathrm{N}, \mathrm{O}, \mathrm{H}) \operatorname{level}^{10}$ with a Solvation Model based on Density (SMD, acetonitrile). ${ }^{11}$ Dispersion corrections with Becke-Johnson damping were applied for single-point calculation. ${ }^{12,13}$ The Gibbs free energy of each species was determined by adding the solvated single point SCF energy to the thermal correction from the respective frequency calculation. ${ }^{14}$ The results are shown in Table S4. Time-dependent density-functional theory (TD-DFT) calculation for complex $\mathbf{4 b}$ and $\mathbf{4 c}$ were performed at BP86/def2-TZVP level using 50 roots. 


\begin{tabular}{|c|c|c|c|}
\hline Oxidation state & Spin state & {$\left[\mathbf{T R E N}_{3} \mathrm{Cu}_{3} \mathrm{O}\right] / \mathrm{Ha}$} & {$\left[\mathbf{T R E N}_{4} \mathrm{Cu}_{3} \mathrm{OH}\right] / \mathrm{Ha}$} \\
\hline \multirow{3}{*}{ I II II } & Singlet & $-6599.04390513^{\mathrm{a}, \mathrm{b}}$ & - \\
\cline { 2 - 4 } & Triplet & $-6599.04831111^{\mathrm{a}, \mathrm{b}}$ & Exp. Ground state \\
\cline { 2 - 4 } & $\begin{array}{c}\text { Triplet } \\
\text { Broken-symmetry }\end{array}$ & $-6599.04390608^{\mathrm{a}, \mathrm{b}}$ & - \\
\hline \multirow{3}{*}{ II II II } & Doublet & $-6598.55474903^{\mathrm{a}, \mathrm{b}}$ & $-7285.19694591^{\mathrm{a}, \mathrm{b}}$ \\
\cline { 2 - 4 } & Quartet & $-6598.55615692^{\mathrm{a}, \mathrm{b}}$ & $-7285.19896527^{\mathrm{a}, \mathrm{b}}$ \\
\cline { 2 - 4 } & $\begin{array}{c}\text { Quartet } \\
\text { Broken-symmetry }\end{array}$ & $-6598.55475856^{\mathrm{a}, \mathrm{b}}$ & $-7285.19535823^{\mathrm{a}, \mathrm{b}}$ \\
\hline
\end{tabular}

a: BP86/SVP; b: SCF single point energy

Table S3: Ground state determination of complex 3 and 4 at the $\mathrm{Cu}^{\mathrm{I}} \mathrm{Cu}^{\mathrm{II}} \mathrm{Cu}^{\mathrm{II}}$ and $\mathrm{Cu}^{\mathrm{II}} \mathrm{Cu}^{\mathrm{II}} \mathrm{Cu}^{\mathrm{II}}$ oxidation states. The isolated $\left[\mathbf{T R E N}_{4} \mathrm{Cu}_{3} \mathrm{OH}\right]$ in $\mathrm{Cu}^{\mathrm{I}} \mathrm{Cu}^{\mathrm{II}} \mathrm{Cu}^{\mathrm{II}}$ oxidation has a paramagnetic ${ }^{1} \mathrm{H}$ NMR, which suggests its triplet ground state.

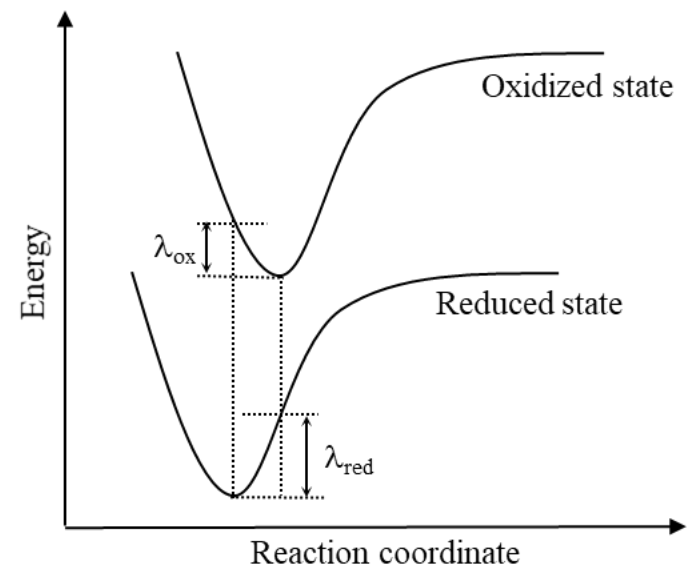

Figure S21. The potential energy of a general electron-transfer process. The reorganization energy of the reduction and the oxidation $\left(\lambda_{\mathrm{ox}}\right.$ and $\left.\lambda_{\text {red }}\right)$ are indicated.

\begin{tabular}{|c|c|c|c|c|}
\hline Complex & Redox couple & $\lambda_{\text {ox }}$ & $\lambda_{\text {red }}$ & $\lambda_{\mathrm{i}}$ \\
\hline \multirow{3}{*}{ Complex 4} & I,I,I - I,I,II & 0.047 & 0.65 & 0.70 \\
\cline { 2 - 5 } & I,I,II - I,II,II & 0.027 & 0.39 & 0.42 \\
\cline { 2 - 5 } & I,II,II - II,II,II & 0.13 & 0.046 & 0.18 \\
\hline \multirow{3}{*}{ Complex 3} & I,I,I - I,I,II & 1.1 & 0.95 & 2.1 \\
\cline { 2 - 5 } & I,I,II - I,II,II & 0.15 & 0.53 & 0.68 \\
\cline { 2 - 5 } & I,II,II - II,II,II & 0.084 & 0.26 & 0.34 \\
\hline
\end{tabular}

Table S4. The calculated $\lambda_{\text {ox }}, \lambda_{\text {red }}$, and $\lambda_{\mathrm{i}}(\mathrm{eV})$ for complex 3 and $\mathbf{4}$. 

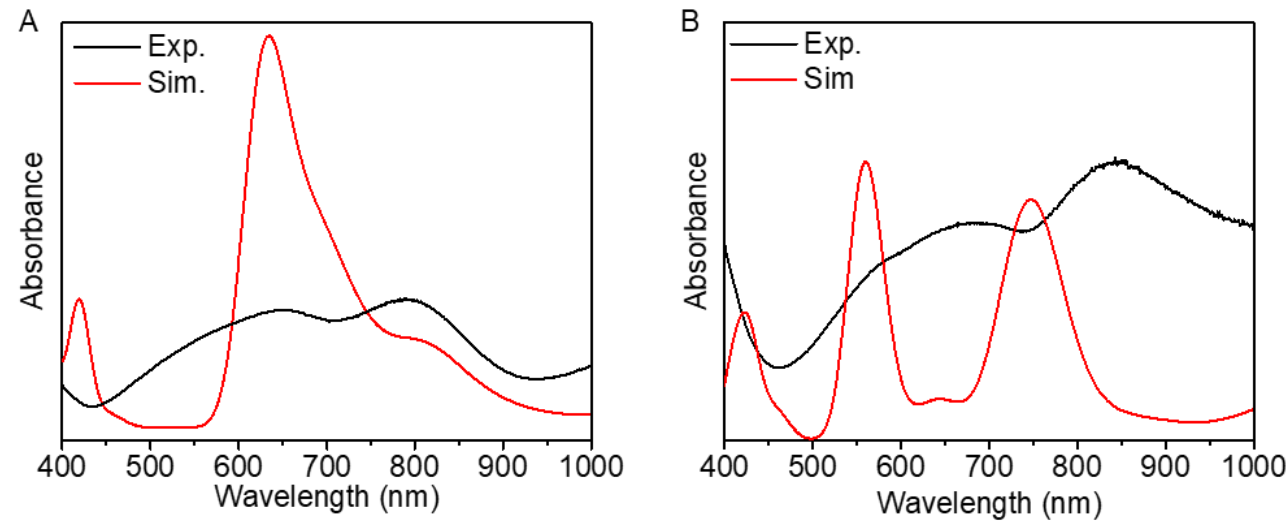

Figure S22. Experimental and simulated UV-vis spectrum of complex $\mathbf{4 b}(\mathrm{A})$ and $\mathbf{4 c}(\mathrm{B})$.

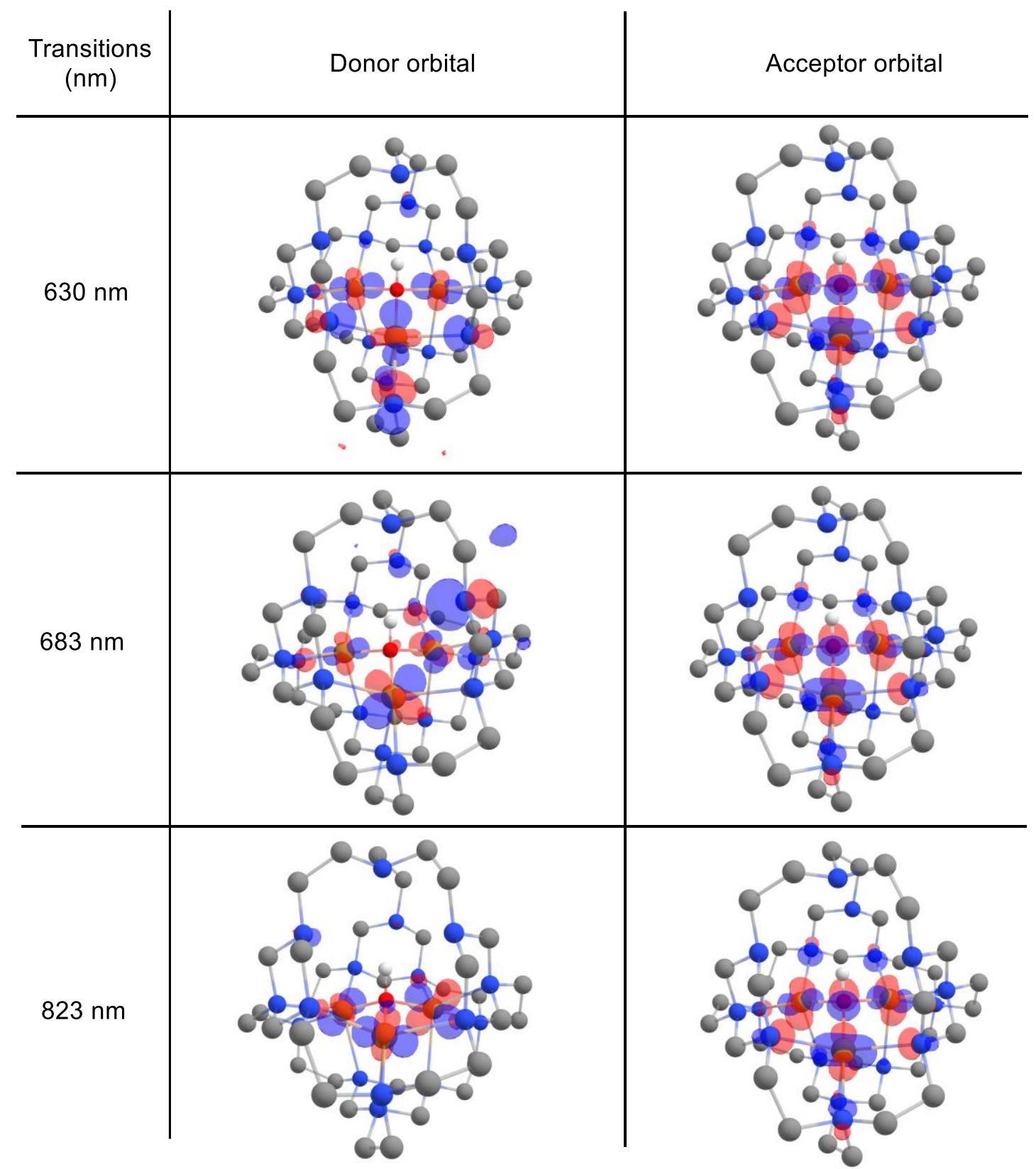

Table S5: Selected TD-DFT transitions for 4b. Orbitals plotted at a 0.048 isosurface value. 


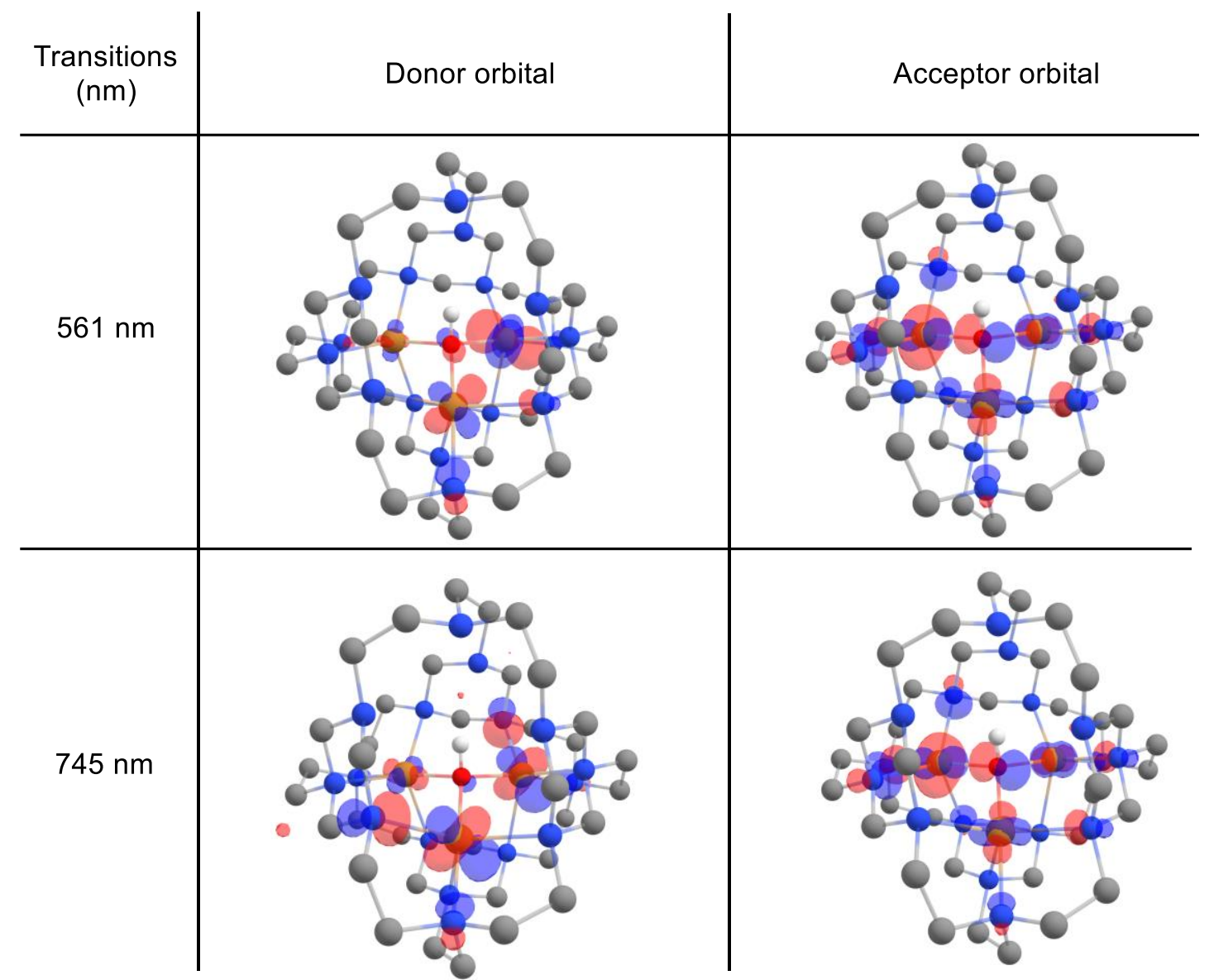

Table S6: Selected TD-DFT transitions for 4c. Orbitals plotted at a 0.048 isosurface value.

\section{Cartesian coordinates of complexes used in computations}

Complex - Level of theory optimized (Calculations used for) Charge, spin multiplicity

[TREN $\left.{ }_{4} \mathrm{Cu}^{\mathrm{I}} \mathrm{Cu}^{\mathrm{I}} \mathrm{Cu}^{\mathrm{I}}\left(\mu_{3}-\mathrm{OH}\right)\right]-\mathrm{BP} 86 / \operatorname{def} 2-\mathrm{SVP}(\mathrm{C}, \mathrm{H}, \mathrm{O}, \mathrm{N}) / \operatorname{def} 2-\mathrm{TZVP}(\mathrm{Cu})$

2,1

29

6

1

1

6

1

1

7

6

1

1

7

7

7

7

6

$1 \quad 11.315256000$

$1 \quad 9.607250000$
$-0.179256000$

2.011531000

2.878547000

1.913309000

$-1.447503000$

$-2.246915000$

$-0.488172000$

$-1.495428000$

$-1.572553000$

$-1.593725000$

$-2.549079000$

$-0.508729000$

$-1.584373000$

$-0.182954000$

$-2.284982000$

0.765416000

0.693894000

0.884495000
10.360415000

12.156563000

12.864461000

11.746150000

12.936769000

13.606288000

13.402451000

11.593444000

12.945956000

14.006910000

12.510799000

12.190831000

9.582177000

7.675744000

7.415317000

12.970879000

13.841371000

13.400234000 


\begin{tabular}{|c|c|c|c|}
\hline 6 & 11.554433000 & -2.725960000 & 8.702771000 \\
\hline 1 & 10.826684000 & -3.402991000 & 9.196248000 \\
\hline 1 & 12.509034000 & -3.313851000 & 8.540103000 \\
\hline 6 & 7.797845000 & -2.849105000 & 11.039747000 \\
\hline 1 & 7.209797000 & -3.545175000 & 11.712482000 \\
\hline 1 & 8.837605000 & -3.232061000 & 10.990502000 \\
\hline 6 & 12.060197000 & -0.937458000 & 11.985616000 \\
\hline 1 & 12.484165000 & -1.318461000 & 12.944471000 \\
\hline 1 & 12.653522000 & -0.038392000 & 11.728707000 \\
\hline 6 & 11.916571000 & -1.311899000 & 6.791432000 \\
\hline 1 & 11.444677000 & -0.951305000 & 5.856688000 \\
\hline 1 & 12.892217000 & -1.815181000 & 6.504521000 \\
\hline 6 & 12.715981000 & -0.648758000 & 8.934966000 \\
\hline 1 & 12.873972000 & 0.226339000 & 9.596813000 \\
\hline 1 & 13.725895000 & -1.145574000 & 8.790588000 \\
\hline 6 & 12.365345000 & 1.643691000 & 5.927806000 \\
\hline 1 & 12.066134000 & 0.948454000 & 5.119042000 \\
\hline 1 & 13.170375000 & 2.282705000 & 5.475675000 \\
\hline 6 & 12.254622000 & -2.006231000 & 10.906266000 \\
\hline 1 & 13.334921000 & -2.299115000 & 10.907353000 \\
\hline 1 & 11.699070000 & -2.927608000 & 11.179993000 \\
\hline 6 & 13.013790000 & 0.840734000 & 7.063088000 \\
\hline 1 & 13.325627000 & 1.529292000 & 7.875897000 \\
\hline 1 & 13.965855000 & 0.403484000 & 6.662554000 \\
\hline 29 & 8.570128000 & -1.616729000 & 7.759195000 \\
\hline 6 & 10.759997000 & -3.415140000 & 6.512144000 \\
\hline 1 & 11.626383000 & -4.123852000 & 6.470437000 \\
\hline 1 & 10.663181000 & -3.004541000 & 5.485846000 \\
\hline 6 & 7.297324000 & -4.191754000 & 9.096962000 \\
\hline 1 & 6.496666000 & -4.860431000 & 9.504539000 \\
\hline 1 & 8.255761000 & -4.658520000 & 9.406361000 \\
\hline 7 & 7.250146000 & -2.848421000 & 9.685257000 \\
\hline 6 & 7.173981000 & -4.200765000 & 7.571885000 \\
\hline 1 & 7.152001000 & -5.261691000 & 7.225534000 \\
\hline 1 & 6.198205000 & -3.764556000 & 7.281421000 \\
\hline 7 & 8.239397000 & -3.446797000 & 6.849592000 \\
\hline 7 & 7.167663000 & -0.837004000 & 5.699587000 \\
\hline 7 & 8.571409000 & 1.068012000 & 5.332419000 \\
\hline 7 & 6.468452000 & 1.330575000 & 6.480667000 \\
\hline 6 & 9.512660000 & -4.228235000 & 6.872456000 \\
\hline 1 & 9.440986000 & -5.098560000 & 6.178108000 \\
\hline 1 & 9.630089000 & -4.657821000 & 7.886400000 \\
\hline 6 & 6.026716000 & 0.043544000 & 5.935708000 \\
\hline 1 & 5.348495000 & -0.449201000 & 6.662854000 \\
\hline 1 & 5.439820000 & 0.206719000 & 4.980574000 \\
\hline 6 & 5.897063000 & -2.293234000 & 9.691639000 \\
\hline 1 & 5.199485000 & -2.965411000 & 10.278559000 \\
\hline 1 & 5.515566000 & -2.243293000 & 8.651368000 \\
\hline 6 & 7.812398000 & -3.241093000 & 5.431568000 \\
\hline 1 & 7.430813000 & -4.199527000 & 5.007176000 \\
\hline 1 & 8.712370000 & -2.985166000 & 4.839186000 \\
\hline 6 & 7.443065000 & 1.953449000 & 5.574906000 \\
\hline 1 & 7.804023000 & 2.887907000 & 6.047085000 \\
\hline 1 & 6.941071000 & 2.240711000 & 4.598702000 \\
\hline 6 & 8.104871000 & -0.190704000 & 4.776215000 \\
\hline
\end{tabular}




\begin{tabular}{|c|c|c|c|}
\hline 1 & 8.979431000 & -0.853455000 & 4.619068000 \\
\hline 1 & 7.609227000 & -0.045760000 & 3.765810000 \\
\hline 6 & 10.400064000 & 2.814039000 & 5.129437000 \\
\hline 1 & 9.705361000 & 3.623515000 & 5.427949000 \\
\hline 1 & 11.040438000 & 3.265569000 & 4.325145000 \\
\hline 6 & 6.744938000 & -2.160632000 & 5.236071000 \\
\hline 1 & 6.453228000 & -2.161334000 & 4.155458000 \\
\hline 1 & 5.822680000 & -2.433456000 & 5.790602000 \\
\hline 6 & 9.596610000 & 1.679672000 & 4.480024000 \\
\hline 1 & 10.284614000 & 0.866169000 & 4.168776000 \\
\hline 1 & 9.160726000 & 2.080752000 & 3.527569000 \\
\hline 29 & 7.133732000 & 0.985916000 & 8.921374000 \\
\hline 8 & 8.864795000 & 0.114946000 & 8.628418000 \\
\hline 6 & 5.338977000 & 2.234920000 & 6.729351000 \\
\hline 1 & 4.631238000 & 2.277421000 & 5.862207000 \\
\hline 1 & 5.750538000 & 3.260785000 & 6.826652000 \\
\hline 6 & 4.555728000 & -0.349247000 & 10.191094000 \\
\hline 1 & 3.885707000 & -0.756137000 & 10.990979000 \\
\hline 1 & 4.089734000 & -0.658122000 & 9.232121000 \\
\hline 7 & 5.898404000 & -0.938916000 & 10.239760000 \\
\hline 6 & 4.548128000 & 1.175837000 & 10.314442000 \\
\hline 1 & 3.487539000 & 1.523286000 & 10.335069000 \\
\hline 1 & 4.983412000 & 1.465885000 & 11.290749000 \\
\hline 7 & 5.304154000 & 1.897357000 & 9.249956000 \\
\hline 7 & 7.914007000 & 3.044624000 & 10.324605000 \\
\hline 7 & 9.820901000 & 3.409892000 & 8.922948000 \\
\hline 7 & 10.080044000 & 2.261255000 & 11.026109000 \\
\hline 6 & 4.524155000 & 1.875382000 & 7.975786000 \\
\hline 1 & 3.654443000 & 2.570607000 & 8.046523000 \\
\hline 1 & 4.093660000 & 0.861886000 & 7.857809000 \\
\hline 6 & 8.793068000 & 2.807526000 & 11.466465000 \\
\hline 1 & 8.298766000 & 2.080822000 & 12.144011000 \\
\hline 1 & 8.956602000 & 3.762412000 & 12.053660000 \\
\hline 6 & 6.452076000 & -0.946087000 & 11.593432000 \\
\hline 1 & 5.778675000 & -1.532507000 & 12.290236000 \\
\hline 1 & 6.502607000 & 0.094087000 & 11.975118000 \\
\hline 7 & 11.190965000 & 2.436277000 & 6.304654000 \\
\hline 6 & 5.510863000 & 3.315137000 & 9.677308000 \\
\hline 1 & 4.552460000 & 3.740484000 & 10.057906000 \\
\hline 1 & 5.768349000 & 3.907361000 & 8.777676000 \\
\hline 6 & 10.704860000 & 3.166496000 & 10.052221000 \\
\hline 1 & 11.639265000 & 2.693447000 & 9.692246000 \\
\hline 1 & 10.992563000 & 4.142349000 & 10.554636000 \\
\hline 6 & 8.562235000 & 3.967362000 & 9.388103000 \\
\hline 1 & 7.900606000 & 4.125176000 & 8.512814000 \\
\hline 1 & 8.707665000 & 4.977604000 & 9.883931000 \\
\hline 6 & 11.569065000 & 3.611045000 & 7.096077000 \\
\hline 1 & 12.377493000 & 3.311640000 & 7.791626000 \\
\hline 1 & 12.022140000 & 4.414918000 & 6.456272000 \\
\hline 6 & 6.590379000 & 3.509413000 & 10.745946000 \\
\hline 1 & 6.590425000 & 4.589988000 & 11.037810000 \\
\hline 1 & 6.316022000 & 2.954997000 & 11.667822000 \\
\hline 6 & 10.434482000 & 4.261588000 & 7.898321000 \\
\hline 1 & 9.622012000 & 4.573522000 & 7.209407000 \\
\hline 1 & 10.836021000 & 5.213710000 & 8.334511000 \\
\hline
\end{tabular}


$\begin{array}{llll}1 & 9.434252000 & 0.683367000 & 8.059623000\end{array}$

[TREN $\left._{4} \mathrm{Cu}^{\mathrm{I}} \mathrm{Cu}^{\mathrm{I}} \mathrm{Cu}^{\mathrm{II}}\left(\mu_{3}-\mathrm{OH}\right)\right]-\mathrm{BP} 86 / \operatorname{def} 2-\mathrm{SVP}(\mathrm{C}, \mathrm{H}, \mathrm{O}, \mathrm{N}) / \operatorname{def} 2-\mathrm{TZVP}(\mathrm{Cu})$

3,2

9.867699000

$-0.252278000$

10.297176000

6

11.003535000

1.970426000

12.057747000

1

11.027273000

2.896362000

12.683653000

12.024885000

1.869689000

11.635057000

8.397633000

7.894433000

8.098392000

7.909043000

$-1.340594000$

12.894941000

$-2.111376000$

13.528052000

$-0.362154000$

13.324360000

$-1.372691000$

11.499656000

9.907769000

10.185168000

$-1.530610000$

13.016478000

$-1.512097000$

14.095906000

10.190401000

$-2.537853000$

12.651056000

10.696260000

$-0.522880000$

12.255915000

11.658692000

$-1.548835000$

9.652030000

12.068763000

10.860800000

10.699457000

$-0.138308000$

7.751116000

$-2.234046000$

7.451121000

0.785005000

12.971991000

11.440417000

0.775505000

13.804403000

9.713253000

0.918153000

13.456622000

11.408508000

$-2.684620000$

8.746904000

10.690042000

$-3.373686000$

9.232315000

12.365953000

$-3.249867000$

8.576365000

7.897300000

7.256819000

$-2.740753000$

10.972296000

$-3.402649000$

11.623795000

$-3.155875000$

10.987740000

12.091369000

$-1.009883000$

12.057090000

12.498026000

12.732425000

$-1.443772000$

12.999191000

$-0.137420000$

11.822924000

$-1.238275000$

6.845599000

11.309599000

$-0.844782000$

5.928537000

12.734381000

$-1.767282000$

6.538872000

$-0.645323000$

8.988749000

12.860459000

13.593307000

12.375517000

0.205856000

9.658056000

$-1.210179000$

8.821449000

1.654369000

5.969708000

0.953654000

5.154203000

2.280823000

5.548643000

13.204196000

$-2.049727000$

10.942542000

$-2.374651000$

10.846843000

13.257632000

$-2.960662000$

11.213506000

12.966919000

0.863844000

7.142286000

1.560859000

7.952600000

0.393563000

6.787675000

13.918938000

$-1.653489000$

7.762670000

$-3.376168000$

6.505207000

10.734697000

$-4.003152000$

6.497111000

$-2.945198000$

5.486202000

10.654784000

7.408799000

$-4.161876000$

9.099819000

$-4.776445000$

9.597903000

8.376452000

$-4.613473000$

9.402750000

7.404152000

9.589209000

$-2.765305000$

7.589235000 


\begin{tabular}{|c|c|c|c|}
\hline 1 & 7.220524000 & -5.346285000 & 7.300868000 \\
\hline 1 & 6.224394000 & -3.880469000 & 7.306773000 \\
\hline 7 & 8.245960000 & -3.517862000 & 6.815302000 \\
\hline 7 & 7.207595000 & -0.861474000 & 5.842430000 \\
\hline 7 & 8.616212000 & 1.027267000 & 5.412652000 \\
\hline 7 & 6.542923000 & 1.340993000 & 6.650146000 \\
\hline 6 & 9.532085000 & -4.272614000 & 6.791161000 \\
\hline 1 & 9.500306000 & -5.087777000 & 6.031746000 \\
\hline 1 & 9.656925000 & -4.779218000 & 7.767849000 \\
\hline 6 & 6.083012000 & 0.035820000 & 6.120847000 \\
\hline 1 & 5.422322000 & -0.448092000 & 6.867709000 \\
\hline 1 & 5.474328000 & 0.209777000 & 5.187999000 \\
\hline 6 & 6.044128000 & -2.207727000 & 9.560324000 \\
\hline 1 & 5.347658000 & -2.870012000 & 10.152354000 \\
\hline 1 & 5.672842000 & -2.187900000 & 8.516808000 \\
\hline 6 & 7.757923000 & -3.271289000 & 5.427238000 \\
\hline 1 & 7.327802000 & -4.204184000 & 4.995779000 \\
\hline 1 & 8.632342000 & -3.020866000 & 4.794885000 \\
\hline 6 & 7.521173000 & 1.935401000 & 5.701109000 \\
\hline 1 & 7.919352000 & 2.861565000 & 6.155790000 \\
\hline 1 & 6.975306000 & 2.227476000 & 4.755882000 \\
\hline 6 & 8.095749000 & -0.211396000 & 4.863525000 \\
\hline 1 & 8.943494000 & -0.884700000 & 4.628726000 \\
\hline 1 & 7.530443000 & -0.040758000 & 3.897952000 \\
\hline 6 & 10.414946000 & 2.787609000 & 5.096288000 \\
\hline 1 & 9.725676000 & 3.616420000 & 5.351278000 \\
\hline 1 & 11.060921000 & 3.194888000 & 4.275908000 \\
\hline 6 & 6.713569000 & -2.157303000 & 5.337840000 \\
\hline 1 & 6.366249000 & -2.087150000 & 4.278590000 \\
\hline 1 & 5.812764000 & -2.430868000 & 5.926270000 \\
\hline 6 & 9.610004000 & 1.626828000 & 4.503998000 \\
\hline 1 & 10.296094000 & 0.810506000 & 4.196426000 \\
\hline 1 & 9.135869000 & 1.989436000 & 3.556522000 \\
\hline 29 & 7.153099000 & 1.134582000 & 8.851469000 \\
\hline 8 & 8.852851000 & 0.142821000 & 8.617909000 \\
\hline 6 & 5.395216000 & 2.279248000 & 6.765410000 \\
\hline 1 & 4.781077000 & 2.285551000 & 5.833364000 \\
\hline 1 & 5.815684000 & 3.301998000 & 6.856736000 \\
\hline 6 & 4.616964000 & -0.351698000 & 10.058400000 \\
\hline 1 & 3.987080000 & -0.862990000 & 10.827099000 \\
\hline 1 & 4.186235000 & -0.645259000 & 9.078350000 \\
\hline 7 & 6.013546000 & -0.838008000 & 10.086433000 \\
\hline 6 & 4.486469000 & 1.155570000 & 10.260945000 \\
\hline 1 & 3.405054000 & 1.424722000 & 10.263047000 \\
\hline 1 & 4.868105000 & 1.433780000 & 11.262714000 \\
\hline 7 & 5.222904000 & 1.957218000 & 9.246379000 \\
\hline 7 & 7.858852000 & 2.892031000 & 10.236735000 \\
\hline 7 & 9.761280000 & 3.354026000 & 8.853719000 \\
\hline 7 & 10.073115000 & 2.108180000 & 10.914385000 \\
\hline 6 & 4.483128000 & 1.977992000 & 7.952198000 \\
\hline 1 & 3.658961000 & 2.727357000 & 7.978183000 \\
\hline 1 & 3.989868000 & 0.996219000 & 7.817485000 \\
\hline 6 & 8.762336000 & 2.598128000 & 11.367512000 \\
\hline 1 & 8.280965000 & 1.827063000 & 12.001725000 \\
\hline 1 & 8.891879000 & 3.526435000 & 11.993690000 \\
\hline
\end{tabular}




$\begin{array}{rrrr}6 & 6.544982000 & -0.831439000 & 11.454951000 \\ 1 & 5.868848000 & -1.424741000 & 12.137154000 \\ 1 & 6.569121000 & 0.208091000 & 11.837911000 \\ 7 & 11.189520000 & 2.451746000 & 6.295688000 \\ 6 & 5.445366000 & 3.344641000 & 9.746261000 \\ 1 & 4.514042000 & 3.754980000 & 10.199241000 \\ 1 & 5.673587000 & 3.992072000 & 8.876993000 \\ 6 & 10.665487000 & 3.064931000 & 9.954255000 \\ 1 & 11.595177000 & 2.616441000 & 9.556937000 \\ 1 & 10.953696000 & 4.013902000 & 10.497746000 \\ 6 & 8.521133000 & 3.894837000 & 9.369944000 \\ 1 & 7.853624000 & 4.152111000 & 8.523929000 \\ 1 & 8.682614000 & 4.840931000 & 9.967295000 \\ 6 & 11.532594000 & 3.651025000 & 7.067082000 \\ 1 & 12.352925000 & 3.392721000 & 7.765211000 \\ 1 & 11.952146000 & 4.464528000 & 6.420426000 \\ 6 & 6.578374000 & 3.420591000 & 10.767405000 \\ 1 & 6.683214000 & 4.474788000 & 11.115915000 \\ 1 & 6.317423000 & 2.830500000 & 11.670706000 \\ 6 & 10.368209000 & 4.256558000 & 7.859115000 \\ 1 & 9.558553000 & 4.562678000 & 7.164755000 \\ 1 & 10.732632000 & 5.204324000 & 8.330877000 \\ 1 & 9.437600000 & 0.695093000 & 8.040209000\end{array}$

\section{$\left[\right.$ TREN $\left._{4} \mathrm{Cu}^{\mathrm{I}} \mathrm{Cu}^{\mathrm{II}} \mathrm{Cu}^{\mathrm{II}}\left(\mu_{3}-\mathrm{OH}\right)\right]-\mathrm{BP} 86 / \mathrm{def} 2-\mathrm{SVP}(\mathrm{C}, \mathrm{H}, \mathrm{O}, \mathrm{N}) / \mathrm{def} 2-\mathrm{TZVP}(\mathrm{Cu})$}

$\begin{array}{lrrr}4,3 & & & \\ 29 & 11.332640000 & 5.553828000 & 4.694543000 \\ 29 & 8.952332000 & 7.914458000 & 4.637590000 \\ 29 & 10.782927000 & 7.404710000 & 7.407496000 \\ 8 & 10.728126000 & 7.341804000 & 5.391253000 \\ 7 & 9.616170000 & 4.313948000 & 5.914762000 \\ 7 & 7.004834000 & 8.315041000 & 3.891774000 \\ 7 & 13.394214000 & 5.563578000 & 5.638601000 \\ 7 & 9.573611000 & 7.906073000 & 2.464139000 \\ 7 & 8.574436000 & 9.821341000 & 5.864378000 \\ 7 & 13.886588000 & 7.900561000 & 6.183297000 \\ 7 & 10.804451000 & 10.644345000 & 5.480747000 \\ 7 & 11.830757000 & 3.593115000 & 4.060469000 \\ 7 & 8.833007000 & 5.877654000 & 7.609103000 \\ 7 & 12.839213000 & 6.498805000 & 7.837149000 \\ 7 & 12.019460000 & 8.043439000 & 2.452275000 \\ 7 & 10.265118000 & 9.597520000 & 7.628435000 \\ 7 & 7.817044000 & 5.871880000 & 5.392870000 \\ 7 & 10.594959000 & 7.343738000 & 9.526794000 \\ 7 & 13.504869000 & 10.147592000 & 4.106372000 \\ 7 & 10.957021000 & 5.878678000 & 2.436908000 \\ 6 & 8.835050000 & 9.819209000 & 7.318437000 \\ 6 & 14.290863000 & 6.735941000 & 5.412774000 \\ 6 & 13.288827000 & 5.305476000 & 7.092956000 \\ 6 & 13.835220000 & 7.575184000 & 7.596097000 \\ 6 & 9.698170000 & 6.508902000 & 1.987735000 \\ 6 & 10.777854000 & 8.682734000 & 2.046360000 \\ 6 & 6.012640000 & 7.400587000 & 4.528065000 \\ 6 & 8.359487000 & 4.518423000 & 5.173840000 \\ 6 & 12.083854000 & 6.696276000 & 1.917933000\end{array}$




\begin{tabular}{|c|c|c|c|}
\hline 6 & 7.590734000 & 6.059726000 & 6.837337000 \\
\hline 6 & 9.355609000 & 4.526975000 & 7.350487000 \\
\hline 6 & 8.503107000 & 6.040485000 & 9.051917000 \\
\hline 6 & 12.071523000 & 3.643784000 & 2.587335000 \\
\hline 6 & 13.201521000 & 8.815396000 & 1.994154000 \\
\hline 6 & 11.093595000 & 10.607811000 & 6.905784000 \\
\hline 6 & 9.394515000 & 10.906608000 & 5.265402000 \\
\hline 6 & 9.728237000 & 6.202649000 & 9.940708000 \\
\hline 6 & 14.804505000 & 9.641065000 & 4.556455000 \\
\hline 6 & 11.029381000 & 4.498088000 & 1.873197000 \\
\hline 6 & 7.122886000 & 10.090878000 & 5.640837000 \\
\hline 6 & 14.025511000 & 4.384434000 & 4.962994000 \\
\hline 6 & 10.096522000 & 2.914800000 & 5.741302000 \\
\hline 6 & 8.387213000 & 8.559616000 & 1.824149000 \\
\hline 6 & 6.687721000 & 9.736890000 & 4.222843000 \\
\hline 6 & 10.713885000 & 2.654776000 & 4.373085000 \\
\hline 6 & 13.070987000 & 3.208299000 & 4.797203000 \\
\hline 6 & 14.803893000 & 9.045918000 & 5.967806000 \\
\hline 6 & 9.999058000 & 8.646347000 & 9.949359000 \\
\hline 6 & 13.380647000 & 10.186747000 & 2.646942000 \\
\hline 6 & 10.500611000 & 9.801858000 & 9.093397000 \\
\hline 6 & 12.783744000 & 6.163184000 & 9.291537000 \\
\hline 6 & 11.616003000 & 11.672958000 & 4.787665000 \\
\hline 6 & 11.972247000 & 7.182603000 & 10.082720000 \\
\hline 6 & 6.526706000 & 5.971951000 & 4.652861000 \\
\hline 6 & 13.124556000 & 11.409593000 & 4.747042000 \\
\hline 6 & 7.058303000 & 8.104733000 & 2.414860000 \\
\hline 1 & 8.506616000 & 10.800415000 & 7.754380000 \\
\hline 1 & 8.227064000 & 9.023886000 & 7.791557000 \\
\hline 1 & 15.343677000 & 6.426068000 & 5.667487000 \\
\hline 1 & 14.261605000 & 6.980916000 & 4.334870000 \\
\hline 1 & 12.574482000 & 4.479076000 & 7.271503000 \\
\hline 1 & 14.287880000 & 4.979723000 & 7.486616000 \\
\hline 1 & 14.833021000 & 7.235759000 & 7.996032000 \\
\hline 1 & 13.551352000 & 8.481469000 & 8.166584000 \\
\hline 1 & 8.845310000 & 5.914583000 & 2.369506000 \\
\hline 1 & 9.653207000 & 6.489019000 & 0.865855000 \\
\hline 1 & 10.738570000 & 8.818177000 & 0.928580000 \\
\hline 1 & 10.712752000 & 9.685019000 & 2.508925000 \\
\hline 1 & 5.757955000 & 7.807589000 & 5.525189000 \\
\hline 1 & 5.060454000 & 7.395728000 & 3.951232000 \\
\hline 1 & 8.543089000 & 4.379793000 & 4.091310000 \\
\hline 1 & 7.602564000 & 3.747940000 & 5.488227000 \\
\hline 1 & 12.046079000 & 6.681882000 & 0.791766000 \\
\hline 1 & 13.044404000 & 6.234675000 & 2.219560000 \\
\hline 1 & 6.804504000 & 5.339345000 & 7.197215000 \\
\hline 1 & 7.209872000 & 7.082919000 & 7.021368000 \\
\hline 1 & 8.626844000 & 3.755145000 & 7.725237000 \\
\hline 1 & 10.303066000 & 4.384040000 & 7.903980000 \\
\hline 1 & 7.845622000 & 6.929030000 & 9.138998000 \\
\hline 1 & 7.898442000 & 5.182251000 & 9.430852000 \\
\hline 1 & 13.086094000 & 4.051268000 & 2.413061000 \\
\hline 1 & 12.074660000 & 2.619338000 & 2.151296000 \\
\hline 1 & 14.092417000 & 8.184021000 & 2.193298000 \\
\hline 1 & 13.181917000 & 8.963118000 & 0.885876000 \\
\hline
\end{tabular}




$\begin{array}{rrrr}1 & 12.156686000 & 10.343830000 & 7.060260000 \\ 1 & 10.917405000 & 11.613405000 & 7.383054000 \\ 1 & 9.198961000 & 10.962388000 & 4.177053000 \\ 1 & 9.067996000 & 11.889146000 & 5.711576000 \\ 1 & 10.339780000 & 5.280190000 & 9.929871000 \\ 1 & 9.395455000 & 6.329360000 & 10.995940000 \\ 1 & 15.161185000 & 8.883082000 & 3.830312000 \\ 1 & 15.591271000 & 10.436886000 & 4.542670000 \\ 1 & 10.022605000 & 4.040016000 & 1.959712000 \\ 1 & 11.258420000 & 4.519021000 & 0.783092000 \\ 1 & 6.552078000 & 9.494770000 & 6.381694000 \\ 1 & 6.872501000 & 11.156352000 & 5.847511000 \\ 1 & 14.388944000 & 4.730429000 & 3.974436000 \\ 1 & 14.930444000 & 4.044831000 & 5.516919000 \\ 1 & 10.841042000 & 2.722993000 & 6.541054000 \\ 1 & 9.275600000 & 2.178762000 & 5.910135000 \\ 1 & 8.511683000 & 9.653926000 & 1.956454000 \\ 1 & 8.379043000 & 8.382026000 & 0.723993000 \\ 1 & 7.195414000 & 10.389454000 & 3.486818000 \\ 1 & 5.598554000 & 9.934933000 & 4.107727000 \\ 1 & 9.947300000 & 2.745598000 & 3.578558000 \\ 1 & 11.066117000 & 1.599279000 & 4.329151000 \\ 1 & 12.777550000 & 2.805487000 & 5.786229000 \\ 1 & 13.598017000 & 2.377566000 & 4.276849000 \\ 1 & 14.518914000 & 9.825346000 & 6.704656000 \\ 1 & 15.858601000 & 8.770031000 & 6.218640000 \\ 1 & 8.896704000 & 8.565593000 & 9.886837000 \\ 1 & 10.226546000 & 8.853989000 & 11.018822000 \\ 1 & 12.528515000 & 10.843787000 & 2.380281000 \\ 1 & 14.268442000 & 10.667286000 & 2.162961000 \\ 1 & 11.592815000 & 9.936321000 & 9.229864000 \\ 1 & 10.029899000 & 10.748472000 & 9.445195000 \\ 1 & 12.339611000 & 5.151680000 & 9.388175000 \\ 1 & 13.805940000 & 6.088720000 & 9.727725000 \\ 1 & 11.217674000 & 11.752276000 & 3.754436000 \\ 1 & 11.461469000 & 12.683710000 & 5.241020000 \\ 1 & 12.470747000 & 8.170875000 & 10.066564000 \\ 1 & 11.931136000 & 6.876909000 & 11.151928000 \\ 1 & 6.685430000 & 5.532871000 & 3.646291000 \\ 1 & 5.735261000 & 5.347644000 & 5.130849000 \\ 1 & 13.537194000 & 11.423297000 & 5.775666000 \\ 1 & 13.593460000 & 12.292298000 & 4.244279000 \\ 1 & 6.888812000 & 7.030500000 & 2.206111000 \\ 1 & 6.227002000 & 8.643700000 & 1.907658000 \\ 1 & 11.389142000 & 8.004095000 & 5.055192000\end{array}$

$\left.\operatorname{TREN}_{4} \mathrm{Cu}^{\mathrm{II}} \mathrm{Cu}^{\mathrm{II}} \mathrm{Cu}^{\mathrm{II}}\left(\mu_{3}-\mathrm{OH}\right)\right]-\mathrm{BP} 86 / \operatorname{def} 2-\mathrm{SVP}(\mathrm{C}, \mathrm{H}, \mathrm{O}, \mathrm{N}) / \operatorname{def} 2-\mathrm{TZVP}(\mathrm{Cu})$

\begin{tabular}{lrrr}
\hline 5,4 & & & \\
29 & 11.301151000 & 5.508161000 & 4.709651000 \\
29 & 8.903489000 & 7.865459000 & 4.645166000 \\
29 & 10.722745000 & 7.370986000 & 7.437181000 \\
8 & 10.694486000 & 7.306051000 & 5.410588000 \\
7 & 9.618399000 & 4.319254000 & 5.887529000 \\
7 & 6.996634000 & 8.310187000 & 3.889444000 \\
7 & 13.377816000 & 5.553089000 & 5.634479000
\end{tabular}




\begin{tabular}{|c|c|c|c|}
\hline 7 & 9.552486000 & 7.893690000 & 2.467821000 \\
\hline f & 8.593633000 & 9.796404000 & 5.842628000 \\
\hline & 13.862294000 & 7.908986000 & 6.131074000 \\
\hline & 10.854487000 & 10.602551000 & 5.492701000 \\
\hline & 11.830244000 & 3.585372000 & 4.063099000 \\
\hline & 8.859758000 & 5.878794000 & 7.614952000 \\
\hline & 12.814083000 & 6.523291000 & 7.822579000 \\
\hline & 12.000379000 & 8.079358000 & 2.489587000 \\
\hline & 10.255405000 & 9.578153000 & 7.643132000 \\
\hline & 7.812549000 & 5.898759000 & 5.399239000 \\
\hline & 10.589229000 & 7.339924000 & 9.535021000 \\
\hline & 13.620621000 & 10.258882000 & 4.061893000 \\
\hline t & 10.970441000 & 5.882876000 & 2.466246000 \\
\hline 6 & 8.832210000 & 9.810266000 & 7.303379000 \\
\hline 6 & 14.276423000 & 6.720493000 & 5.392861000 \\
\hline 6 & 13.272453000 & 5.319934000 & 7.094449000 \\
\hline 6 & 13.794148000 & 7.611253000 & 7.556015000 \\
\hline 6 & 9.707930000 & 6.497074000 & 1.996057000 \\
\hline 6 & 10.747170000 & 8.685337000 & 2.051032000 \\
\hline 6 & 5.993844000 & 7.419421000 & 4.552346000 \\
\hline 6 & 8.351822000 & 4.541503000 & 5.160791000 \\
\hline 6 & 12.096001000 & 6.720507000 & 1.970371000 \\
\hline 6 & 7.607095000 & 6.073630000 & 6.852980000 \\
\hline 6 & 9.371399000 & 4.523443000 & 7.331839000 \\
\hline 6 & 8.521326000 & 6.007407000 & 9.069474000 \\
\hline 6 & 12.098997000 & 3.650799000 & 2.591252000 \\
\hline 6 & 13.168953000 & 8.855754000 & 1.997821000 \\
\hline 6 & 11.097638000 & 10.584347000 & 6.931801000 \\
\hline 6 & 9.442770000 & 10.856371000 & 5.234452000 \\
\hline 6 & 9.745860000 & 6.177306000 & 9.953586000 \\
\hline 6 & 14.861752000 & 9.636736000 & 4.520959000 \\
\hline 6 & 11.065947000 & 4.507318000 & 1.873209000 \\
\hline 6 & 7.144991000 & 10.111131000 & 5.607377000 \\
\hline 6 & 14.019940000 & 4.359063000 & 4.982068000 \\
\hline 6 & 10.072126000 & 2.901686000 & 5.710231000 \\
\hline 6 & 8.357212000 & 8.523320000 & 1.806312000 \\
\hline 6 & 6.706545000 & 9.747078000 & 4.195734000 \\
\hline 6 & 10.701046000 & 2.646225000 & 4.348936000 \\
\hline 6 & 13.059690000 & 3.190254000 & 4.819488000 \\
\hline 6 & 14.820357000 & 9.026721000 & 5.927756000 \\
\hline 6 & 9.967253000 & 8.633301000 & 9.962204000 \\
\hline 6 & 13.369843000 & 10.240853000 & 2.621560000 \\
\hline 6 & 10.463476000 & 9.796155000 & 9.117080000 \\
\hline 6 & 12.797496000 & 6.202098000 & 9.288918000 \\
\hline 6 & 11.654795000 & 11.665491000 & 4.830718000 \\
\hline 6 & 11.977964000 & 7.210170000 & 10.081040000 \\
\hline 6 & 6.495219000 & 5.989398000 & 4.686737000 \\
\hline 6 & 13.171351000 & 11.444951000 & 4.789617000 \\
\hline 6 & 7.037636000 & 8.069668000 & 2.413013000 \\
\hline 1 & 8.508926000 & 10.800196000 & 7.718658000 \\
\hline 1 & 8.205312000 & 9.031985000 & 7.778967000 \\
\hline 1 & 15.324063000 & 6.418063000 & 5.670081000 \\
\hline 1 & 14.267870000 & 6.935830000 & 4.307913000 \\
\hline 1 & 12.566117000 & 4.490464000 & 7.287448000 \\
\hline 1 & 14.272463000 & 5.008625000 & 7.493584000 \\
\hline
\end{tabular}




\begin{tabular}{|c|c|c|c|}
\hline 1 & 14.792968000 & 7.297930000 & 7.969270000 \\
\hline 1 & 13.491015000 & 8.525300000 & 8.103278000 \\
\hline 1 & 8.856022000 & 5.888043000 & 2.355199000 \\
\hline 1 & 9.687398000 & 6.477461000 & 0.874920000 \\
\hline 1 & 10.722124000 & 8.795172000 & 0.931401000 \\
\hline 1 & 10.650298000 & 9.699159000 & 2.483289000 \\
\hline 1 & 5.751346000 & 7.845699000 & 5.544398000 \\
\hline 1 & 5.038547000 & 7.422826000 & 3.980881000 \\
\hline 1 & 8.519672000 & 4.409830000 & 4.075362000 \\
\hline 1 & 7.595161000 & 3.776211000 & 5.479077000 \\
\hline 1 & 12.085309000 & 6.698181000 & 0.845552000 \\
\hline 1 & 13.055827000 & 6.275007000 & 2.295823000 \\
\hline 1 & 6.829393000 & 5.348723000 & 7.214110000 \\
\hline 1 & 7.224807000 & 7.093123000 & 7.051299000 \\
\hline 1 & 8.637174000 & 3.757307000 & 7.699446000 \\
\hline 1 & 10.319427000 & 4.361321000 & 7.878288000 \\
\hline 1 & 7.846732000 & 6.881055000 & 9.169936000 \\
\hline 1 & 7.933085000 & 5.130380000 & 9.426988000 \\
\hline 1 & 13.117751000 & 4.055839000 & 2.436761000 \\
\hline 1 & 12.108880000 & 2.627988000 & 2.151809000 \\
\hline 1 & 14.070634000 & 8.232444000 & 2.166606000 \\
\hline 1 & 13.119539000 & 9.006193000 & 0.891484000 \\
\hline 1 & 12.158634000 & 10.339851000 & 7.127607000 \\
\hline 1 & 10.893751000 & 11.593098000 & 7.386678000 \\
\hline 1 & 9.273697000 & 10.880769000 & 4.140515000 \\
\hline 1 & 9.113031000 & 11.852484000 & 5.641268000 \\
\hline 1 & 10.373369000 & 5.265448000 & 9.939820000 \\
\hline 1 & 9.420168000 & 6.300017000 & 11.011338000 \\
\hline 1 & 15.181275000 & 8.887131000 & 3.771731000 \\
\hline 1 & 15.680225000 & 10.400246000 & 4.529983000 \\
\hline 1 & 10.060435000 & 4.042998000 & 1.929688000 \\
\hline 1 & 11.315294000 & 4.555066000 & 0.789218000 \\
\hline 1 & 6.553782000 & 9.549425000 & 6.358418000 \\
\hline 1 & 6.932536000 & 11.187571000 & 5.795587000 \\
\hline 1 & 14.401587000 & 4.690220000 & 3.995369000 \\
\hline 1 & 14.913651000 & 4.024261000 & 5.555624000 \\
\hline 1 & 10.800654000 & 2.689537000 & 6.519089000 \\
\hline 1 & 9.231874000 & 2.186190000 & 5.863830000 \\
\hline 1 & 8.472834000 & 9.621884000 & 1.905980000 \\
\hline 1 & 8.350827000 & 8.315235000 & 0.712243000 \\
\hline 1 & 7.223312000 & 10.377372000 & 3.447123000 \\
\hline 1 & 5.620611000 & 9.958379000 & 4.074671000 \\
\hline 1 & 9.948116000 & 2.741403000 & 3.542121000 \\
\hline 1 & 11.055734000 & 1.591824000 & 4.301400000 \\
\hline 1 & 12.752499000 & 2.792506000 & 5.806355000 \\
\hline 1 & 13.579453000 & 2.351309000 & 4.305175000 \\
\hline 1 & 14.569007000 & 9.809911000 & 6.671527000 \\
\hline 1 & 15.865850000 & 8.715084000 & 6.172608000 \\
\hline 1 & 8.866719000 & 8.535853000 & 9.894758000 \\
\hline 1 & 10.187271000 & 8.832129000 & 11.034864000 \\
\hline 1 & 12.509626000 & 10.903013000 & 2.404534000 \\
\hline 1 & 14.234751000 & 10.709961000 & 2.087121000 \\
\hline 1 & 11.550175000 & 9.951083000 & 9.270589000 \\
\hline 1 & 9.970050000 & 10.735305000 & 9.455059000 \\
\hline 1 & 12.385645000 & 5.179515000 & 9.407572000 \\
\hline
\end{tabular}




$\begin{array}{rrrr}1 & 13.830363000 & 6.158489000 & 9.702668000 \\ 1 & 11.260870000 & 11.777634000 & 3.799891000 \\ 1 & 11.488434000 & 12.659937000 & 5.313237000 \\ 1 & 12.455598000 & 8.208480000 & 10.060456000 \\ 1 & 11.945307000 & 6.909351000 & 11.151773000 \\ 1 & 6.623884000 & 5.526484000 & 3.687065000 \\ 1 & 5.717458000 & 5.378624000 & 5.200412000 \\ 1 & 13.599856000 & 11.417236000 & 5.809515000 \\ 1 & 13.612769000 & 12.359634000 & 4.319886000 \\ 1 & 6.868105000 & 6.991516000 & 2.226900000 \\ 1 & 6.196751000 & 8.596785000 & 1.909255000 \\ 1 & 11.353151000 & 7.971043000 & 5.077297000\end{array}$

[TREN $\left.{ }_{3} \mathrm{Cu}^{\mathrm{I}} \mathrm{Cu}^{\mathrm{I}} \mathrm{Cu}^{\mathrm{I}}\left(\mu_{3}-\mathrm{O}\right)\right]-\mathrm{BP} 86 / \mathrm{def} 2-\mathrm{SVP}(\mathrm{C}, \mathrm{H}, \mathrm{O}, \mathrm{N}) / \mathrm{def} 2-\mathrm{TZVP}(\mathrm{Cu})$

\begin{tabular}{lrrr}
\hline 1,1 & & & \\
29 & 5.142650000 & 1.378498000 & -2.485868000 \\
7 & 3.599546000 & 0.008147000 & -3.843059000 \\
6 & 3.990698000 & -1.387176000 & -4.160881000 \\
1 & 3.978414000 & -1.951726000 & -3.207063000 \\
1 & 3.219284000 & -1.865609000 & -4.818215000 \\
6 & 5.376240000 & -1.559008000 & -4.822788000 \\
7 & 6.541422000 & -1.138282000 & -4.048112000 \\
7 & 4.964341000 & 2.630356000 & -4.157060000 \\
6 & 6.092672000 & 2.376960000 & -5.090235000 \\
7 & 7.353769000 & 2.666930000 & -4.438305000 \\
29 & 7.828423000 & 1.225693000 & -2.215122000 \\
29 & 6.425283000 & 2.750381000 & -0.553633000 \\
7 & 8.102229000 & 2.913058000 & 1.158071000 \\
6 & 9.397202000 & 2.523003000 & 0.606058000 \\
7 & 9.590117000 & 3.168400000 & -0.690685000 \\
7 & 8.019221000 & -1.650082000 & -2.143339000 \\
6 & 6.992811000 & -2.122506000 & -3.028362000 \\
1 & 7.365468000 & -3.018277000 & -3.577727000 \\
6 & 9.378642000 & -1.464161000 & -2.607531000 \\
1 & 10.038602000 & -1.381079000 & -1.717510000 \\
1 & 9.702238000 & -2.399838000 & -3.117526000 \\
6 & 9.704348000 & -0.330805000 & -3.615446000 \\
7 & 9.615471000 & 1.088967000 & -3.108933000 \\
7 & 3.431167000 & 0.968776000 & -0.963684000 \\
6 & 2.670818000 & -0.161950000 & -1.502907000 \\
6 & 2.382393000 & 0.024713000 & -2.999854000 \\
6 & 3.436626000 & 0.839124000 & -5.048152000 \\
6 & 3.657952000 & 2.337684000 & -4.792640000 \\
6 & 5.024547000 & 4.052453000 & -3.727967000 \\
7 & 6.306979000 & 4.333104000 & -3.109331000 \\
7 & 6.019713000 & 4.703153000 & 0.000640000 \\
6 & 7.288307000 & 5.213551000 & 0.610700000 \\
6 & 7.928909000 & 4.281807000 & 1.653748000 \\
1 & 7.307731000 & 4.248954000 & 2.572124000 \\
1 & 8.898871000 & 4.742375000 & 1.953238000 \\
1 & 8.018073000 & 5.352614000 & -0.209391000 \\
1 & 7.102698000 & 6.210630000 & 1.079788000 \\
6 & 5.589128000 & 5.639778000 & -1.082133000 \\
1 & 4.530763000 & 5.421776000 & -1.315712000 \\
1 & 5.614007000 & 6.687429000 & -0.698321000
\end{tabular}




\begin{tabular}{|c|c|c|c|}
\hline 6 & 6.398842000 & 5.597468000 & -2.387776000 \\
\hline 6 & 7.409534000 & 4.064221000 & -4.018247000 \\
\hline 6 & 8.523139000 & 2.167299000 & -5.156171000 \\
\hline 6 & 9.763411000 & 2.022637000 & -4.266181000 \\
\hline 6 & 10.720835000 & 1.335230000 & -2.118604000 \\
\hline 1 & 11.701259000 & 1.177405000 & -2.631137000 \\
\hline 1 & 10.636943000 & 0.550397000 & -1.342453000 \\
\hline 6 & 10.757520000 & 2.732853000 & -1.449388000 \\
\hline 1 & 10.989795000 & 3.508161000 & -2.211220000 \\
\hline 1 & 11.640614000 & 2.728210000 & -0.773416000 \\
\hline 1 & 10.042187000 & 3.016056000 & -3.865870000 \\
\hline 1 & 10.618544000 & 1.697192000 & -4.904163000 \\
\hline 1 & 8.245291000 & 1.181218000 & -5.580434000 \\
\hline 1 & 8.810377000 & 2.814214000 & -6.024716000 \\
\hline 1 & 7.387733000 & 4.748832000 & -4.921638000 \\
\hline 1 & 8.361956000 & 4.255848000 & -3.484554000 \\
\hline 1 & 7.473168000 & 5.781890000 & -2.181307000 \\
\hline 1 & 6.057572000 & 6.471722000 & -3.002010000 \\
\hline 6 & 4.948621000 & 4.583566000 & 1.049449000 \\
\hline 6 & 3.520463000 & 4.291071000 & 0.527384000 \\
\hline 7 & 3.443022000 & 3.315145000 & -0.551065000 \\
\hline 6 & 2.673733000 & 2.083071000 & -0.389903000 \\
\hline 1 & 1.697903000 & 2.137872000 & -0.927489000 \\
\hline 1 & 3.041779000 & 5.253365000 & 0.227229000 \\
\hline 1 & 2.934171000 & 3.946168000 & 1.410304000 \\
\hline 1 & 5.268681000 & 3.773304000 & 1.735068000 \\
\hline 1 & 4.903468000 & 5.527165000 & 1.646469000 \\
\hline 1 & 4.845230000 & 4.715310000 & -4.626387000 \\
\hline 1 & 4.206825000 & 4.217132000 & -2.998028000 \\
\hline 1 & 2.876471000 & 2.733702000 & -4.111734000 \\
\hline 1 & 3.548452000 & 2.883444000 & -5.761841000 \\
\hline 1 & 4.156277000 & 0.487475000 & -5.812418000 \\
\hline 1 & 2.427052000 & 0.714672000 & -5.513324000 \\
\hline 1 & 1.877988000 & 1.004620000 & -3.130216000 \\
\hline 1 & 1.653247000 & -0.750199000 & -3.345697000 \\
\hline 1 & 3.266505000 & -1.084458000 & -1.347266000 \\
\hline 1 & 1.705036000 & -0.325737000 & -0.970150000 \\
\hline 1 & 8.996217000 & -0.425977000 & -4.460843000 \\
\hline 1 & 10.739428000 & -0.490171000 & -4.006190000 \\
\hline 1 & 9.378883000 & 1.405135000 & 0.559092000 \\
\hline 1 & 5.942230000 & 3.005764000 & -6.017285000 \\
\hline 1 & 6.088833000 & 1.313699000 & -5.390434000 \\
\hline 1 & 5.381959000 & -1.047005000 & -5.812345000 \\
\hline 1 & 5.484248000 & -2.637526000 & -5.071007000 \\
\hline 1 & 6.145900000 & -2.475116000 & -2.387543000 \\
\hline 1 & 2.421810000 & 1.915663000 & 0.692100000 \\
\hline 1 & 10.254150000 & 2.816707000 & 1.264903000 \\
\hline 1 & 6.313646000 & -0.256422000 & -3.539311000 \\
\hline 1 & 7.681873000 & -0.940863000 & -1.473599000 \\
\hline 1 & 7.801250000 & 2.218795000 & 1.847391000 \\
\hline 1 & 4.387904000 & 3.047541000 & -0.904278000 \\
\hline 1 & 4.187634000 & 0.661089000 & -0.335684000 \\
\hline 1 & 8.721686000 & 2.981075000 & -1.242204000 \\
\hline 8 & 6.405816000 & 0.936532000 & -1.057821000 \\
\hline
\end{tabular}


TRREN $\left._{3} \mathrm{Cu}^{\mathrm{I}} \mathrm{Cu}^{\mathrm{I}} \mathrm{Cu}^{\mathrm{II}}\left(\mu_{3}-\mathrm{O}\right)\right]-\mathrm{BP} 86 /$ def2-SVP $(\mathrm{C}, \mathrm{H}, \mathrm{O}, \mathrm{N}) / \operatorname{def} 2-\mathrm{TZVP}(\mathrm{Cu})$

2,2 29 7

6

1

1

6

7

7

6

7

29

29

7

6

7

7

6

1

6

1

1

6

7

7

6

6

6

6

6

7
5.113601000

3.416344000

3.495152000

3.120133000

2.816326000

4.909727000

5.832736000

5.108129000

6.257924000

7.510572000

8.041408000

6.197588000

7.960702000

9.332713000

9.685306000

8.177109000

7.221777000

7.423134000

9.579668000

10.195712000

9.715593000

10.077503000

9.966616000

3.247547000

2.182785000

2.141107000

3.499469000

3.823667000

5.167724000

6.412325000

5.837123000

7.049690000

7.613920000

6.869512000

8.488825000

7.816652000

6.836477000

5.589354000

4.531337000

5.690881000

6.506316000

7.564875000

8.665976000

9.981924000

11.097106000

12.049648000

11.229850000

10.893408000

10.790457000

11.827555000

10.242536000

10.795971000

8.426684000
$0.579796000 \quad-2.423412000$

$0.075222000 \quad-3.714160000$

$-1.378380000 \quad-4.024000000$

$-1.935554000 \quad-3.142043000$

$-1.641528000 \quad-4.869412000$

$-1.851175000 \quad-4.339291000$

$-1.508324000 \quad-3.244264000$

$2.608988000 \quad-4.112997000$

$2.349894000 \quad-4.977066000$

$2.550797000 \quad-4.246704000$

$0.982797000 \quad-2.282325000$

$2.922971000 \quad-0.652406000$

$3.116538000 \quad 0.816342000$

$3.219660000 \quad 0.287810000$

$2.091716000 \quad-0.551806000$

$-1.228943000 \quad-2.634919000$

$-1.808268000 \quad-3.587275000$

$-1.369017000 \quad-4.586354000$

$-1.467009000 \quad-3.031345000$

$-1.518237000 \quad-2.112721000$

$-2.445852000 \quad-3.547367000$

$-0.346307000 \quad-3.949980000$

$0.993277000 \quad-3.312555000$

$0.661011000 \quad-0.804892000$

$-0.053394000 \quad-1.518208000$

$0.349639000 \quad-2.998236000$

$0.867374000 \quad-4.971369000$

$2.352022000 \quad-4.775912000$

$3.974925000 \quad-3.598192000$

$4.201743000 \quad-2.857734000$

$4.983253000 \quad 0.037104000$

$5.410806000 \quad 0.783833000$

$4.280532000 \quad 1.651187000$

$3.961764000 \quad 2.407415000$

$4.668101000 \quad 2.224485000$

$5.722979000 \quad 0.048223000$

$6.307252000 \quad 1.411893000$

$5.854755000 \quad-1.140211000$

$5.723427000-1.444106000$

$6.931529000-0.863213000$

$5.574413000 \quad-2.334178000$

$3.914160000 \quad-3.715853000$

$2.242506000 \quad-5.101902000$

$2.069900000 \quad-4.337590000$

$1.177532000 \quad-2.358460000$

$1.348278000 \quad-2.913336000$

$0.227371000 \quad-1.802579000$

$2.303608000 \quad-1.347499000$

$3.279942000 \quad-1.869720000$

$2.388276000 \quad-0.739229000$

$3.017880000 \quad-3.827836000$

$1.894090000 \quad-5.080196000$

$1.311063000 \quad-5.657815000$ 


$\begin{array}{rrrr}1 & 8.829908000 & 3.025997000 & -5.885052000 \\ 1 & 7.619776000 & 4.659223000 & -4.567470000 \\ 1 & 8.482997000 & 4.032831000 & -3.107042000 \\ 1 & 7.564608000 & 5.742334000 & -2.042938000 \\ 1 & 6.285718000 & 6.337727000 & -3.122611000 \\ 6 & 4.666726000 & 5.005429000 & 0.955084000 \\ 6 & 3.500727000 & 4.151708000 & 0.474930000 \\ 7 & 3.916938000 & 2.763691000 & 0.228313000 \\ 6 & 2.831496000 & 1.993803000 & -0.382548000 \\ 1 & 2.504994000 & 2.554544000 & -1.284050000 \\ 1 & 3.091050000 & 4.551674000 & -0.476791000 \\ 1 & 2.671396000 & 4.237765000 & 1.217762000 \\ 1 & 4.999807000 & 4.627422000 & 1.941980000 \\ 1 & 4.319338000 & 6.050867000 & 1.126593000 \\ 1 & 5.073846000 & 4.727580000 & -4.439807000 \\ 1 & 4.305885000 & 4.127217000 & -2.918109000 \\ 1 & 3.034614000 & 2.828322000 & -4.157974000 \\ 1 & 3.760639000 & 2.847610000 & -5.777948000 \\ 1 & 4.270325000 & 0.401324000 & -5.617324000 \\ 1 & 2.542922000 & 0.791906000 & -5.541001000 \\ 1 & 1.932577000 & 1.435111000 & -3.072406000 \\ 1 & 1.289200000 & -0.164334000 & -3.502281000 \\ 1 & 2.364921000 & -1.142484000 & -1.416782000 \\ 1 & 1.169362000 & 0.125532000 & -1.082040000 \\ 1 & 9.470602000 & -0.337442000 & -4.876211000 \\ 1 & 11.126403000 & -0.552993000 & -4.266366000 \\ 1 & 10.057667000 & 3.375725000 & 1.134176000 \\ 1 & 6.221299000 & 3.014399000 & -5.893976000 \\ 1 & 6.226661000 & 1.299093000 & -5.327240000 \\ 1 & 5.287698000 & -1.362486000 & -5.261776000 \\ 1 & 4.878045000 & -2.943684000 & -4.561083000 \\ 1 & 7.385530000 & -2.913843000 & -3.686546000 \\ 1 & 1.933267000 & 1.948144000 & 0.295040000 \\ 1 & 9.392372000 & 4.135648000 & -0.338268000 \\ 1 & 5.570300000 & -2.048211000 & -2.405646000 \\ 1 & 8.005272000 & -1.619660000 & -1.699077000 \\ 1 & 7.877202000 & 2.250259000 & 1.363614000 \\ 1 & 4.173965000 & 2.325360000 & 1.125457000 \\ 1 & 3.568837000 & 0.114865000 & 0.003371000 \\ 1 & 9.789111000 & 1.242538000 & 0.020631000 \\ 8 & 6.474696000 & 1.163979000 & -1.251286000\end{array}$

[TREN $\left.{ }_{3} \mathrm{Cu}^{\mathrm{I}} \mathrm{Cu}^{\mathrm{II}} \mathrm{Cu}^{\mathrm{II}}\left(\mu_{3}-\mathrm{O}\right)\right]-\mathrm{BP} 86 / \operatorname{def} 2-\mathrm{SVP}(\mathrm{C}, \mathrm{H}, \mathrm{O}, \mathrm{N}) / \operatorname{def} 2-\mathrm{TZVP}(\mathrm{Cu})$

$\begin{array}{lrrr}3,3 & & & \\ 29 & 5.013514000 & 0.642931000 & -2.445526000 \\ 7 & 3.370342000 & 0.079773000 & -3.764293000 \\ 6 & 3.501299000 & -1.367388000 & -4.095789000 \\ 1 & 3.095849000 & -1.957383000 & -3.249704000 \\ 1 & 2.879667000 & -1.632801000 & -4.981157000 \\ 6 & 4.947675000 & -1.768680000 & -4.339857000 \\ 7 & 5.804839000 & -1.386192000 & -3.189495000 \\ 7 & 5.091639000 & 2.552374000 & -4.021035000 \\ 6 & 6.245253000 & 2.285569000 & -4.893939000 \\ 7 & 7.515811000 & 2.492293000 & -4.178846000 \\ 29 & 8.129092000 & 1.094591000 & -2.239055000\end{array}$




\begin{tabular}{|c|c|c|c|}
\hline 29 & 6.158894000 & 2.985397000 & -0.669338000 \\
\hline 7 & 7.848373000 & 3.055874000 & 0.768780000 \\
\hline 6 & 9.206555000 & 3.135575000 & 0.207034000 \\
\hline 7 & 9.548084000 & 2.012951000 & -0.674142000 \\
\hline 7 & 8.163024000 & -1.107790000 & -2.530103000 \\
\hline 6 & 7.210131000 & -1.677776000 & -3.496651000 \\
\hline 1 & 7.431122000 & -1.242985000 & -4.492029000 \\
\hline 6 & 9.559760000 & -1.424091000 & -2.932943000 \\
\hline 1 & 10.184184000 & -1.449687000 & -2.018900000 \\
\hline 1 & 9.641192000 & -2.436850000 & -3.387548000 \\
\hline 6 & 10.080029000 & -0.379666000 & -3.922754000 \\
\hline 7 & 10.003054000 & 0.991123000 & -3.346917000 \\
\hline 7 & 3.412823000 & 0.649856000 & -0.913602000 \\
\hline 6 & 2.279685000 & -0.092213000 & -1.531313000 \\
\hline 6 & 2.114014000 & 0.311263000 & -2.998331000 \\
\hline 6 & 3.435506000 & 0.910444000 & -4.998465000 \\
\hline 6 & 3.804537000 & 2.370954000 & -4.735709000 \\
\hline 6 & 5.174391000 & 3.936186000 & -3.527525000 \\
\hline 7 & 6.427832000 & 4.168431000 & -2.793195000 \\
\hline 7 & 5.841734000 & 5.025905000 & 0.038130000 \\
\hline 6 & 7.058573000 & 5.406559000 & 0.807650000 \\
\hline 6 & 7.572982000 & 4.230229000 & 1.640124000 \\
\hline 1 & 6.824026000 & 3.926360000 & 2.397048000 \\
\hline 1 & 8.475426000 & 4.545806000 & 2.210111000 \\
\hline 1 & 7.838222000 & 5.732491000 & 0.091252000 \\
\hline 1 & 6.859899000 & 6.282835000 & 1.465305000 \\
\hline 6 & 5.624528000 & 5.905070000 & -1.142721000 \\
\hline 1 & 4.561784000 & 5.813446000 & -1.445503000 \\
\hline 1 & 5.767582000 & 6.977212000 & -0.872694000 \\
\hline 6 & 6.534230000 & 5.573267000 & -2.325734000 \\
\hline 6 & 7.567537000 & 3.874199000 & -3.679061000 \\
\hline 6 & 8.642661000 & 2.200630000 & -5.098749000 \\
\hline 6 & 9.994158000 & 2.041859000 & -4.401431000 \\
\hline 6 & 11.131424000 & 1.203009000 & -2.396269000 \\
\hline 1 & 12.071965000 & 1.447057000 & -2.939978000 \\
\hline 1 & 11.323269000 & 0.248960000 & -1.865269000 \\
\hline 6 & 10.826726000 & 2.289992000 & -1.376996000 \\
\hline 1 & 10.728574000 & 3.278753000 & -1.873365000 \\
\hline 1 & 11.685202000 & 2.382415000 & -0.673824000 \\
\hline 1 & 10.291930000 & 2.999374000 & -3.930569000 \\
\hline 1 & 10.768294000 & 1.834094000 & -5.175101000 \\
\hline 1 & 8.386878000 & 1.267773000 & -5.643960000 \\
\hline 1 & 8.748180000 & 2.987625000 & -5.885016000 \\
\hline 1 & 7.581846000 & 4.597607000 & -4.544747000 \\
\hline 1 & 8.503235000 & 4.024259000 & -3.105528000 \\
\hline 1 & 7.595405000 & 5.743057000 & -2.048142000 \\
\hline 1 & 6.317330000 & 6.296997000 & -3.148327000 \\
\hline 6 & 4.652553000 & 5.043282000 & 0.936061000 \\
\hline 6 & 3.532622000 & 4.151002000 & 0.424859000 \\
\hline 7 & 4.025623000 & 2.772988000 & 0.175498000 \\
\hline 6 & 2.958390000 & 1.961154000 & -0.421814000 \\
\hline 1 & 2.549764000 & 2.528165000 & -1.282423000 \\
\hline 1 & 3.124636000 & 4.537550000 & -0.532027000 \\
\hline 1 & 2.688102000 & 4.173858000 & 1.150617000 \\
\hline 1 & 4.967881000 & 4.691614000 & 1.938149000 \\
\hline
\end{tabular}




$\begin{array}{rrrr}1 & 4.275369000 & 6.080751000 & 1.079045000 \\ 1 & 5.092128000 & 4.661534000 & -4.387558000 \\ 1 & 4.314540000 & 4.120652000 & -2.854685000 \\ 1 & 3.019451000 & 2.851748000 & -4.115877000 \\ 1 & 3.795480000 & 2.915223000 & -5.710641000 \\ 1 & 4.175108000 & 0.448996000 & -5.683908000 \\ 1 & 2.464351000 & 0.882760000 & -5.543858000 \\ 1 & 1.856954000 & 1.387002000 & -3.064887000 \\ 1 & 1.259035000 & -0.239822000 & -3.451257000 \\ 1 & 2.486983000 & -1.177104000 & -1.439252000 \\ 1 & 1.323469000 & 0.082224000 & -0.988341000 \\ 1 & 9.472386000 & -0.401251000 & -4.848106000 \\ 1 & 11.120682000 & -0.628703000 & -4.229877000 \\ 1 & 9.957506000 & 3.233142000 & 1.031664000 \\ 1 & 6.202706000 & 2.947919000 & -5.806356000 \\ 1 & 6.208942000 & 1.236498000 & -5.245530000 \\ 1 & 5.350376000 & -1.256318000 & -5.238473000 \\ 1 & 4.992159000 & -2.859465000 & -4.557940000 \\ 1 & 7.371091000 & -2.781430000 & -3.589660000 \\ 1 & 2.113625000 & 1.828312000 & 0.300599000 \\ 1 & 9.276376000 & 4.065018000 & -0.393501000 \\ 1 & 5.527432000 & -1.964747000 & -2.380454000 \\ 1 & 7.979519000 & -1.513775000 & -1.601396000 \\ 1 & 7.770595000 & 2.195598000 & 1.329407000 \\ 1 & 4.272138000 & 2.355677000 & 1.087239000 \\ 1 & 3.777301000 & 0.104274000 & -0.119625000 \\ 1 & 9.685699000 & 1.174129000 & -0.088048000 \\ 8 & 6.452142000 & 1.246907000 & -1.369009000\end{array}$

\begin{tabular}{lrrr}
\multicolumn{4}{l}{$\left[\mathrm{TREN}_{3} \mathrm{Cu}^{\mathrm{II}} \mathrm{Cu}^{\mathrm{II}} \mathrm{Cu}^{\mathrm{II}}\left(\mu_{3}-\mathrm{O}\right)\right]-\mathrm{BP} 86 / \mathrm{def} 2-\mathrm{SVP}(\mathrm{C}, \mathrm{H}, \mathrm{O}, \mathrm{N}) / \mathrm{def} 2-\mathrm{TZVP}(\mathrm{Cu})$} \\
4,4 & & & \\
29 & 4.991974000 & 0.732780000 & -2.547108000 \\
7 & 3.364416000 & 0.084940000 & -3.778646000 \\
6 & 3.494433000 & -1.374536000 & -4.087621000 \\
1 & 3.085363000 & -1.950454000 & -3.234629000 \\
1 & 2.869935000 & -1.643707000 & -4.968500000 \\
6 & 4.939684000 & -1.769071000 & -4.323370000 \\
7 & 5.790180000 & -1.313320000 & -3.185936000 \\
7 & 5.093598000 & 2.496603000 & -3.997332000 \\
6 & 6.270367000 & 2.247922000 & -4.858375000 \\
7 & 7.541970000 & 2.472847000 & -4.131124000 \\
29 & 8.127298000 & 1.158401000 & -2.355872000 \\
29 & 6.168398000 & 3.068639000 & -0.751028000 \\
7 & 7.809573000 & 3.056339000 & 0.727388000 \\
6 & 9.181456000 & 3.107412000 & 0.190815000 \\
7 & 9.503235000 & 2.007546000 & -0.730333000 \\
7 & 8.158358000 & -1.045940000 & -2.527131000 \\
6 & 7.193381000 & -1.659967000 & -3.457056000 \\
1 & 7.436223000 & -1.315951000 & -4.481915000 \\
6 & 9.552001000 & -1.405002000 & -2.937855000 \\
1 & 10.182242000 & -1.440966000 & -2.028666000 \\
1 & 9.599552000 & -2.424449000 & -3.378832000 \\
6 & 10.076510000 & -0.380949000 & -3.940629000 \\
7 & 10.009477000 & 0.995510000 & -3.359258000 \\
7 & 3.456886000 & 0.658138000 & -0.959429000
\end{tabular}




\begin{tabular}{|c|c|c|c|}
\hline 6 & 2.294113000 & -0.080299000 & -1.546998000 \\
\hline 6 & 2.106150000 & 0.327203000 & -3.005934000 \\
\hline 6 & 3.432161000 & 0.895147000 & -5.031126000 \\
\hline 6 & 3.812251000 & 2.347635000 & -4.767722000 \\
\hline 6 & 5.158135000 & 3.888854000 & -3.494378000 \\
\hline 7 & 6.406410000 & 4.147162000 & -2.745325000 \\
\hline 7 & 5.842040000 & 5.036448000 & 0.034923000 \\
\hline 6 & 7.069103000 & 5.416226000 & 0.802160000 \\
\hline 6 & 7.566075000 & 4.230080000 & 1.623558000 \\
\hline 1 & 6.822838000 & 3.930018000 & 2.386920000 \\
\hline 1 & 8.481690000 & 4.515101000 & 2.186201000 \\
\hline 1 & 7.847884000 & 5.746420000 & 0.086556000 \\
\hline 1 & 6.865153000 & 6.289859000 & 1.460130000 \\
\hline 6 & 5.600324000 & 5.925512000 & -1.139444000 \\
\hline 1 & 4.532025000 & 5.839666000 & -1.422757000 \\
\hline 1 & 5.752081000 & 6.994164000 & -0.863670000 \\
\hline 6 & 6.495937000 & 5.587361000 & -2.325577000 \\
\hline 6 & 7.561578000 & 3.863118000 & -3.629591000 \\
\hline 6 & 8.671955000 & 2.227075000 & -5.090859000 \\
\hline 6 & 10.023304000 & 2.060775000 & -4.404950000 \\
\hline 6 & 11.135486000 & 1.187118000 & -2.390486000 \\
\hline 1 & 12.078290000 & 1.424421000 & -2.931149000 \\
\hline 1 & 11.315107000 & 0.226253000 & -1.869107000 \\
\hline 6 & 10.824376000 & 2.268200000 & -1.372722000 \\
\hline 1 & 10.777473000 & 3.269904000 & -1.848200000 \\
\hline 1 & 11.648455000 & 2.319192000 & -0.626627000 \\
\hline 1 & 10.337616000 & 3.009253000 & -3.926520000 \\
\hline 1 & 10.794590000 & 1.844729000 & -5.178058000 \\
\hline 1 & 8.414814000 & 1.310790000 & -5.660913000 \\
\hline 1 & 8.744287000 & 3.045514000 & -5.843959000 \\
\hline 1 & 7.552158000 & 4.577135000 & -4.495465000 \\
\hline 1 & 8.494454000 & 4.039840000 & -3.061843000 \\
\hline 1 & 7.558578000 & 5.782570000 & -2.076057000 \\
\hline 1 & 6.251243000 & 6.267679000 & -3.173623000 \\
\hline 6 & 4.656717000 & 5.040651000 & 0.950034000 \\
\hline 6 & 3.546300000 & 4.147445000 & 0.432035000 \\
\hline 7 & 4.077745000 & 2.785531000 & 0.136409000 \\
\hline 6 & 2.999232000 & 1.946778000 & -0.407843000 \\
\hline 1 & 2.503092000 & 2.513329000 & -1.221357000 \\
\hline 1 & 3.108016000 & 4.549100000 & -0.504640000 \\
\hline 1 & 2.717611000 & 4.120496000 & 1.174515000 \\
\hline 1 & 4.982692000 & 4.687040000 & 1.947242000 \\
\hline 1 & 4.283502000 & 6.077770000 & 1.098287000 \\
\hline 1 & 5.083376000 & 4.600381000 & -4.358770000 \\
\hline 1 & 4.287418000 & 4.069033000 & -2.836476000 \\
\hline 1 & 3.022627000 & 2.848546000 & -4.171357000 \\
\hline 1 & 3.858859000 & 2.895662000 & -5.736520000 \\
\hline 1 & 4.163500000 & 0.416862000 & -5.713792000 \\
\hline 1 & 2.457853000 & 0.867828000 & -5.569238000 \\
\hline 1 & 1.850174000 & 1.403217000 & -3.076006000 \\
\hline 1 & 1.253552000 & -0.225191000 & -3.459512000 \\
\hline 1 & 2.489422000 & -1.166851000 & -1.452353000 \\
\hline 1 & 1.357666000 & 0.106814000 & -0.977096000 \\
\hline 1 & 9.470191000 & -0.400319000 & -4.867268000 \\
\hline 1 & 11.117317000 & -0.628500000 & -4.245072000 \\
\hline
\end{tabular}




$\begin{array}{lrrr}1 & 9.915816000 & 3.132291000 & 1.033007000 \\ 1 & 6.231795000 & 2.920808000 & -5.755819000 \\ 1 & 6.250301000 & 1.204315000 & -5.222756000 \\ 1 & 5.339786000 & -1.305145000 & -5.248854000 \\ 1 & 5.000579000 & -2.869352000 & -4.476467000 \\ 1 & 7.321063000 & -2.769903000 & -3.455305000 \\ 1 & 2.221383000 & 1.767054000 & 0.373925000 \\ 1 & 9.302692000 & 4.060302000 & -0.362481000 \\ 1 & 5.494365000 & -1.839555000 & -2.346699000 \\ 1 & 7.986327000 & -1.418029000 & -1.580642000 \\ 1 & 7.706695000 & 2.193015000 & 1.281877000 \\ 1 & 4.373186000 & 2.368071000 & 1.034752000 \\ 1 & 3.850507000 & 0.092839000 & -0.191869000 \\ 1 & 9.598273000 & 1.144987000 & -0.168339000 \\ 8 & 6.450609000 & 1.284085000 & -1.417582000\end{array}$

\begin{tabular}{lrrr}
\multicolumn{4}{l}{ TREN } \\
\hline 3,2 & $\left.\mathrm{Cu}^{\mathrm{I}} \mathrm{Cu}^{\mathrm{I}} \mathrm{Cu}^{\mathrm{II}}\left(\mu_{3}-\mathrm{OH}\right)\right]-\mathrm{BP} 86 / \mathrm{def} 2-\mathrm{TZVP}(\mathrm{TD}-\mathrm{DFT})$ \\
29 & 9.863709000 & -0.255723000 & 10.292554000 \\
6 & 10.996198000 & 1.975354000 & 12.070077000 \\
1 & 11.009247000 & 2.886877000 & 12.700143000 \\
1 & 12.011053000 & 1.879665000 & 11.655274000 \\
6 & 8.394522000 & -1.357951000 & 12.903464000 \\
1 & 7.912575000 & -2.129739000 & 13.534778000 \\
1 & 8.092595000 & -0.389376000 & 13.329232000 \\
7 & 7.892816000 & -1.394897000 & 11.512450000 \\
6 & 9.905498000 & -1.535335000 & 13.002691000 \\
1 & 10.196914000 & -1.512594000 & 14.068425000 \\
1 & 10.188046000 & -2.529058000 & 12.628443000 \\
7 & 10.678965000 & -0.518770000 & 12.233431000 \\
7 & 11.664062000 & -1.539717000 & 9.645162000 \\
7 & 12.065839000 & -0.142993000 & 7.738207000 \\
7 & 10.868347000 & -2.238593000 & 7.454234000 \\
6 & 10.681852000 & 0.782202000 & 12.966313000 \\
1 & 11.415535000 & 0.755193000 & 13.792111000 \\
1 & 9.700541000 & 0.909767000 & 13.440207000 \\
6 & 11.427041000 & -2.684149000 & 8.746803000 \\
1 & 10.721391000 & -3.370771000 & 9.232890000 \\
1 & 12.383882000 & -3.230268000 & 8.573150000 \\
6 & 7.869488000 & -2.766267000 & 10.993029000 \\
1 & 7.216418000 & -3.409952000 & 11.633127000 \\
1 & 8.883266000 & -3.188673000 & 11.014811000 \\
6 & 12.082067000 & -0.995383000 & 12.046313000 \\
1 & 12.475399000 & -1.422054000 & 12.986130000 \\
1 & 12.708463000 & -0.122883000 & 11.817099000 \\
6 & 11.802554000 & -1.255963000 & 6.841092000 \\
1 & 11.341095000 & -0.880102000 & 5.920946000 \\
1 & 12.749456000 & -1.783781000 & 6.563662000 \\
6 & 12.638072000 & -0.643691000 & 8.975244000 \\
1 & 12.868770000 & 0.204208000 & 9.632619000 \\
1 & 13.587265000 & -1.211572000 & 8.803081000 \\
6 & 12.363314000 & 1.645696000 & 5.957453000 \\
1 & 12.087599000 & 0.954393000 & 5.150228000 \\
1 & 13.178325000 & 2.273903000 & 5.537934000 \\
6 & 12.204642000 & -2.034433000 & 10.937301000
\end{tabular}




\begin{tabular}{|c|c|c|c|}
\hline 1 & 13.263140000 & -2.338398000 & 10.844876000 \\
\hline 1 & 11.645727000 & -2.944036000 & 11.203832000 \\
\hline 6 & 12.966250000 & 0.856304000 & 7.122064000 \\
\hline 1 & 13.266756000 & 1.545121000 & 7.925146000 \\
\hline 1 & 13.902905000 & 0.384603000 & 6.759948000 \\
\hline 29 & 8.702366000 & -1.652336000 & 7.771688000 \\
\hline 6 & 10.739917000 & -3.388253000 & 6.516339000 \\
\hline 1 & 11.649199000 & -4.017716000 & 6.522337000 \\
\hline 1 & 10.668836000 & -2.964932000 & 5.503717000 \\
\hline 6 & 7.394857000 & -4.168657000 & 9.101675000 \\
\hline 1 & 6.604674000 & -4.779748000 & 9.579532000 \\
\hline 1 & 8.352281000 & -4.618290000 & 9.405667000 \\
\hline 7 & 7.388331000 & -2.776360000 & 9.604639000 \\
\hline 6 & 7.218453000 & -4.253454000 & 7.590769000 \\
\hline 1 & 7.220178000 & -5.315876000 & 7.287668000 \\
\hline 1 & 6.235404000 & -3.853949000 & 7.310064000 \\
\hline 7 & 8.252059000 & -3.494233000 & 6.832302000 \\
\hline 7 & 7.214861000 & -0.850763000 & 5.830471000 \\
\hline 7 & 8.609598000 & 1.040664000 & 5.406815000 \\
\hline 7 & 6.541636000 & 1.340543000 & 6.642776000 \\
\hline 6 & 9.529505000 & -4.267559000 & 6.806790000 \\
\hline 1 & 9.481000000 & -5.071846000 & 6.050631000 \\
\hline 1 & 9.646750000 & -4.768952000 & 7.776325000 \\
\hline 6 & 6.082530000 & 0.039031000 & 6.102565000 \\
\hline 1 & 5.428087000 & -0.446095000 & 6.840381000 \\
\hline 1 & 5.487319000 & 0.217436000 & 5.173478000 \\
\hline 6 & 6.024859000 & -2.225177000 & 9.583361000 \\
\hline 1 & 5.342101000 & -2.879762000 & 10.181194000 \\
\hline 1 & 5.651344000 & -2.206024000 & 8.550520000 \\
\hline 6 & 7.774170000 & -3.256183000 & 5.436355000 \\
\hline 1 & 7.355140000 & -4.187551000 & 5.015129000 \\
\hline 1 & 8.648212000 & -3.005856000 & 4.820058000 \\
\hline 6 & 7.504236000 & 1.941928000 & 5.681483000 \\
\hline 1 & 7.888163000 & 2.869412000 & 6.122072000 \\
\hline 1 & 6.956656000 & 2.207012000 & 4.741098000 \\
\hline 6 & 8.089357000 & -0.193984000 & 4.843498000 \\
\hline 1 & 8.930023000 & -0.856679000 & 4.598821000 \\
\hline 1 & 7.514700000 & -0.012626000 & 3.897536000 \\
\hline 6 & 10.407617000 & 2.797693000 & 5.103654000 \\
\hline 1 & 9.729009000 & 3.619106000 & 5.368236000 \\
\hline 1 & 11.056322000 & 3.203153000 & 4.297868000 \\
\hline 6 & 6.726711000 & -2.150674000 & 5.329262000 \\
\hline 1 & 6.395559000 & -2.088928000 & 4.274503000 \\
\hline 1 & 5.829874000 & -2.419329000 & 5.908369000 \\
\hline 6 & 9.601100000 & 1.648027000 & 4.497327000 \\
\hline 1 & 10.276769000 & 0.838359000 & 4.183313000 \\
\hline 1 & 9.126301000 & 2.022479000 & 3.566691000 \\
\hline 29 & 7.158111000 & 1.128257000 & 8.846880000 \\
\hline 8 & 8.851378000 & 0.136057000 & 8.622385000 \\
\hline 6 & 5.387653000 & 2.271853000 & 6.762782000 \\
\hline 1 & 4.771943000 & 2.267856000 & 5.843496000 \\
\hline 1 & 5.801486000 & 3.287524000 & 6.849266000 \\
\hline 6 & 4.613268000 & -0.354338000 & 10.070969000 \\
\hline 1 & 3.984521000 & -0.847535000 & 10.838310000 \\
\hline 1 & 4.188648000 & -0.648092000 & 9.098945000 \\
\hline
\end{tabular}




$\begin{array}{rrrr}7 & 6.006374000 & -0.852643000 & 10.104899000 \\ 6 & 4.505395000 & 1.153132000 & 10.265351000 \\ 1 & 3.437766000 & 1.437399000 & 10.267220000 \\ 1 & 4.899720000 & 1.428169000 & 11.252638000 \\ 7 & 5.248070000 & 1.941203000 & 9.241585000 \\ 7 & 7.869196000 & 2.897880000 & 10.228261000 \\ 7 & 9.777036000 & 3.353388000 & 8.859463000 \\ 7 & 10.074835000 & 2.120060000 & 10.919291000 \\ 6 & 4.490892000 & 1.963103000 & 7.955470000 \\ 1 & 3.675900000 & 2.707542000 & 7.998122000 \\ 1 & 4.005410000 & 0.987623000 & 7.826170000 \\ 6 & 8.767107000 & 2.621324000 & 11.368701000 \\ 1 & 8.286735000 & 1.864398000 & 12.004481000 \\ 1 & 8.899749000 & 3.552346000 & 11.972786000 \\ 6 & 6.524587000 & -0.862005000 & 11.479286000 \\ 1 & 5.855095000 & -1.468687000 & 12.139473000 \\ 1 & 6.541944000 & 0.163571000 & 11.872634000 \\ 7 & 11.178739000 & 2.441302000 & 6.302162000 \\ 6 & 5.459492000 & 3.336250000 & 9.732359000 \\ 1 & 4.530342000 & 3.733246000 & 10.178285000 \\ 1 & 5.682589000 & 3.969852000 & 8.863544000 \\ 6 & 10.672572000 & 3.089564000 & 9.975105000 \\ 1 & 11.608257000 & 2.660712000 & 9.597428000 \\ 1 & 10.924299000 & 4.037686000 & 10.517402000 \\ 6 & 8.535482000 & 3.903527000 & 9.367139000 \\ 1 & 7.879577000 & 4.155901000 & 8.523339000 \\ 1 & 8.698406000 & 4.837310000 & 9.964318000 \\ 6 & 11.542249000 & 3.638522000 & 7.071755000 \\ 1 & 12.354632000 & 3.369975000 & 7.759526000 \\ 1 & 11.960118000 & 4.438051000 & 6.423372000 \\ 6 & 6.586956000 & 3.429677000 & 10.753219000 \\ 1 & 6.688198000 & 4.480456000 & 11.081520000 \\ 1 & 6.330941000 & 2.853114000 & 11.655149000 \\ 6 & 10.388442000 & 4.256563000 & 7.865101000 \\ 1 & 9.584375000 & 4.565586000 & 7.180776000 \\ 1 & 10.761834000 & 5.189483000 & 8.335733000 \\ 1 & 9.434888000 & 0.686981000 & 8.049087000\end{array}$

\section{[TREN $\left.{ }_{4} \mathrm{Cu}^{\mathrm{I}} \mathrm{Cu}^{\mathrm{II}} \mathrm{Cu}^{\mathrm{II}}\left(\mu_{3}-\mathrm{OH}\right)\right]-\mathrm{BP} 86 / \mathrm{def} 2-\mathrm{TZVP}(\mathrm{TD}-\mathrm{DFT})$}

$\begin{array}{lrrr}4,3 & & & \\ 29 & 11.335532000 & 5.561258000 & 4.697933000 \\ 29 & 8.965119000 & 7.918370000 & 4.633196000 \\ 29 & 10.784921000 & 7.414099000 & 7.401208000 \\ 8 & 10.730231000 & 7.342440000 & 5.391752000 \\ 7 & 9.601658000 & 4.305787000 & 5.913186000 \\ 7 & 7.029813000 & 8.308150000 & 3.899175000 \\ 7 & 13.401160000 & 5.559503000 & 5.643785000 \\ 7 & 9.568134000 & 7.902492000 & 2.447341000 \\ 7 & 8.587901000 & 9.829380000 & 5.860954000 \\ 7 & 13.898996000 & 7.892185000 & 6.169954000 \\ 7 & 10.817242000 & 10.653486000 & 5.504129000 \\ 7 & 11.824082000 & 3.613733000 & 4.072882000 \\ 7 & 8.827917000 & 5.861894000 & 7.608814000 \\ 7 & 12.843888000 & 6.511488000 & 7.830235000 \\ 7 & 12.003851000 & 8.060406000 & 2.439214000\end{array}$




\begin{tabular}{|c|c|c|c|}
\hline 7 & 10.259138000 & 9.604626000 & 7.637565000 \\
\hline 7 & 7.809035000 & 5.863488000 & 5.401357000 \\
\hline 7 & 10.593006000 & 7.343613000 & 9.503238000 \\
\hline 7 & 13.484446000 & 10.128058000 & 4.116902000 \\
\hline 7 & 10.964562000 & 5.887885000 & 2.440322000 \\
\hline 6 & 8.832687000 & 9.837002000 & 7.319098000 \\
\hline 6 & 14.318335000 & 6.717565000 & 5.422672000 \\
\hline 6 & 13.302045000 & 5.311117000 & 7.100235000 \\
\hline 6 & 13.849898000 & 7.579865000 & 7.586690000 \\
\hline 6 & 9.703921000 & 6.505471000 & 1.974771000 \\
\hline 6 & 10.762776000 & 8.676379000 & 1.997320000 \\
\hline 6 & 6.025334000 & 7.408828000 & 4.542013000 \\
\hline 6 & 8.337969000 & 4.504391000 & 5.181463000 \\
\hline 6 & 12.085941000 & 6.710405000 & 1.912499000 \\
\hline 6 & 7.577771000 & 6.036620000 & 6.846988000 \\
\hline 6 & 9.335141000 & 4.505255000 & 7.350433000 \\
\hline 6 & 8.505515000 & 6.025135000 & 9.054182000 \\
\hline 6 & 12.080056000 & 3.659203000 & 2.600672000 \\
\hline 6 & 13.183638000 & 8.840751000 & 1.981640000 \\
\hline 6 & 11.082829000 & 10.633492000 & 6.933827000 \\
\hline 6 & 9.409891000 & 10.922269000 & 5.275417000 \\
\hline 6 & 9.738224000 & 6.194726000 & 9.926836000 \\
\hline 6 & 14.798067000 & 9.626855000 & 4.537536000 \\
\hline 6 & 11.045542000 & 4.507373000 & 1.875074000 \\
\hline 6 & 7.137558000 & 10.102151000 & 5.628197000 \\
\hline 6 & 14.026838000 & 4.371006000 & 4.977902000 \\
\hline 6 & 10.082301000 & 2.906945000 & 5.732732000 \\
\hline 6 & 8.372672000 & 8.539775000 & 1.806574000 \\
\hline 6 & 6.712916000 & 9.735270000 & 4.213219000 \\
\hline 6 & 10.708835000 & 2.665513000 & 4.368416000 \\
\hline 6 & 13.058429000 & 3.210634000 & 4.812072000 \\
\hline 6 & 14.821937000 & 9.034936000 & 5.946933000 \\
\hline 6 & 9.985465000 & 8.636213000 & 9.944026000 \\
\hline 6 & 13.356230000 & 10.198859000 & 2.657310000 \\
\hline 6 & 10.481005000 & 9.803457000 & 9.106326000 \\
\hline 6 & 12.792143000 & 6.181799000 & 9.287073000 \\
\hline 6 & 11.635329000 & 11.684212000 & 4.816715000 \\
\hline 6 & 11.969865000 & 7.196163000 & 10.067759000 \\
\hline 6 & 6.517466000 & 5.974820000 & 4.664162000 \\
\hline 6 & 13.136111000 & 11.396799000 & 4.766973000 \\
\hline 6 & 7.058219000 & 8.087045000 & 2.421944000 \\
\hline 1 & 8.514891000 & 10.817908000 & 7.739130000 \\
\hline 1 & 8.220684000 & 9.053524000 & 7.785759000 \\
\hline 1 & 15.351169000 & 6.402646000 & 5.708833000 \\
\hline 1 & 14.315674000 & 6.947249000 & 4.350434000 \\
\hline 1 & 12.596182000 & 4.490998000 & 7.285384000 \\
\hline 1 & 14.297583000 & 5.003360000 & 7.490710000 \\
\hline 1 & 14.835861000 & 7.234382000 & 7.982888000 \\
\hline 1 & 13.569739000 & 8.484940000 & 8.142602000 \\
\hline 1 & 8.860627000 & 5.910864000 & 2.350337000 \\
\hline 1 & 9.673569000 & 6.485746000 & 0.861765000 \\
\hline 1 & 10.727366000 & 8.757807000 & 0.883665000 \\
\hline 1 & 10.685612000 & 9.688059000 & 2.412661000 \\
\hline 1 & 5.787257000 & 7.817501000 & 5.531771000 \\
\hline 1 & 5.082215000 & 7.418837000 & 3.968611000 \\
\hline
\end{tabular}




\begin{tabular}{|c|c|c|c|}
\hline 1 & 8.511656000 & 4.363880000 & 4.107223000 \\
\hline 1 & 7.588524000 & 3.745599000 & 5.508546000 \\
\hline 1 & 12.043824000 & 6.687767000 & 0.796576000 \\
\hline 1 & 13.041290000 & 6.265379000 & 2.220610000 \\
\hline 1 & 6.809579000 & 5.306759000 & 7.197120000 \\
\hline 1 & 7.193915000 & 7.047363000 & 7.038135000 \\
\hline 1 & 8.597280000 & 3.748676000 & 7.708946000 \\
\hline 1 & 10.271630000 & 4.350479000 & 7.900881000 \\
\hline 1 & 7.850100000 & 6.903510000 & 9.140753000 \\
\hline 1 & 7.918495000 & 5.168319000 & 9.435427000 \\
\hline 1 & 13.086689000 & 4.066012000 & 2.438914000 \\
\hline 1 & 12.084114000 & 2.640194000 & 2.176174000 \\
\hline 1 & 14.067532000 & 8.212812000 & 2.168207000 \\
\hline 1 & 13.153162000 & 9.004748000 & 0.886060000 \\
\hline 1 & 12.138306000 & 10.390408000 & 7.106983000 \\
\hline 1 & 10.872417000 & 11.626756000 & 7.399653000 \\
\hline 1 & 9.228673000 & 10.980199000 & 4.194583000 \\
\hline 1 & 9.081751000 & 11.890768000 & 5.726309000 \\
\hline 1 & 10.352229000 & 5.285700000 & 9.904579000 \\
\hline 1 & 9.419195000 & 6.323458000 & 10.976024000 \\
\hline 1 & 15.135178000 & 8.874194000 & 3.811287000 \\
\hline 1 & 15.573156000 & 10.420366000 & 4.509497000 \\
\hline 1 & 10.046680000 & 4.052990000 & 1.951180000 \\
\hline 1 & 11.288508000 & 4.532363000 & 0.798059000 \\
\hline 1 & 6.568520000 & 9.518445000 & 6.366143000 \\
\hline 1 & 6.894262000 & 11.162363000 & 5.817872000 \\
\hline 1 & 14.396504000 & 4.709210000 & 3.999400000 \\
\hline 1 & 14.913033000 & 4.026151000 & 5.539297000 \\
\hline 1 & 10.813615000 & 2.711052000 & 6.530863000 \\
\hline 1 & 9.264050000 & 2.178391000 & 5.881825000 \\
\hline 1 & 8.495408000 & 9.627179000 & 1.917568000 \\
\hline 1 & 8.353116000 & 8.339270000 & 0.720454000 \\
\hline 1 & 7.225948000 & 10.369979000 & 3.479735000 \\
\hline 1 & 5.633189000 & 9.927657000 & 4.091020000 \\
\hline 1 & 9.953885000 & 2.764657000 & 3.577114000 \\
\hline 1 & 11.069051000 & 1.623228000 & 4.316679000 \\
\hline 1 & 12.757884000 & 2.818857000 & 5.792964000 \\
\hline 1 & 13.568807000 & 2.381607000 & 4.292760000 \\
\hline 1 & 14.546663000 & 9.805766000 & 6.682281000 \\
\hline 1 & 15.868821000 & 8.753437000 & 6.179382000 \\
\hline 1 & 8.893964000 & 8.546432000 & 9.875441000 \\
\hline 1 & 10.212295000 & 8.826539000 & 11.006903000 \\
\hline 1 & 12.502164000 & 10.845663000 & 2.412754000 \\
\hline 1 & 14.233613000 & 10.689342000 & 2.186552000 \\
\hline 1 & 11.561902000 & 9.946232000 & 9.247141000 \\
\hline 1 & 9.997378000 & 10.732914000 & 9.455837000 \\
\hline 1 & 12.361262000 & 5.175022000 & 9.385649000 \\
\hline 1 & 13.806751000 & 6.125678000 & 9.719026000 \\
\hline 1 & 11.234816000 & 11.770676000 & 3.795318000 \\
\hline 1 & 11.496337000 & 12.681731000 & 5.279522000 \\
\hline 1 & 12.453938000 & 8.181040000 & 10.047821000 \\
\hline 1 & 11.921870000 & 6.893481000 & 11.127633000 \\
\hline 1 & 6.670163000 & 5.536826000 & 3.666579000 \\
\hline 1 & 5.726963000 & 5.368833000 & 5.144445000 \\
\hline 1 & 13.550766000 & 11.393785000 & 5.784266000 \\
\hline
\end{tabular}




$\begin{array}{lrrr}1 & 13.612618000 & 12.264046000 & 4.265301000 \\ 1 & 6.893461000 & 7.018939000 & 2.230208000 \\ 1 & 6.223248000 & 8.618437000 & 1.933931000 \\ 1 & 11.389742000 & 8.002306000 & 5.060312000\end{array}$

\section{Reference}

(1) Yakelis, N. A.; Bergman, R. G. Safe Preparation and Purification of Sodium Tetrakis[(3,5-Trifluoromethyl) Phenyl]Borate $\left(\mathrm{NaBArF}_{24}\right)$ : Reliable and Sensitive Analysis of Water in Solutions of Fluorinated Tetraarylborates. Organometallics 2005, $24,3579$.

(2) Stoll, S.; Schweiger, A. EasySpin, a Comprehensive Software Package for Spectral Simulation and Analysis in EPR. J. Magn. Reson. 2006, 178, 42.

(3) Sequoia, E.; Laboratoire, O. N.; Organique, P.; Gabriel, S. General Expression of the linear Potential Sweep voltammogram in the Case of diffusionless Electrochemical Systems. 1979, 101, 19.

(4) Sivasankaran, U.; Vikraman, A. E.; Thomas, D. Nanomolar Level Determination of Octyl Gallate in Fats and Oils. Food Anal. Methods 2016, 2115.

(5) Nicholson, R. S. Theory and Application of Cyclic Voltammetry for Measurement of Electrode Reaction Kinetics. Anal. Chem. 1965, 37, 1351.

(6) Lavagnini, I.; Antiochia, R.; Magno, F. An Extended Method for the Practical Evaluation of the Standard Rate Constant from Cyclic Voltammetric Data. Electroanalysis 2004, 16, 505.

(7) Gennari, M.; Pøcaut, J.; Debeer, S.; Neese, F.; Collomb, M.; Duboc, C. A Fully Delocalized Mixed-Valence Bis- $\mu$-(Thiolato) Dicopper. Angew. Chem. Int. Ed. 2011, 50, 5662 .

(8) Weaver, M. J. An Alternative Approach to the Intercomparison of Electron-Transfer Reactivities at Metal Surfaces and in Homogeneous Solution1. J. Phys. Chem. 1990, 94, 8608.

(9) Neese, F. Software Update: The ORCA Program System, Version 4.0. Wiley Interdiscip. Rev. Comput. Mol. Sci. 2018, 8, 4.

(10) Viktor N. Staroverov and Gustavo E. Scuseria. Comparative Assessment of a New Nonempirical Density Functional: Molecules and Hydrogen-Bonded Complexes. $J$. Chem. Phys. 2004, 119, 12129.

(11) Marenich, A. V; Cramer, C. J.; Truhlar, D. G. Universal Solvation Model Based on Solute Electron Density and on a Continuum Model of the Solvent Defined by the Bulk Dielectric Constant and Atomic Surface Tensions. J. Phys. Chem. B 2009, 113, 6378.

(12) Johnson, E. R.; Becke, A. D. A Post-Hartree-Fock Model of Intermolecular Interactions: Inclusion of Higher-Order Corrections. J. Chem. Phys. 2006, 124, 174104.

(13) Grimme, S.; Ehrlich, S.; Goerigk, L. Effect of the Damping Function in Dispersion Corrected Density Functional Theory. J. Comput. Chem. 2011, 32, 1456.

(14) Koepke, S. J.; Light, K. M.; Vannatta, P. E.; Wiley, K. M.; Kieber-Emmons, M. T. Electrocatalytic Water Oxidation by a Homogeneous Copper Catalyst Disfavors Single-Site Mechanisms. J. Am. Chem. Soc. 2017, 139, 8586. 